
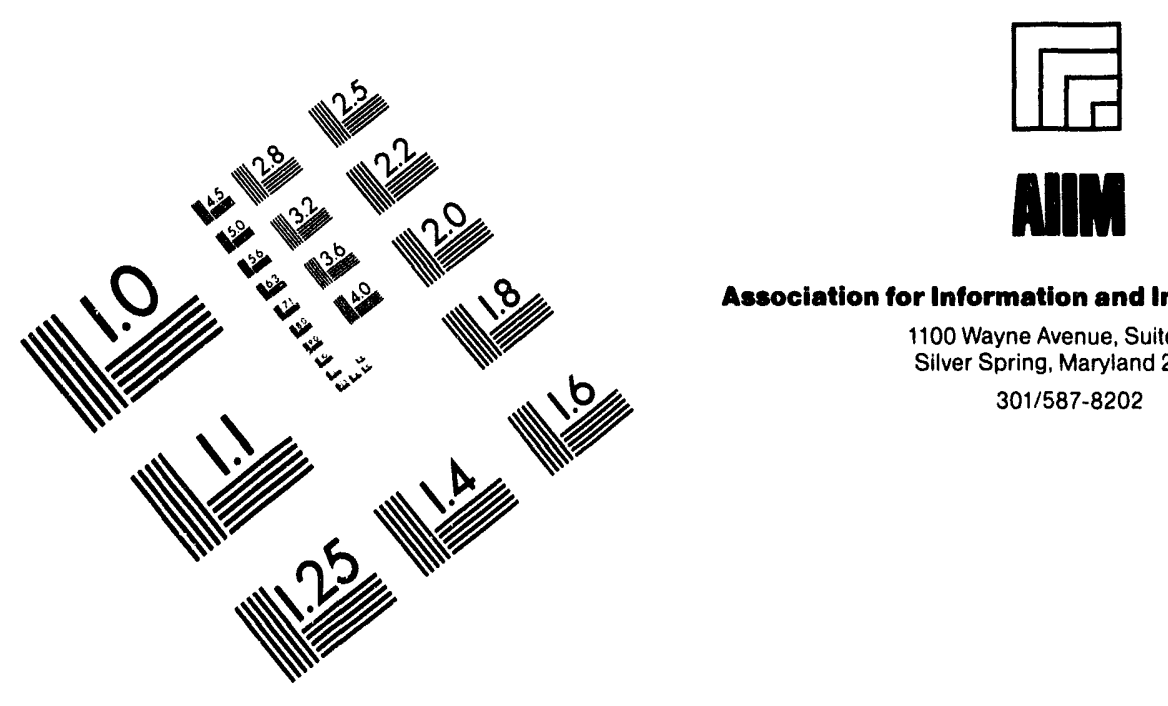

Association for Information and Image Management

1100 Wayne Avenue, Suite 1100

Silver Spring, Maryland 20910

301/587-8202

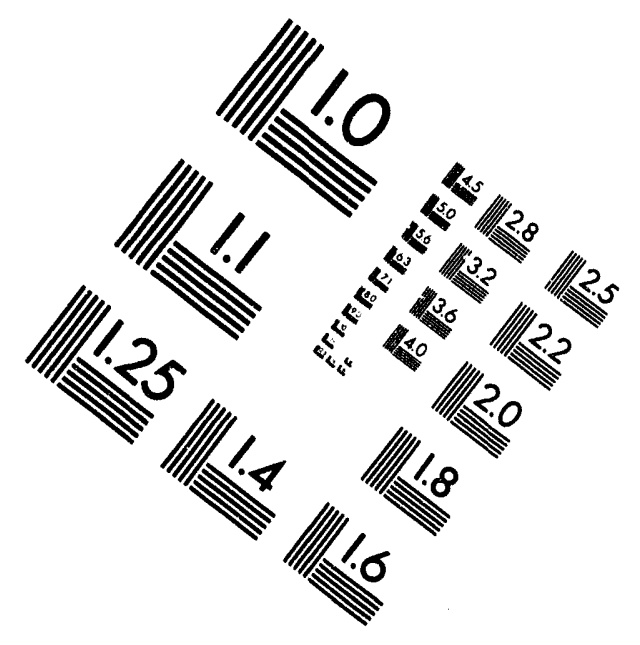

Centimeter

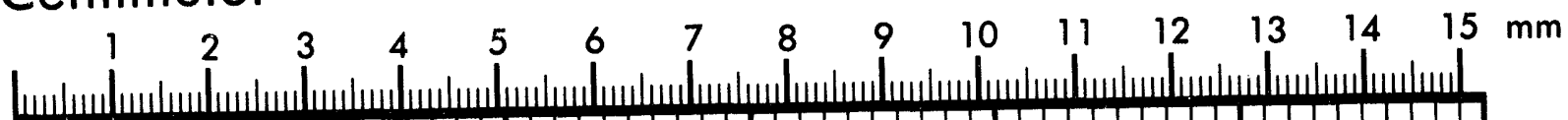

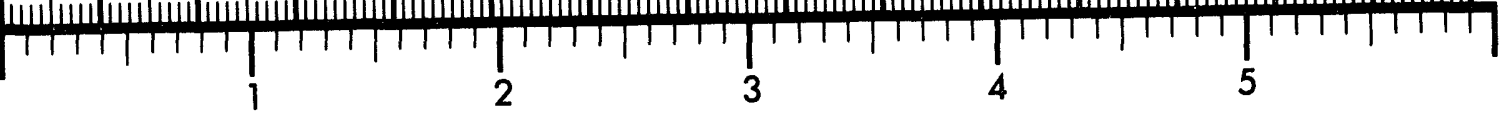
Inches
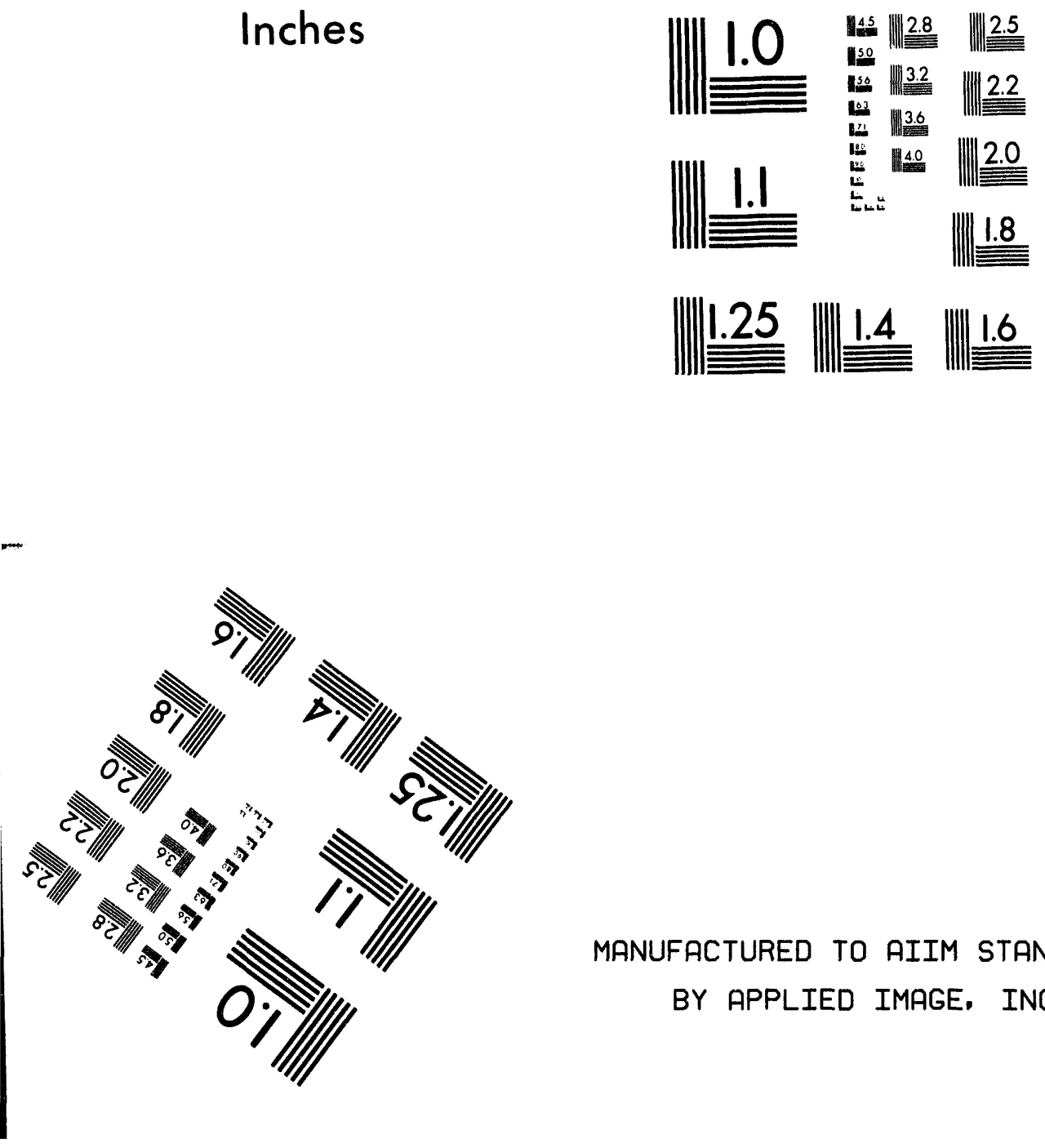

MANUFACTURED TO AIIM STANDARDS BY APPLIED IMAGE, INC.

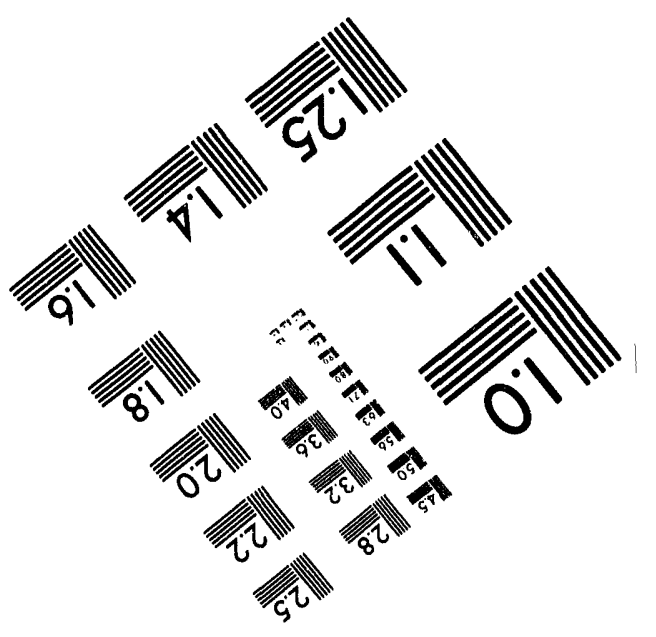



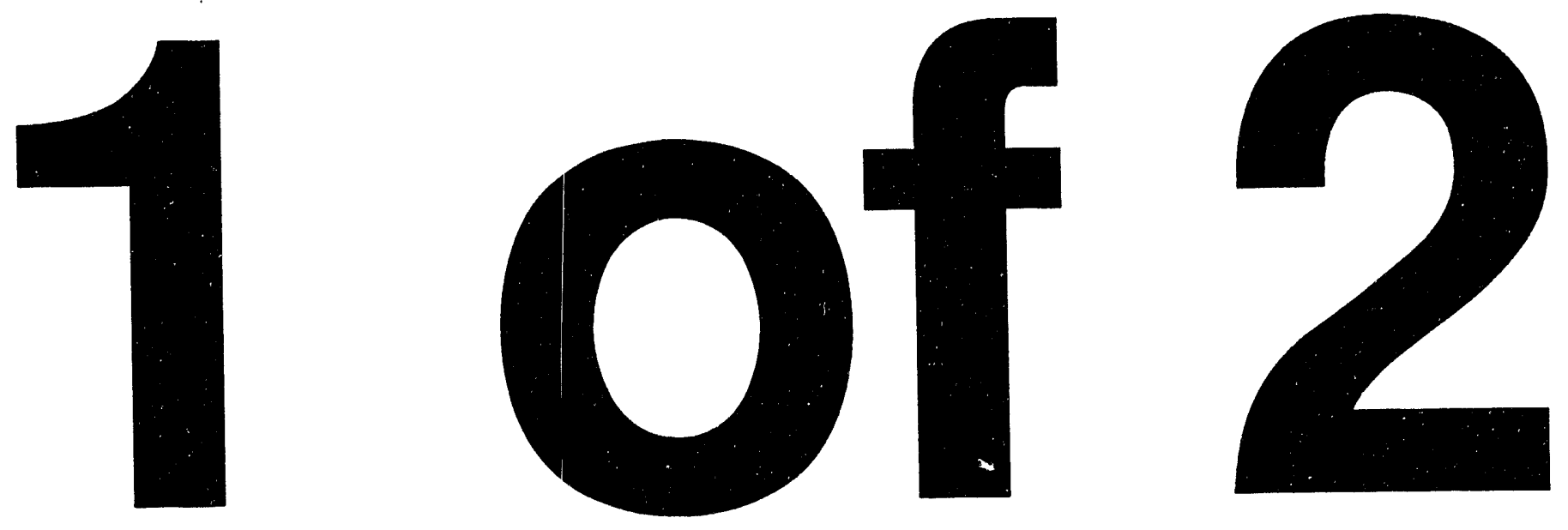
ORNL/TM-12759

\title{
FINAL WASTE FORMS PROJECT: PERFORMANCE CRITERIA FOR PHASE I TREATABILITY STUDIES
}

\author{
T. M. Gilliam \\ Chemical Technology Division \\ Oak Ridge National Laboratory \\ D. A. Hutchins \\ Waste Management Organization \\ Martin Marietta Energy Systems, Inc. \\ P. Chodak III \\ Massachusetts Institute of Technology
}

Date Published-June 1994

\author{
Prepared by \\ OAK RIDGE NATIONAL LABORATORY \\ Oak Ridge, Tennessee 37831-6285 \\ managed by \\ MARTIN MARIETTA ENERGY SYSTEMS, INC. \\ for the \\ U.S. DEPARTMENT OF ENERGY \\ under contract DE-AC05-84OR21400
}




\section{CONTENTS}

TABLES $\ldots \ldots \ldots \ldots \ldots \ldots \ldots \ldots \ldots \ldots \ldots \ldots \ldots \ldots \ldots \ldots$

ACRONYMS $\ldots \ldots \ldots \ldots \ldots \ldots \ldots \ldots \ldots \ldots \ldots \ldots \ldots \ldots \ldots \ldots$

PREFACE $\ldots \ldots \ldots \ldots \ldots \ldots \ldots \ldots \ldots \ldots \ldots \ldots \ldots \ldots \ldots \ldots \ldots \ldots \ldots \ldots \ldots \ldots$

ABSTRACT $\ldots \ldots \ldots \ldots \ldots \ldots \ldots \ldots \ldots \ldots \ldots \ldots \ldots \ldots \ldots \ldots \ldots \ldots$

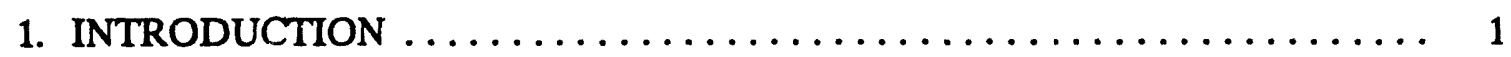

2. RATIONALE FOR SELECTION OF PERFORMANCE CRITERIA ...... 3

3. RESOURCE CONVERSATION AND RECOVERY ACT AND SUBSEQUENT REAUTHORIZATION AND AMENDMENTS $\ldots \ldots \ldots \ldots \ldots 4$

3.1 SPENT SOLVENTS AND DIOXIN WASTES $\ldots \ldots \ldots \ldots \ldots \ldots \ldots \ldots .5$

3.2 CALIFORNIA LIST WASTES $\ldots \ldots \ldots \ldots \ldots \ldots \ldots \ldots \ldots \ldots \ldots$

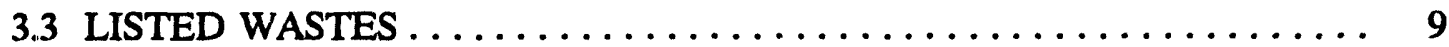

3.3.1 Treatment Standards . . . . . . . . . . . . . . . . . . 9

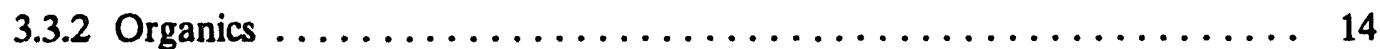

3.4 CHARACTERISTIC WASTES $\ldots \ldots \ldots \ldots \ldots \ldots \ldots \ldots \ldots \ldots \ldots \ldots \ldots$

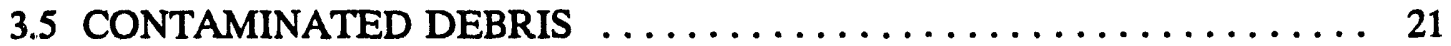

3.5.1 Debris Containing Listed Waste with Specified Treatment

Technologies as Treatment Standards ................. 24

3.5.2 Debris Containing Listed Wastes with Specified

Concentration-Based Treatment Standards ............... 24

3.5.3 Debris Contaminated with Characteristic Waste .............. 25

3.5.4 Impact on Phase I Performance Criteria $\ldots \ldots \ldots \ldots \ldots \ldots \ldots \ldots$

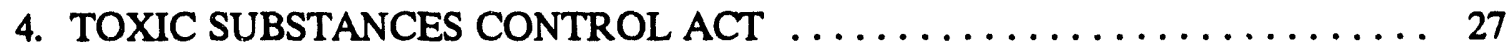

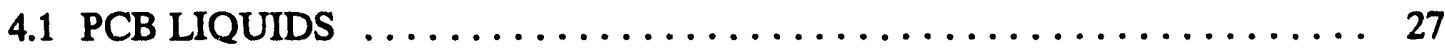

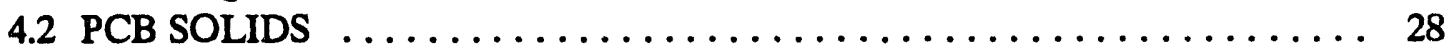

4.3 PCB SPILI CLEANUP POLICY REQUIREMENTS . . . . . . . . . 28

4.4 PCB-CONTAMINATED DEBRIS $\ldots \ldots \ldots \ldots \ldots \ldots \ldots \ldots \ldots \ldots \ldots$

4.5 IMPACT ON PERFORMANCE CRITERIA $\ldots \ldots \ldots \ldots \ldots \ldots \ldots \ldots$.

5. NUCLEAR REGULATORY COMMISSION REGULATIONS . . . . . . 31

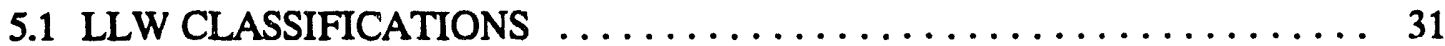

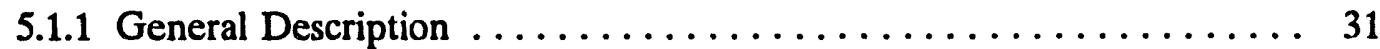

5.1.2 Technical Definitions (10 CFR 61.55) ............... 33

5.2 REQUIRED LLW WASTE FORM CHARACTERISTICS $\ldots \ldots \ldots \ldots \ldots . . \ldots$

5.2.1 Requirements for All LLW Classifications ............. 35

5.2 .2 Wast Form Stability Requirements ................ 36

5.2.3 Requirements Particular to Cement Waste Forms ............ 38

5.2.4 Summary of NRC Waste Form Requirements ............. 41

5.3 IMPACT ON PHASE I WASTE FORM PERFORMANCE CRITERIA . . 41 


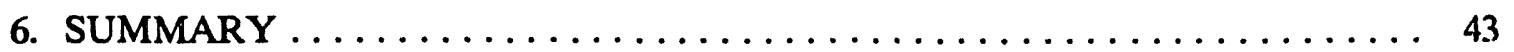

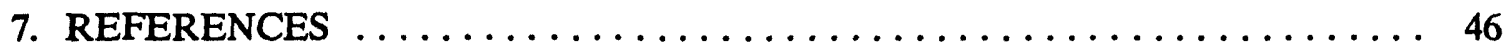

8. ACKNOWLEDGMENTS $\ldots \ldots \ldots \ldots \ldots \ldots \ldots \ldots \ldots \ldots \ldots \ldots$

Appendix A. TREATMENT STANDARDS FOR LISTED WASTES $\ldots \ldots \ldots \ldots$

Appendix B. TECHNOLOGY CODES USED IN APPENDIX A $\ldots \ldots \ldots \ldots \ldots$

Appendix C. TREATMENT STANDARDS FOR DEBRIS $\ldots \ldots \ldots \ldots \ldots \ldots \ldots$ 


\section{TABLES}

1 Treatment standards for spent solvent wastes (nonwastewater) $\ldots \ldots \ldots \ldots$

2 Treatment standards for dioxin wastes (nonwastewater) $\ldots \ldots \ldots \ldots \ldots$

3 Treatment standards for listed wastes (nonwastewater) based on stabilization as BDAT $\ldots \ldots \ldots \ldots \ldots \ldots \ldots \ldots \ldots \ldots \ldots \ldots$

4 TCLP treatment standards based on stabilization as BDAT for treatment residues of listed wastes (nonwastewater) $\ldots \ldots \ldots \ldots \ldots \ldots \ldots \ldots$

5 Treatment standards for characteristic wastes (nonwastewater) $\ldots \ldots \ldots \ldots \ldots$

6 TCLP concentration standards for characteristic wastes

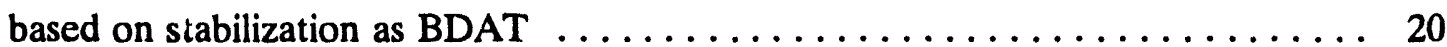

7 NRC radionuclide concentrations used to classify low-level radioactive wastes: long-lived radionuclides

8 NRC radionuclide concentrations used to classify low-level radioactive wastes: short-lived radionuclides

9 Known problematic wastes $\ldots \ldots \ldots \ldots \ldots \ldots \ldots \ldots \ldots \ldots \ldots \ldots \ldots$

10 Stability criterion vs test procedures $\ldots \ldots \ldots \ldots \ldots \ldots \ldots \ldots \ldots \ldots \ldots \ldots$

11 Comparison of EPA and NRC waste form evaluation methods . . . . . . . 44 


\section{ACRONYMS}

\begin{tabular}{ll} 
ANS & American Nuclear Society \\
ANSI & American National Standards Institute \\
ASTM & American Society of Testing and Materials \\
BDAT & best demonstrated available technology \\
CERCLA & Comprehensive Environmental Response, Compensation, and Liability Act \\
CFR & Code of Federal Regulations \\
CCW & constituent concentrations in the waste \\
CCWE & constituent concentrations in the waste extract \\
DDT\&E & Development, Demonstration, Testing and Evaluation \\
DOE & U.S. Department of Energy \\
DRE & destruction/removal efficiency \\
EPA & Environmental Protection Agency \\
EP Tox & Environmental Protection Toxicity Leaching Procedure \\
FFCA & Federal Facility Compliance Agreement \\
FR & Federal Register \\
HSWA & Hazardous and Solid Waste Amendments \\
ICR & ignitable, corrosive, and reactive \\
LDR & land disposal restriction \\
LLW & low-level radioactive waste \\
NRC & Nuclear Regulatory Commission \\
ORR & Oak Ridge Reservation \\
PCB & polychlorinated biphenyl \\
PCP & process control program \\
RCRA & Resource Conservation and Recovery Act \\
S/S & stabilization/solidification \\
SARA & Superfund Amendments and Reauthorization Act of 1986 \\
TOC & total organic carbon \\
TCLP & Toxicity Characteristic Leaching Procedure \\
TSCA & Toxic Substances Control Act \\
TSS & total suspended solids \\
TWA & Total Waste Analyses \\
& \\
\hline
\end{tabular}




\section{PREFACE}

The reader should note that, as a regulatory based document, this report represents a "snapshot in time" (current as of June 1,1993) and is subject to change. For example, on September 25, 1992, the United States Court of Appeals for the District of Columbia Circuit ruled on the various petitions for review filed against the Third rule. [Chemical Waste Management, Inc., et al. v. EPA, 976 F. 2d 2 (58 FR 29861)]. On May 24, 1993, as part of its response to the September 25 decision, the EPA stated "The Agency plans to address issues which have been remanded by the court in future rulemaking." (58 FR 29865). Clearly, additional rulemakings that may impact the discussions related to performance criteria in this report are forthcoming.

In addition, the reader should note that many of the leachate-concentration-based standards discussed in this report were derived from the Environmental Protection Toxicity Characteristic Leaching Procedure (EP Tox). Although the EP Tox has been replaced by the Toxicity Characteristic Leaching Procedure (TCLP), the concentrations standards have not been updated. Consequently, in many cases the threshold concentrations were originally determined by the EP Tox-not the TCLP. However, throughout this report the conservative assumption is made that the threshold values must be met by the TCLP test; and the EP Tox is neither referred to nor utilized. In so doing, the authors believe the recommended performance criteria become more conservative. 


\begin{abstract}
This document defines the product performance criteria to be used in Phase I of the Final Waste Forms Project. In Phase I, treatability studies will be performed to provide "proof-of-principle" data to establish the viability of stabilization/solidification (S/S) technologies. This information is required by March 1995. In Phase II, further treatability studies, some at the pilot scale, will be performed to provide sufficient data to allow treatment alternatives identified in Phase I to be more fully developed and evaluated, as well as to reduce performance uncertainties for those methods chosen to treat a specific waste. Three main factors influence the development and selection of an optimum waste form formulation and hence affect selection of performance criteria. These factors are regulatory, processspecific, and site-specific waste form standards or requirements. Clearly, the optimum waste form formulation will require consideration of performance criteria constraints from each of the three categories. Phase I will focus only on the regulatory criteria. These criteria may be considered the minimum criteria for an acceptable waste form. In other words, a $\mathrm{S} / \mathrm{S}$ technology is considered viable only if it meets applicable regulatory criteria. The criteria to be utilized in the Phase I treatability studies were primarily taken from Environmental Protection Agency regulations addressed in 40 CFR 260 through 265 and 268; and Nuclear Regulatory Commission regulations addressed in 10 CFR 61. Thus the majority of the identified criteria are independent of waste form matrix composition (i.e., applicable to cement, glass, organic binders etc.).
\end{abstract}




\section{INTRODUCTION}

On June 12, 1992, the Department of Energy (DOE) Oak Ridge Operations Office signed a Federal Facility Compliance Agreement (FFCA) with the U.S. Environmental Protection Agency Region IV (EPA-IV) regarding Oak Ridge Reservation (ORR) mixed wastes subject to the land disposal restriction (LDR) provisions of the Resource Conservation and Recovery Act (RCRA). The LDR FFCA establishes an aggressive schedule for conducting treatability studies and treatment methods development for those ORR mixed (radioactive and hazardous) wastes listed in Appendix B to the Agreement. These are wastes for which treatment methods and capabilities have yet to be defined. Compliance with Requirement 5 of the Agreement states that

... DOE shall submit to EPA (Environmental Protection Agency) for review and approval a plan for the treatment of the LDR prohibited wastes identified in Appendices $1 \mathrm{~B}, 2 \mathrm{~B}$, and $3 \mathrm{~B}$. This plan must identify the treatment strategy for such wastes to meet LDR treatment standards and must include a schedule, not to exceed two (2) years after the submittal of this plan (i.e., March 1995), for the evaluation and prioritization of treatment method options, treatability studies if required, and technology development. ${ }^{1}$

At an upper level, this requirement was satisfied by the "Strategic Plan." In the Strategic Plan, the wastes are divided into two categories:

1. those wastes, listed in Appendices 1A, 2A, and 3A of the Agreement, for which treatment methods and facilities exist and

2. those wastes, listed in Appendices 1B, 2B, and 3B of the Agreement (hereafter referred to as Appendix B wastes), for which no treatment methods or facilities exist.

A Development, Demonstration, Testing and Evaluation (DDT\&E) Program has been initiated to provide those efforts necessary to identify treatment methods for all the wastes that meet Appendix B criteria. The DDT\&E Program has assembled project teams to address treatment development needs in a variety of areas, including that of Final Waste Forms [i.e., stabilization/solidification (S/S) processes]. As the waste data become more definitively characterized, any wastes newly classified as Appendix B wastes will be so identified in updates to the FFCA and will be included in treatment development programs.

In the context of this report, solidification refers to treatment that renders the waste a "solid." Solidification encompasses technologies that remove liquid such as filtration, drying, calcination, etc., which result in a dry or solid residue. Coating the dry waste with a polymer or the like would be considered solidification within the context of this project. Stabilization, which may also involve solidification, refers to treatment that involves reaction(s) with the waste constituents of concern to render them nonhazardous or to a chemical form that is less hazardous. Since most processes involving stabilization also involve solidification, they are referred to as $\mathrm{S} / \mathrm{S}$ processes. The Final Waste Forms Project will give priority to the more traditional S/S processes, but it will not exclude such technologies as filtration, drying, etc. 
Waste form types being actively considered by this project include grout (e.g., cement-based technology), glass (e.g., vitrification technology), and organic binders (e.g., polymer encapsulation). It is not clear at present what the final form and composition of the yet-to-bedetermined treatment method residues will be and which waste streams will require, or are candidates for, S/S. In addition, ongoing waste characterization has not progressed to the point where potential waste candidates for direct $S / S$ can be readily identified. This process consists of reviewing existing waste records, conducting generator interviews, and performing sampling and analysis, where required, to acquire more detailed information on waste matrices and contaminants. As these data are obtained, candidate waste forms will become more apparent, and regulatory requirements for treatment of specific wastes can be clearly defined.

Because of the time constraints in meeting the March 1995 deliverable as specified in the LDR FFCA, waste form treatability studies must be performed in parallel with data acquisition activities described in the previous paragraph. To perform these treatability studies, we must establish product performance criteria for these studies. Because of the parallel nature of activities being performed in support of the DDT\&E Program, these waste form performance criteria must be generic rather than ORR-waste specific.

The purpose of this document is to define the product performance criteria to be used in Phase I of the Final Waste Forms Project. In Phase I, treatability studies will be performed to provide "proof-of-principle" data to establish the viability of S/S technologies. This information is required by March 1995. In Phase II, further treatability studies, some at the pilot scale, will be performed to provide sufficient data to allow treatment alternatives identified in Phase I to be more fully developed and evaluated, as well as to reduce performance uncertainties for those methods chosen to treat a specific waste. The focus of these Phase II efforts will be to obtain the necessary data to design the process module(s) and optimize the waste form formulation's ability to accommodate expected variations in both feed characteristics and process operations. While Phase I will concentrate primarily on laboratory- or bench-scale studies, Phase II will focus on laboratory-scale, as well as both bench-scale and pilot-scale, demonstrations. 


\section{RATIONALE FOR SELECTION OF PERFORMAN TE CRITERIA}

Three main factors influence the development and selection of an optimum waste form formulation and hence affect selection of performance criteria. These are regulatory, processspecific, and site-specific waste form standards or requirements. Regulatory requirements are those product performance criteria required by law or regulation and are typically site-, and may be process-, independent. For example, a waste form must meet certain concentrationbased or technology-based treatment standards, or combinations thereof, in order to be land disposed. In general, these scandards are independent of the process and waste form matrix ingredients employed (nots that where the treatment standard requires use of a specified technology, the process would not be independent).

Process-specific requirements are those pertaining to process variables/constraints such as acceptable waste form fluid viscosity, ability to control the addition and blending/mixing of the formulation ingrerients, temperature control, etc. For a grout formulation the process may place constraints on such properties as viscosity, set time, and gel strength.

Site-specific requirements are those pertaining to the storage, handling, and disposal of the waste form product. For example, the waste form may be placed in 55-gal drums, stacked four high, which may place compressive strength requirements on the product to support the intended load; or the product may be accumulated for a period of time awaiting shipment offsite and may thus require resistance to atmospheric temperature variations (freeze/thaw resistance). Note that, in addition to regulatory-driven performance criteria for the chemical components of a final waste form, allowable waste form radiological contaminant concentrations and/or activity would be a site-specific performance requirement, as defined by the performance assessment process for the individual disposal site.

Clearly, the optimum waste form formulation will require consideration of performance criteria constraints from each of the three categories. Phase I will focus only on the regulatory criteria. These criteria may be considered the minimum criteria for an acceptable waste form. In other words, a viable $S / S$ technology must meet applicable regulatory criteria. Formulation optimization would be performed only on those selected technologies whose viability has been established through screening tests. Treatability studies conducted in Phase I aim to identify viable technologies. As stated previously, formulation optimization efforts are part of the Phase II treatability studies. 


\section{RESOURCE CONVERSATION AND RECOVERY ACT AND SUBSEQUENT REAUTHORIZATION AND AMENDMENTS}

In 1976, Congress passed RCRA, which pertains to the definition, generation, transportation, treatment, storage, and disposal of hazardous wastes. The implementing regulations are found in Title 40 of the Code of Federal Regulations (CFR), Parts 260 through 265. In 1984, Congress passed the Hazardous and Solid Waste Amendments (HSWA) to RCRA, which placed stringent new restrictions on the land disposal of hazardous wastes. These restrictions, implemented in 40 CFR Part 268, require the hazardous wastes to meet concentration-based or technology-based treatment standards prior to land disposal. These restrictions, referred to as LDRs, have significantly expanded the scope and coverage of RCRA. As such, they have become a major regulatory driver in determining performance criteria for treatment (e.g., S/S) of hazardous wastes.

It is beyond the scope of this report to provide a detailed analysis of RCRA, HSWA, and LDRs. However, some discussion is appropriate to provide the rationale for selection of performance criteria applicable to the Final Waste Forms Project. Five "waste groups" under LDR are potentially applicable to the LDR FFCA Appendix B wastes under this project: (1) spent solvents and dioxins, (2) wastes that were banned from land disposal by the state of California (the "California List"), (3) wastes listed in 40 CFR Part 261, (4) characteristic wastes, and (5) hazardous debris. It is assumed that LDR regulations pertaining to underground injection (40 CFR Part 148) are not applicable to this project.

These waste categories and their potential impact on this project are discussed in subsequent sections of this report. However, as stated previously, it is beyond the scope of this report to provide a detailed discussion and review of all issues/data pertaining to LDR. Only selected information is presented. To understand the basis for this selection, it is important to understand the basis for LDR treatment standards. Treatment standards include (1) specified treatment technologies, (2) specified constituent concentrations in the waste extract (CCWE), as determined by the Toxicity Characteristic Leaching Procedure (TCLP) (TCLP SW846, Method 1311) and/or (3) specified total constituent concentrations in the waste (CCW). In the case where concentration-based treatment standards must be met, any treatment technology may be used; however, concentrations of hazardous constituents remaining in the treatment residuals cannot be higher than those present when best demonstrated available technology (BDAT) is employed. If a treatment technology is specified, that technology must be used.

These treatment standards provide a potential source of performance criteria for this project. However, within each waste category, treatment standards are generally specified for nonwastewaters and wastewaters. Wastewaters are aqueous wastes containing $<1 \mathrm{wt} \%$ total organic carbon (TOC) and $<1 \mathrm{wt} \%$ total suspended solids (TSS), with the following exceptions:

1. F001, F002, F003, F004, and F005 wastewaters: solvent-water mixtures containing $<1$ wt \% TOC or $<1$ wt \% total F001, F002, F003, F004, F005 solvent constituents listed in 40 CFR 268.41, Table CCWE; 
2. K011, K013, and K014 wastewaters: containing $<5$ wt $\%$ TOC and $<1$ wt $\%$ TSS, as generated; and

3. K103 and K104 wastewaters: containing $<4 \mathrm{wt} \%$ TOC and $<1 \mathrm{wt} \%$ TSS.

Any waste or treatment residue not meeting this definition is a nonwastewater. For f siposes of the Final Waste Forms Project, only nonwastewaters are assumed to be subject to $\mathrm{S} / \mathrm{S}$. Consequently, treatment standards presented in this report are limited to those specified for nonwastewaters.

\subsection{SPENT SOLVENTS AND DIOXIN WASTES}

Spent solvents are wastes listed in 40 CFR 261.31 with waste codes F001, F002, F003, F004, and F005. Constituents of concern and associated treatment standards are shown in Table 1 . The majority of treatment standards are concentration based and primarily specify total CCW, as opposed to CCWE. Two notable exceptions are F005 spent solvent containing 2-ethoxyethanol or 2-nitropropane, for which a treatment standard of incineration is specified. Theoretically, with the exception of treatment for these two constituents in F005 wastes, or waste mixtures containing these constituents, any treatment technology (inciurding $S / S$ ) can be used as a treatment method for these waste categories as long as the concentratior-based standards are met. However, as shown in column 5 of Table 1, the specified concentrations were derived from using incineration as BDAT. Although incineration is not required for these wastes (with the two noted exceptions), the treatment utilized must be similar in performance to that of incineration in that the concentration of hazardous constituents in treatment residuals cannot be higher than those obtained using BDAT.

Dioxin wastes listed in 40 CFR 261.31 with Hazardous Waste Numbers F020-023 and F026-F028 have restrictions similar to those for spent solvents and are presented in Table 2. All treatment standards are concentration based and were derived from incineration data.

It should be noted that solids contaminated with these wastes, such as solventcontaminated soil, are subject to the LDRs, as well. Theoretically, S/S processes could be used to treat these waste types, with the exception of constituents in F005, where incineration is the specified treatment technology. However, because the treatment standards are based on incineration as the BDAT technology, it is questionable whether simple S/S will result in a waste form meeting these concentration-based treatment standards. Nevertheless, if $S / S$ processes are applied to these wastes, the product performance criteria will be the concentration-based standards listed in Tables 1 and 2, with the exceptions discussed in Sect. 3.3.2.

\subsection{CALIFORNIA LIST WASTES}

Wastes referred to as the California List became regulated on July 8, 1987. These wastes consisted of specific liquids and nonliquids containing halogenated organic compounds, hazardous waste liquids containing specific levels of polychlorinated biphenyls (PCBs), acid wastes with a $\mathrm{pH}$ less than or equal to 2.0 , and liquids containing free cyanides or certain metals. The California List has essentially become obsolete, since the new LDR treatment 
Table 1. Treatment standards for spent solvent wastes (nonwastewater)

\begin{tabular}{|c|c|c|c|c|}
\hline \multirow[b]{2}{*}{ Hazardous waste description } & \multirow[b]{2}{*}{ Constituents of concern } & \multicolumn{2}{|c|}{ Treatment standards } & \multirow{2}{*}{$\begin{array}{l}\text { BDAT used to } \\
\text { derive treatment } \\
\text { standards }\end{array}$} \\
\hline & & $\begin{array}{l}\text { Total composition } \\
\text { (mg/kg) }\end{array}$ & $\begin{array}{l}\text { TCLP } \\
(\mathrm{mg} / \mathrm{L})\end{array}$ & \\
\hline $\begin{array}{l}\text { FO01-Spent halogenated solvents used } \\
\text { in degreasing }\end{array}$ & $\begin{array}{l}\text { Carbon tetrachloride } \\
\text { Methylene chloride } \\
\text { Tetrachloroethylene } \\
\text { 1,1,1-Trichoroethane } \\
\text { Trichloroethylene } \\
\text { 1,1,2-Trichloro-1,2,2-trifluoroethane } \\
\text { Trichloromonofluoromethane }\end{array}$ & $\begin{array}{c}5.6 \\
33 \\
5.6 \\
5.6 \\
5.6 \\
28 \\
33\end{array}$ & & $\begin{array}{l}\text { Incineration } \\
\text { Incineration } \\
\text { Incineration } \\
\text { Incineration } \\
\text { Incineration } \\
\text { Incineration } \\
\text { Incineration }\end{array}$ \\
\hline FO02-Spent halogenated solvents & $\begin{array}{l}\text { Chlorobenzene } \\
\text { o-Dichlorobenzene } \\
\text { Methylene chloride } \\
\text { Tetrachloroethylene } \\
\text { 1,1,1-Trichloroethane } \\
\text { 1,1,2-Trichloroethane } \\
\text { Trichloroethylene } \\
\text { 1,1,2-Trichloro-1,2,2-trifluoroethane } \\
\text { Trichloromonofluoromethane }\end{array}$ & $\begin{array}{c}5.7 \\
6.2 \\
33 \\
5.6 \\
5.6 \\
7.6 \\
5.6 \\
28 \\
33\end{array}$ & & $\begin{array}{l}\text { Incineration } \\
\text { Incineration } \\
\text { Incineration } \\
\text { Incineration } \\
\text { Incineration } \\
\text { Incineration } \\
\text { Incineration } \\
\text { Incineration } \\
\text { Incineration }\end{array}$ \\
\hline F003-Spent nonhalogenated solvents & $\begin{array}{l}\text { Acetone } \\
\text { n-Butyl alcohol } \\
\text { Cyclohexanone } \\
\text { Ethyl acetate } \\
\text { Ethyl benzene } \\
\text { Ethyl ether } \\
\text { Methanol } \\
\text { Methyl isobutyl ketone } \\
\text { Xylenes (total) }\end{array}$ & $\begin{array}{c}160 \\
2.6 \\
33 \\
6.0 \\
160 \\
33 \\
28\end{array}$ & 0.75 & $\begin{array}{l}\text { Incineration } \\
\text { Incineration } \\
\text { Incineration } \\
\text { Incineration } \\
\text { Incineration } \\
\text { Incineration } \\
\text { Incineration } \\
\text { Incineration } \\
\text { Incineration }\end{array}$ \\
\hline
\end{tabular}


Table 1 (continued)

\begin{tabular}{|c|c|c|c|c|}
\hline \multirow[b]{2}{*}{ Hazardous waste description } & \multirow[b]{2}{*}{ Constituents of concern } & \multicolumn{2}{|c|}{ Treatment standards } & \multirow{2}{*}{$\begin{array}{l}\text { BDAT used to } \\
\text { derive treatment } \\
\text { standards }\end{array}$} \\
\hline & & $\begin{array}{c}\text { Total composition } \\
(\mathrm{mg} / \mathrm{kg})\end{array}$ & $\begin{array}{l}\text { TCLP } \\
(\mathrm{mg} / \mathrm{L})\end{array}$ & \\
\hline F004-Spent nonhalogenated solvents & $\begin{array}{l}\text { Cresol (m- and } p \text { - isomers) } \\
\text { o-Cresol } \\
\text { Nitrobenzene }\end{array}$ & $\begin{array}{l}3.2 \\
5.6 \\
14\end{array}$ & & $\begin{array}{l}\text { Incineration } \\
\text { Incineration } \\
\text { Incineration }\end{array}$ \\
\hline F005-Spent nonhalogenated solvents & $\begin{array}{l}\text { Benzene } \\
\text { Carbon disulfide } \\
\text { 2-Ethoxyethanol } \\
\text { Isobutyl alcohol } \\
\text { Methyl ethyl ketone } \\
\text { 2-Nitropropane } \\
\text { Pyridine } \\
\text { Toluene }\end{array}$ & $\begin{array}{c}3.7 \\
\text { Incineration } \\
170 \\
36 \\
\text { Incineration } \\
16 \\
28\end{array}$ & 4.8 & $\begin{array}{l}\text { Incineration } \\
\text { Incineration } \\
\text { Specified } \\
\text { Incineration } \\
\text { Incineration } \\
\text { Specified } \\
\text { Incineration } \\
\text { Incineration }\end{array}$ \\
\hline
\end{tabular}


Table 2. Treatment standards for dioxin wastes (nonwastewater)

\begin{tabular}{|c|c|c|c|c|}
\hline Hazardous wasie description & Constituents of concern & $\begin{array}{c}\text { Total composition } \\
(\mathrm{mg} / \mathrm{kg})\end{array}$ & $\begin{array}{l}\text { TCLP } \\
(\mathrm{mg} / \mathrm{L})\end{array}$ & $\begin{array}{l}\text { BDAT used to } \\
\text { derive treatment } \\
\text { standards }\end{array}$ \\
\hline $\mathrm{FO} 20-\mathrm{FO} 23$ & $\begin{array}{l}\text { HxCDD-All Hexachlorodibenzo-p-dioxins } \\
\text { HxCDF-All Hexachlorodibenzo-furans } \\
\text { PeCDD-All Pentachlorodibenzo-p-dioxins } \\
\text { PeCDF-All Pentachlorodibenzo-furans } \\
\text { TCDD-All Tetrachlorodibenzo-p-dioxins } \\
\text { TCDF-All Tetrachlorodibenzo-furans } \\
\text { 2,4,5-Trichlorophenol } \\
\text { 2,4,6-Trichlorophenol } \\
\text { 2,3,4,6-Tetrachlorophenol } \\
\text { Pentachlorophenol }\end{array}$ & & $\begin{array}{l}<1 \mathrm{ppb} \\
<1 \mathrm{ppb} \\
<1 \mathrm{ppb} \\
<1 \mathrm{ppb} \\
<1 \mathrm{ppb} \\
<1 \mathrm{ppb} \\
<0.05 \mathrm{ppm} \\
<0.05 \mathrm{ppm} \\
<0.05 \mathrm{ppm} \\
<0.01 \mathrm{ppm}\end{array}$ & $\begin{array}{l}\text { Incineration } \\
\text { Incineration } \\
\text { Incineration } \\
\text { Incineration } \\
\text { Incineration } \\
\text { Incineration } \\
\text { Incineration } \\
\text { Incineration } \\
\text { Incineration } \\
\text { Incineration }\end{array}$ \\
\hline F026-F028 & $\begin{array}{l}\text { HxCDD-All Hexachlorodibenzo-p-dioxins } \\
\text { HxCDF-All Hexachlorodibenzo-furans } \\
\text { PeCDD-All Pentachlorodibenzo-p-dioxins } \\
\text { PeCDF-All Pentachlorodibenzo-furans } \\
\text { TCDD-All Tetra-chlorodibenzo-p-dioxins } \\
\text { TCDF-All Tetra-chlorodibenzo-furans } \\
\text { 2,4,5-Trichlorophenol } \\
\text { 2,4,6-Trichlorophenol } \\
\text { 2,3,4,6-Tetrachlorophenol } \\
\text { Pentachlorophenol }\end{array}$ & & $\begin{array}{l}<1 \mathrm{ppb} \\
<1 \mathrm{ppb} \\
<1 \mathrm{ppb} \\
<1 \mathrm{ppb} \\
<1 \mathrm{ppb} \\
<1 \mathrm{ppb} \\
<0.05 \mathrm{ppm} \\
<0.05 \mathrm{ppm} \\
<0.05 \mathrm{ppm} \\
<0.01 \mathrm{ppm}\end{array}$ & $\begin{array}{l}\text { Incineration } \\
\text { Incineration } \\
\text { Incineration } \\
\text { Incineration } \\
\text { Incineration } \\
\text { Incineration } \\
\text { Incineration } \\
\text { Incineration } \\
\text { Incineration } \\
\text { Incineration }\end{array}$ \\
\hline
\end{tabular}


standards EPA has promulgated since 1987 take precedent over the original California list treatment standards. However, three exceptions exist for which the original California List treatment standards are still applicable. One is for liquid characteristic hazardous wastes containing $\geq 50 \mathrm{ppm}$ PCBs. The second is for certain characteristically hazardous wastes (solids and liquids) that contain $\geq 1000 \mathrm{ppm}$ halog nated organic compounds, as specifically defined in 40 CFR Part 268, Appendix III. These two special cases will be discussed in Sect. 4.

The third exception is characteristically hazardous liquid waste containing $\geq 134 \mathrm{mg} / \mathrm{L}$ nickel and/or $130 \mathrm{mg} / \mathrm{L}$ thallium. Neither nickel nor thallium is designated as a characteristically hazardous constituent (see Sect. 3.4) and therefore is not subject to more specific treatment standards applicable to characteristically hazardous wastes. Any treatment technology can be used to treat the waste to reduce nickel and/or thallium concentrations to below the specified threshold concentrations, or the waste can be rendered a solid through an $\mathrm{S} / \mathrm{S}$ process.

Note that a solid is defined by the EPA to be a material that passes the Paint Filter Liquid Test (SW846, Method 9095). This definition will be used as a Final Waste Form performance criterion. That is, all waste form products must be classified as a solid according to this test.

\subsection{LISTED WASTES}

Listed wastes are wastes that are specifically classified as hazardous because of their source or for other properties, such as ignitability, corrosivity, reactivity, or toxicity. These wastes, listed in 40 CFR 261.31-261.33, are sometimes referred to as the first-, second-, and third-thirds because of the way in which their LDR treatment standards were promulgated. The "derived-from" rule [40 CFR 261.3(c)(2)] requires that residues from the treatment of RCRA listed waste must themselves be considered listed wastes until delisted. These treatment residues may have to meet the same treatment standards as the original waste, depending on the treatability group to which they belong and whether or not the residues qualify as a wastewater or nonwastewater. Consequently, whenever a concentration-based treatment standard exists for a listed waste, then residues generated from the treatment of that waste will be subject to the applicable constituent standards for wastewaters or nonwastewaters, as appropriate.

\subsubsection{Treatment Standards}

As described previously, treatment standards can be either concentration based or technology based. Treatment standards for listed wastes are presented in Appendix A. Detailed descriptions of technology codes used in Appendix A are provided in Appendix B. As noted in Appendix A, stabilization is BDAT for only a few select wastes. However, if stabilization is used as a treatment method, then the specified concentration limits become final waste form product performance criteria (with the exception noted in Sect. 3.3.2.).

\subsubsection{Electroplating wastes (F006-F009)}

Wastes from electroplating operations typically are associated with a high iron content that can form stable iron/cyanide complexes. Because these complexes degrade with time to 
evolve free cyanide, the treatment standard is based on total cyanide concentration in the waste rather than leachable cyanide based on TCLP. EPA has specifically stated that stabilization of cyanides is impermissible dilution. Therefore, the assumption is made that $S / S$ (in the absence of cyanide destruction) is not a viable treatment for cyanides regardless of waste code and that any such waste will be pretreated for cyanide removal by the specified BDAT, or equivalent, prior to $\mathrm{S} / \mathrm{S}$.

\subsubsection{Stabilization as specified BDAT}

As shown in Appendix A, the majority of listed wastes have concentration-based treatment standards. However, a few have specified treatment technologies as the required treatment standard, and fewer still have stabilization as the specified BDAT. Stabilization, as defined by the EPA, ${ }^{3}$ means "stabilization with the following reagents (or waste reagents) or combinations of reagents: (1) Portland cement; or (2) lime/pozzolans (e.g., fly ash and cement kiln dust). . . this does not preclude the addition of reagents (e.g., iron salts, silicates, and clays) designed to enhance the set/cure time and/or compressive strength, or to overall reduce the leachability of the metal or inorganic." In the context of the Final Waste Forms Project, this definition corresponds to grout. Thus, grout is the reagent of choice for stabilization of the following wastes: P113, P115, P119, P120, U214, U215, U216, and U217, and stabilization in grout is a performance criterion for these waste categories.

\subsubsection{Amalgamation as specified BDAT}

As defined by the EPA ${ }^{3}$, amalgamation means "amalgamation of liquid, elemental mercury contaminated with radioactive materials utilizing inorganic reagents such as copper, zinc, nickel, gold, and sulfur that result in a nonliquid, semi-solid amalgam and thereby reducing potential emissions of elemental mercury vapors to the air." Amalgamation is the specified treatment technology for the U151 waste subcategory, "mercury contaminated with radioactive materials." Because the treatment standard is a specified technology, amalgamation would have to occur prior to any further $S / S$ of the waste containing the mercury. However, two $S / S$ techniques are under investigation that potentially incorporate amalgamation as part of the $\mathrm{S} / \mathrm{S}$ process (i.e., without separate amalgamation pretreatment). If results of further tests are promising, a regulatory determination will be made as to whether an "Equivalent Technology" demonstration (40 CFR 268.42) should be pursued for one or both of these technologies. If successful, one of the two identified processes for the direct S/S of this waste category would then become a performance criterion. If not, separate amalgamation pretreatment will be required.

\subsubsection{Basis for specified concentration limits}

It is important to note $t$. at where concentrations are specified as the treatment standards for nonwastewaters (to which this document applies), these limits were derived from performance data from technologies EPA considers BDAT. Concentration limits specified for organic constituents were derived from technologies other than stabilization, while, in many cases, the concentration limits for inorganic constituents (including those contained in rcsicues from organic waste treatment) are based on stabilization. Collectively, this information provides guidance to this project in two important areas: (1) identification of wastes that are amenable (in a regulatory context) to stabilization and (2) definition of expected performance, as defined by TCLP leachate concentrations for nonwastewaters, from the stabilized product. 
Table 3 summarizes the waste codes (from Appendix A) fo: which stabilization was used to determine required TCLP concentration treatment standards. Because these are nonwastewaters, no total waste concentration treatment standards are associated with these wastes. For the Final Waste Forms Project, Table 3 lists wastes amenable to stabilization, and the TCLP limits become product performance criteria. Note also that many species have different TCLP concentration limits, depending on the applicable waste code. (Although Energy Systems does not generate " $K$ " wastes on the ORR, these codes were included for completeness of this table and those that follow.)

Table 3. Treatment standards for listed wastes (nonwastewater) based on stabilization as BDAT

\begin{tabular}{|c|c|c|c|c|c|c|}
\hline \multirow{2}{*}{ Waste code ${ }^{a}$} & \multicolumn{6}{|c|}{ TCLP concentration standard (mg/L) } \\
\hline & $\mathrm{Cd}$ & $\mathrm{Pb}$ & Se & $\mathrm{Ag}$ & $\mathrm{Cr}$ & $\mathbf{N i}$ \\
\hline K061 & 0.19 & 0.37 & 0.16 & 0.3 & 0.33 & 5 \\
\hline K069-Calcium sulfate category & 0.14 & 0.37 & & & & \\
\hline K100 & 0.066 & 0.51 & & & 5.2 & \\
\hline K115 & & & & & & 0.32 \\
\hline P073 & & & & & & 0.32 \\
\hline P103 & & & 5.7 & & & \\
\hline P114 & & & 5.7 & & & \\
\hline U204 & & & 5.7 & & & \\
\hline U205 & & & 5.7 & & & \\
\hline
\end{tabular}

"Although Energy Systems does not generate "K" wastes on the ORR, these standards are included for completeness of the table.

Although vitrification was the treatment technology used (i.e., BDAT) in establishing the constituent concentration in the waste extract standard of $5.6 \mathrm{mg} / \mathrm{L}$ for numerous nonwastewater waste categories containing arsenic, any stabilization method may be used as long as the concentration-based standards are met. These wastes include: K031, K084, K101, K102, P010, P011, P012, P036, P038, and U136. In the context of the Final Waste Forms Projec $^{+}$, these wastes are amenable to $\mathrm{S} / \mathrm{S}$, and a TCLP concentration of $5.6 \mathrm{mg} / \mathrm{L}$ for arsenic becomes a waste form product performance criterion for these waste categories. Note also (Appendix A) that none of these nonwastewater waste categories have a specified maximum total CCW with respect to arsenic.

Table 4 highlights the concentration-based treatment standards for selected nonwastewater treatment residues. As stated previously, in all cases the BDAT tr zatment of organic species in listed wastes is by some method(s) other than stabilization. However, the concentration limits in Table 4 were derived from use of stabilization processes as the BDAT for the treatment of the inorganic species remaining in the residue generated following 
Table 4. TCLP treatment standards based on stabilization as BDAT for treatment residues of listed wastes (nonwastewater)

\begin{tabular}{|c|c|c|c|c|c|c|c|c|c|c|}
\hline \multirow{2}{*}{ Waste code ${ }^{a}$} & \multicolumn{10}{|c|}{ TCLP concentration standard (mg/L) } \\
\hline & $\mathrm{Cd}$ & $\mathrm{Cr}$ & $\mathbf{P b}$ & $\mathbf{N i}$ & $\mathrm{Ag}$ & Sb & As & $\mathrm{Ba}$ & $\mathrm{Hg}$ & $\mathrm{Se}$ \\
\hline F006 & 0.066 & 5.2 & 0.51 & 0.32 & 0.072 & & & & & \\
\hline F007 & 0.066 & 5.2 & 0.51 & 0.32 & 0.072 & & & & & \\
\hline F008 & 0.066 & 5.2 & 0.51 & 0.32 & 0.072 & & & & & \\
\hline F009 & 0.066 & 5.2 & 0.51 & 0.32 & 0.072 & & & & & \\
\hline F011 & 0.066 & 5.2 & 0.51 & 0.32 & 0.072 & & & & & \\
\hline F012 & 0.066 & 5.2 & 0.51 & 0.32 & 0.072 & & & & & \\
\hline F019 & & 5.2 & & & & & & & & \\
\hline FO24 & & 0.073 & - & 0.088 & & & & & & \\
\hline F039 & 0.066 & 5.2 & 0.51 & 0.32 & 0.072 & 0.23 & 5.0 & 52 & 0.025 & 5.7 \\
\hline K001 & & & 0.51 & & & & & & & \\
\hline K006 & & 0.094 & 0.37 & & & & & & & \\
\hline K015 & & 1.7 & & 0.2 & & & & & & \\
\hline K021 & & & & & & 0.23 & & & & \\
\hline K022 & & 5.2 & & 0.32 & & & & & & \\
\hline $\mathrm{K} 024^{b}$ & & & & & & & & & & \\
\hline K028 & . & 0.073 & 0.021 & 0.088 & & & & & & \\
\hline K046 & & & 0.18 & & & & & & & \\
\hline K048 & & 1.7 & & 0.2 & & & & & & \\
\hline K049 & & 1.7 & & 0.2 & & & & & & \\
\hline
\end{tabular}


Table 4 (continued)

\begin{tabular}{|c|c|c|c|c|c|c|c|c|c|c|}
\hline \multirow{2}{*}{ Waste code ${ }^{a}$} & \multicolumn{10}{|c|}{ TCLP concentration standard $(\mathrm{mg} / \mathrm{L})$} \\
\hline & $\mathbf{C d}$ & $\mathbf{C r}$ & $\mathbf{P b}$ & $\mathbf{N i}$ & $\mathbf{A g}$ & $\mathbf{S b}$ & As & $\mathbf{B a}$ & $\mathrm{Hg}$ & $\mathrm{Se}$ \\
\hline K050 & & 1.7 & & 0.2 & & & & & & \\
\hline K051 & & 1.7 & & 0.2 & & & & & & \\
\hline K052 & & 1.7 & & 0.2 & & & & & & \\
\hline K083 & & & & 0.088 & & & & & & \\
\hline K087 & & & 0.51 & & & & & & & \\
\hline P013 & & & & 0.32 & & & & 52 & & \\
\hline P074 & & & & & & & & & & \\
\hline P099 & & & & & 0.072 & & & & & \\
\hline U051 & & & 0.51 & & & & & & & \\
\hline U144 & & & 0.51 & & & & & & & \\
\hline U145 & & & 0.51 & & & & & & & \\
\hline U146 & & & 0.51 & & & & & & & \\
\hline
\end{tabular}

${ }^{a}$ Energy Systems does not generate " $K$ " wastes: they are included for completeness of the table.

${ }^{b}$ Stabilization of ash residue. 
pretreatments for organic destruction/removal from these waste categories. In the context of the Final Waste Forms Project, inorganic residues remaining after treatment for destruction/removal of organics for these waste categories (or codes) are amenable to $S / S$, and the waste form product performance criteria are the TCLP limits listed in Table 4.

\subsubsection{Organics}

As shown in Appendix A, a significant portion of listed wastes has total waste composition treatment standards specified for organic constituents. Although these standards are requirements for land disposal of a waste form containing these constituents, they are NOT waste form product performance criteria for grout and organic binder products in the Phase I treatability studies to be performed under the Final Waste Forms Project. Per 40 CFR 268.3(a), the EPA specifically prohibits dilution of a listed waste or its treatment residues in order to meet treatment standards. Both grout and organic binders would be considered dilution if used to meet the total concentration limits for organics. Consequently, listed wastes that have organic constituents at concentration levels above the treatment standards are not amenable to direct $S / S$ and therefore require pretreatment.

However, these total concentration limits can be used to define the maximum concentration of organic constituents allowed in the waste fed to $S / S$ operations and hence the Phase I treatability studies. For purposes of designing Final Waste Form treatability studies, it will be assumed (subject to verification by sampling and analysis) that the waste feed to be addressed by S/S studies has been, or will be, pretreated to meet the applicable total concentration treatment standards for organics prior to being introduced to the $S / S$ process.

It should be noted that there is one possible exception to this discussion. Vitrification, a waste form technology within this project, is considered a "thermal treatment" technology by the EPA (57 FR 37240). Consequently, vitrification may be an option for direct stabilization of listed wastes in these categories. If the treatability studies evaluate this option, then the applicable organic constituents' total concentration standards become performance criteria for the study. However, in this case the performance criteria are related to organic destruction/removal efficiency (DRE) in the melting process rather than to the product waste form and would therefore not be considered dilution.

\subsection{CHARACTERISTIC WASTES}

Treatment standards for characteristically hazardous wastes are shown in Table 5. They are similar in nature to those discussed for listed wastes. Characteristic wastes are those which exhibit the characteristic of ignitability, corrosivity, reactivity, or toxicity, as defined in 40 CFR 261.21-261.24.

Macroencapsulation with a surface coat or jacket is a performance criterion for the subcategory of D008, "Radioactive lead solids" (see Table 5). Macroencapsulation, as defined by the EPA, ${ }^{3}$ means "macroencapsulation with surface coating materials such as polymeric organics (e.g., resins and plastics) or with a jacket of inert inorganic materials to substantially reduce the surface exposure to potential leaching media. This definition corresponds to organic binders in the context of the Final Waste Forms Project. Macroencapsulation specifically does not include any material that would be classified as a tank or container according to 40 CFR 260.10." 
Table 5. Treatment standards for characteristic wastes (nonwastewater)

\begin{tabular}{|c|c|c|c|c|}
\hline Hazardous waste description ${ }^{a}$ & $\begin{array}{l}\text { Constituents } \\
\text { of concern }\end{array}$ & $\begin{array}{c}\text { Total composition } \\
(\mathbf{m g} / \mathbf{k g})\end{array}$ & $\begin{array}{l}\text { TCLP } \\
(\mathrm{mg} / \mathrm{L})\end{array}$ & $\begin{array}{l}\text { BDAT used to derive } \\
\text { treatment standards }\end{array}$ \\
\hline $\begin{array}{l}\text { DO01-Ignitable liquids-High TOC } \\
\text { (TOC } \geq 10 \% \text { ) }\end{array}$ & & $\begin{array}{l}\text { Fuel substitution, recovery } \\
\text { of organics, or incineration }\end{array}$ & & \\
\hline $\begin{array}{l}\text { D001-Ignitables (except high TOC) } \\
\text { managed in CWA, }{ }^{b} \mathrm{CWA} \text {-equivalent, or } \\
\text { Class I SDWA }{ }^{c} \text { systems }\end{array}$ & & Deactivation & & $\begin{array}{l}\text { Recovery of organics, } \\
\text { incineration, wet-air oxidation, } \\
\text { chemical/ } \\
\text { electrolytic oxidation, } \\
\text { biodegradation }\end{array}$ \\
\hline $\begin{array}{l}\text { D001-Ignitables (except high TOC) } \\
\text { managed in non-CWA/non-CWA- } \\
\text { equivalent/non-Class I SDWA systems }\end{array}$ & & $\begin{array}{l}\text { Deactivation and meet } \\
\text { F039; fuel substitution; } \\
\text { recovery of organics; or } \\
\text { Incineration }\end{array}$ & & $\begin{array}{l}\text { Recovery of organics, } \\
\text { incineration, wet-air oxidation, } \\
\text { chemical/ } \\
\text { electrolytic oxidation, } \\
\text { biodigradation }\end{array}$ \\
\hline $\begin{array}{l}\text { D0O2-Acids, alkalines, and other } \\
\text { corrosives managed in non-CWA/non- } \\
\text { CWA-equivalent/non-Class I SDWA } \\
\text { systems }\end{array}$ & & Deactivation and meet F039 & & $\begin{array}{l}\text { Recovery, neutralization, } \\
\text { incineration }\end{array}$ \\
\hline $\begin{array}{l}\text { DO02-Acids, alkalines, and other } \\
\text { corrosives managed in CWA, CWA- } \\
\text { equivalent, or Class I SDWA systems }\end{array}$ & & Deactivation & & Neutralization, incineration \\
\hline DO03-Reactive cyanides subcategory & $\begin{array}{l}\text { Cyanides } \\
\text { (total) } \\
\text { Cyanides } \\
\text { (amenable) }\end{array}$ & 590 & & $\begin{array}{l}\text { Alkaline chlorination, wet air } \\
\text { oxidation, or electrolytic } \\
\text { oxidation }\end{array}$ \\
\hline D003-Reactive sulfides subcategory & & Deactivation & & \\
\hline D003-Explosives subcategory & & Deactivation & & $\begin{array}{l}\text { Incineration, chemical/electrolytic } \\
\text { oxidation, chemical reduction }\end{array}$ \\
\hline D003 - Water reactives subcategory & & Deactivation & & $\begin{array}{l}\text { Incineration, controlled reaction } \\
\text { with water, chemical/electrolytic } \\
\text { oxidation, chemical reduction }\end{array}$ \\
\hline
\end{tabular}


Table 5 (continued)

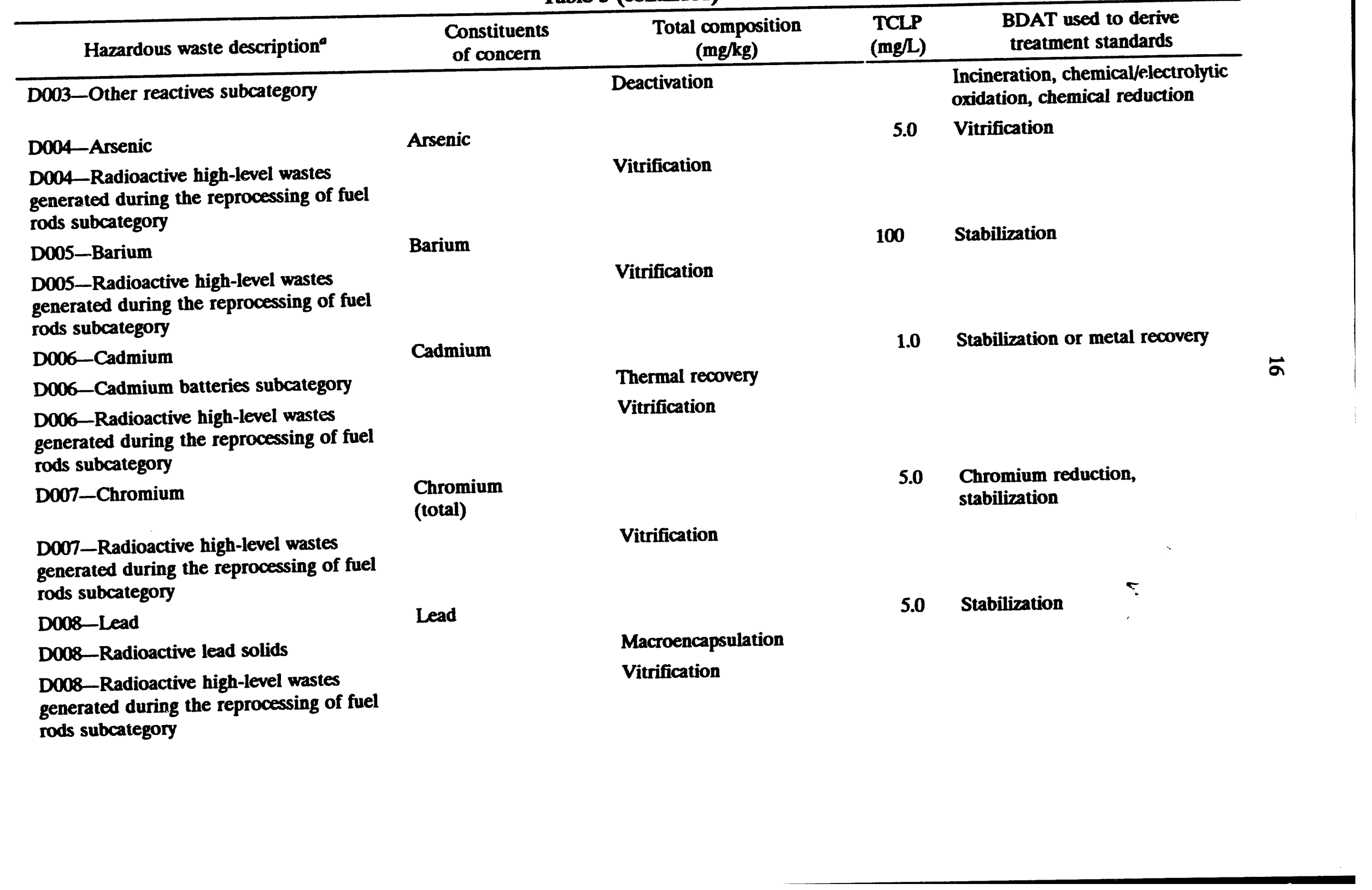


Table 5 (continued)

\begin{tabular}{|c|c|c|c|c|c|}
\hline Hazardous waste description ${ }^{a}$ & $\begin{array}{l}\text { Constituents } \\
\text { of concern }\end{array}$ & $\begin{array}{c}\text { Total composition } \\
(\mathrm{mg} / \mathrm{kg})\end{array}$ & $\begin{array}{l}\text { TCLP } \\
(\mathrm{mg} / \mathrm{L})\end{array}$ & $\begin{array}{l}\text { BDAT used to derive } \\
\text { treatment standards }\end{array}$ & \\
\hline D008-Lead acid batteries & & $\begin{array}{l}\text { Thermal recovery of lead in } \\
\text { secondary lead smelters }\end{array}$ & & & \\
\hline $\begin{array}{l}\text { D009-Low-mercury subcategory } \\
\text { (<260 mg/kg total mercury) }\end{array}$ & Mercury & & 0.20 & $\begin{array}{l}\text { Acid leaching followed by } \\
\text { chemical precipitation, } \\
\text { dewatering }\end{array}$ & \\
\hline $\begin{array}{l}\text { D009_High-mercury subcategory } \\
\text { ( } 2260 \mathrm{mg} / \mathrm{kg} \text { total mercury) }\end{array}$ & & $\begin{array}{l}\text { Roasting or retorting or } \\
\text { incineration followed by } \\
\text { roasting or retorting of } \\
\text { incinerator nonwastewater } \\
\text { residues }\end{array}$ & 0.20 & (Treatment method specified) & \\
\hline $\begin{array}{l}\text { D009-Hydraulic oil contaminated with } \\
\text { mercury and radioactive materials } \\
\text { subcategory }\end{array}$ & & $\begin{array}{l}\text { Incineration followed by } \\
\text { treatment of residues } \\
\text { according to high- or } \\
\text { low-mercury subcategory }\end{array}$ & & & $\Xi$ \\
\hline $\begin{array}{l}\text { D009-Elemental mercury contaminated } \\
\text { with radioactive materials }\end{array}$ & & Amalgamation & & & \\
\hline $\begin{array}{l}\text { D009-Radioactive high-level wastes } \\
\text { generated during the reprocessing of fuel } \\
\text { rods subcategory }\end{array}$ & & Vitrification & & & \\
\hline D010-Selenium & Selenium & & 5.7 & Stabilizaiton & \\
\hline $\begin{array}{l}\text { D010-Radioactive high-level wastes } \\
\text { generated during the reprocessing of fuel } \\
\text { rods subcategory }\end{array}$ & & Vitrification & & & \\
\hline D011-Silver & Silver & & 5.0 & Stabilization or recovery & \\
\hline $\begin{array}{l}\text { D011-Radioactive high-level wastes } \\
\text { generated during the reprocessing of fuel } \\
\text { rods subcategory }\end{array}$ & & Vitrification & & & \\
\hline
\end{tabular}


Table 5 (continued)

\begin{tabular}{|c|c|c|c|c|}
\hline Hazardous waste description ${ }^{a}$ & $\begin{array}{c}\text { Constituents } \\
\text { of concern }\end{array}$ & $\begin{array}{c}\text { Total composition } \\
\text { (mg/kg) }\end{array}$ & $\begin{array}{l}\text { TCLP } \\
(\mathrm{mg} / \mathrm{L})\end{array}$ & $\begin{array}{l}\text { BDAT used to derive } \\
\text { treatment standards }\end{array}$ \\
\hline D012-Endrin & Endrin & 0.13 & & Incineration \\
\hline D013-Lindane & Lindane & 0.066 & & Incineration \\
\hline D014-Methoxychlor & Methoxychlor & 0.18 & & Incineration \\
\hline D015-Toxaphene & Toxaphene & 1.3 & & Incineration \\
\hline D016-2,4-D & 2,4-D & 10.0 & & Incineration \\
\hline D017-2,4,5-TP (Silvex) & 2,4,5-TP & 7.9 & & Incineration \\
\hline D018-Benzene & Benzene & 10.0 & & Incineration \\
\hline D019-Carbon tetrachloride & Carbon tetrachloride & 6.0 & & Incineration \\
\hline D020-Chlordane & Chlordane & 0.26 & & Incineration \\
\hline D021-Chlorobenzene & Chlorobenzene & 6.0 & & Incineration \\
\hline D022-Chloroform & Chloroform & 6.0 & & Incineration \\
\hline D023-o-Cresol & o-Cresol & 5.6 & & Incineration \\
\hline D024-m-Cresol & m-Crescl & 3.2 & & Incineration \\
\hline D025-p-Cresol & p-Cresol & 3.2 & & Incineration \\
\hline D026-Cresol & Cresol & 8.8 & & Incineration \\
\hline D027-1,4 Dichlorobenzene & 1,4 Dichlorobenzene & 6.0 & & Incineration \\
\hline D028-1,2 Dichloroethane & 1,2 Dichloroethane & 6.0 & & Incineration \\
\hline D029-qxl 1,1 Dichloroethylene & $\begin{array}{l}\text { qxi } 1,1 \\
\text { Dichloroethylene }\end{array}$ & 6.0 & & Incineration \\
\hline D030-2,4 Dinitrotoluene & 2,4 Dinitrotoluene & 140.0 & & Incineration \\
\hline D031-Heptachlor & Heptachlor & 0.066 & & Incineration \\
\hline D031-Heptachlor epoxide & Heptachlor epoxide & 0.066 & & Incineration \\
\hline
\end{tabular}


Table 5 (continued)

\begin{tabular}{|c|c|c|c|c|}
\hline Hazardous waste description ${ }^{a}$ & $\begin{array}{c}\text { Constituents } \\
\text { of concern } \\
\end{array}$ & $\begin{array}{c}\text { Total composition } \\
(\mathrm{mg} / \mathrm{kg})\end{array}$ & $\begin{array}{l}\text { TCLP } \\
(\mathrm{mg} / \mathrm{L})\end{array}$ & $\begin{array}{l}\text { BDAT used to derive } \\
\text { treatment standards }\end{array}$ \\
\hline D032-Hexachlorobenzene & Hexachlorobenzene & 10.0 & & Incineration \\
\hline D033-Hexachloro 1,3 butadiene & $\begin{array}{l}\text { Hexachloro } 1,3 \\
\text { butadiene }\end{array}$ & 5.6 & & Incineration \\
\hline D034-Hexachloroethane & Hexachloroethane & 30.0 & & Incineration \\
\hline D035-Methyl ethyl ketone & Methyl ethyl ketone & 36.0 & & Incineration \\
\hline D036-Nitrobenzene & Nitrobenzene & 14.0 & & Incineration \\
\hline D037-Pentachlorophenol & Pentachlorophenol & 7.4 & & Incineration \\
\hline D038-Pyridine & Pyridine & 16.0 & & Incineration \\
\hline D039-Tetrachloroethylene & Tetrachloroethylene & 6.0 & & Incineration \\
\hline D040_Trichloroethylene & Trichloroethylene & 6.0 & & Incineration \\
\hline D041-2,4,5 Trichlorophenol & 2,4,5 Trichlorophenol & 7.4 & & Incineration \\
\hline D042-2,4,6 Trichlurophenol & 2,4,6 Trichlorophenol & 7.4 & & Incineration \\
\hline D043-Vinyl chloride & Vinyl Chloride & 6.0 & & Incineration \\
\hline
\end{tabular}

a Waste Codes D018 through D043 for TCLP Program have proposed treatment standards and are subject to final approval and promulgation (58 FR 48092-48204).

${ }^{b}$ Regulated under Clean Water Act (CWA).

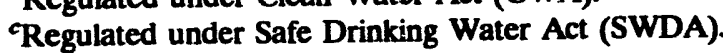


For the subcategory of D009, "Elemental mercury contaminated with radioactive materials," amalgamation is specified as the required treatment technology. As previously discussed, any other S/S required would have to occur following amalgamation. However, two stabilization techniques are under investigation which potentially incorporate amalgamation as part of the $\mathrm{S} / \mathrm{S}$ process (i.e., without separate amalgamation pretreatment). If results of further tests are promising, a regulatory determination will be made as to whether an "Equivalent Technology" demonstration (40 CFR 268.42) should be pursued for one or both of these technologies. If successful, the performance criterion would then become the use of one of the two identified processes. If not, separate amalgamation pretreatment will be required. It should be noted that the treatment standards for the majority of the remaining D009 subcategories involve either a chemical or thermal treatment. Consequently, these waste categories are not amenable to direct $\mathrm{S} / \mathrm{S}$ with the possible exception of vitrification technology. Although vitrification is a waste form technology within this project, it is considered by the EPA to be a thermal treatment technology.

Table 6 summarizes the characteristic wastes (from Table 5) for which stabilization was used to determine required nonwastewater concentration-based treatment standards. Note that there are no total composition $(\mathrm{CCW})$ standards associated with these nonwastewater species; rather, concentration standards are expressed as CCWE, as determined by TCLP. The specified nonwastewater treatment standard for waste category $\mathrm{D} 007$ of a chromium concentration of $5.0 \mathrm{mg} / \mathrm{L}$, as CCWE, is based on chromium reduction and/or stabilization. Consequently, if this waste category were subjected to direct stabilization, the technology should incorporate chromium reduction as part of the stabilization process. One example of this approach would be the use of a grout-containing granulated blast furnace slag. In the context of the Final Waste Forms Project, Table 6 provides a list of characteristic nonwastewater wastes that are amenable to stabilization, in grout or other media, and the TCLP limits become product performance criteria.

Table 6. TCLP concentration standards for characteristic wastes based on stabilization as BDAT

\begin{tabular}{|c|c|c|c|c|c|c|}
\hline \multirow{2}{*}{ Waste code } & \multicolumn{6}{|c|}{ TCLP concentration standard (mg/L) } \\
\hline & $\mathbf{B a}$ & Cd & $\mathrm{Cr}$ & $\mathbf{P b}$ & Se & Ag \\
\hline D005 & 100 & & & & & \\
\hline D006 & & 1.0 & & & & \\
\hline D007 & & & 5.0 & & & \\
\hline D008-Lead category & & & & 5.0 & & \\
\hline D010 & & & & & 5.7 & \\
\hline D011 & & & & & & 5.0 \\
\hline
\end{tabular}

Although vitrification was the treatment technology used (i.e., BDAT) in establishing the treatment standard for D004-arsenic nonwastewaters of $5.0 \mathrm{mg} / \mathrm{L}$ in the waste extract (CCWE), any stabilization method may be used as long as the concentration-based standards 
are met. In the context of the Final Waste Forms Project, this waste category is amenable to stabilization, in glass or other media, and a TCLP concentration of $5.0 \mathrm{mg} / \mathrm{L}$ becomes a waste form product performance criterion for this waste category. Note also that this waste category (nonwastewater) does not have a specified maximum total $\mathrm{CCW}$ for arsenic.

With the exception of the waste subcategory D001-High TOC Ignitable Liquids, the specified treatment standard for D001 and D002 waste categories includes deactivation (Table 5). EPA defines stabilization as one of the BDATs for deactivation for these two waste categories. Consequently, these two waste categories can be considered candidates for stabilization, provided that the $S / S$ process used effectively deactivates the waste and that dilution is not used as a substitute for adequate treatment. One important point to consider is the required TCLP treatment standard for characteristic selenium nonwastewaters (D010). The treatment standard of $5.7 \mathrm{mg} / \mathrm{L}$ in the TCLP leachate is consistent with selenium standards for listed wastes (see Sect. 3.3). However, the hazardous characteristic toxicity level, as $\mathrm{CCWE}$, for selenium is $1.0 \mathrm{mg} / \mathrm{L}$. Therefore, at the higher concentration standard $(5.7 \mathrm{mg} / \mathrm{L})$ the waste material would still require management as a hazardous waste, although the material could be land disposed. Consequently, if a waste is only hazardous because of its characterization as D010, then a performance criterion of $1.0 \mathrm{mg} / \mathrm{L}$, which would render the waste nonhazardous, will be specified.

\subsection{CONTAMINATED DEBRIS}

Contaminated debris (i.e., hazardous debris as defined by the EPA) represents a unique waste category. As defined by the EPA [40 CFR 268.2(g)],

debris means any solid material exceeding a $60 \mathrm{~mm}$ particle size that is intended for disposal and that is: 1) a manufactured object; or 2) plant or animal matter; or 3) natural geologic material. However, the following materials are not debris: 1) any material for which a specific treatment standard is provided in Subpart D, Part $268 ; 2$ ) process residuals such as smelter slag and residues from the treatment of waste, wastewater, sludges or air emission residues; and 3) intact containers of hazardous waste that are not ruptured and that retain at least $75 \%$ of their original volume. A mixture of debris that has not been treated to the standards provided by 40 CFR 268.45 and other material (such as soils and sludge) is subject to regulation as debris if the mixture is comprised primarily of debris, by volume, based on visual inspection.

Note that while concrete generally may be classified as debris, cementitious or pozzolanic stabilized hazardous wastes are specifically excluded from this waste category.

Per 40 CFR 268.2(h),

hazardous debris means debris that contains a hazardous waste listed in subpart $D$ of part 261 , or that exhibits a characteristic of hazardous waste identified in subpart $C$ of part 261.

Certain debris that is contaminated with a listed waste (per subpart D of 40 CFR 261) for which EPA has established a treatment standard (but no required specific treatment 
technology) and debris exhibiting the characteristic(s) (per Subpart C of 40 CFR 261) of ignitability, corrosivity, reactivity, or toxicity may be treated to meet the alternative debris treatment standards adopted under the debris rule.

Per 40 CFR 268.40(b),

a restricted waste for which a treatment technology is specified under 40 CFR 268.42(a) ("Treatment Standards Expressed as Specified Technologies") or hazardous debris for which a treatment technology is specified under 40 CFR 268.45 ("Treatment Standards for Hazardous Debris") may be land disposed after it is treated using that specified technology or an equivalent method approved ... under the procedures set forth in 40 CFR 268.42(b).

These treatment standards are summarized in Appendix A, Table 5, and Appendix C.

Under the rule, EPA has identified 17 alternative treatment tect $\ldots$. igies as BDAT for hazardous debris (Appendix C). These are variants of the following .echnology groups: (1) extraction; (2) destruction; and (3) immobilization, for which performance and/or design requirements for the technologies designated as BDAT are established. Hazardous debris can be treated by one or more of the specified technologies for each "contaminant subject to treatment" defined as (1) the constituents for the listed waste that are subject to the LDRs found in 40 CFR 268.41 "Treatment Standards Expressed as Concentrations in Waste Extract") and 268.43 ("Treatment Standards Expressed as Waste Concentrations"), as summarized in Appendix A; (2) the RCRA hazardous waste constituent(s) for which the debris fails the Extraction Procedure toxicity characteristic, in addition to any other characteristic that causes the debris to be hazardous (ignitability, corrosivity, reactivity), as summarized in Table 5; and (3) cyanide or sulfide if debris exhibits reactivity because of the presence of those constituents.

Hazardous debris that is treated by a prescribed extraction or destruction technology and that subsequently does not exhibit a characteristic is excluded from Subtitle $\mathbf{C}$ regulation (i.e., may be considered as no longer hazardous and therefore solely a radioactive waste). Separation of treated debris from all treatment residues, including soil, waste, or other nondebris material that could adhere to the debris surface, is required prior to exclusion from Subtitle C. However, for debris treated by thermal desorption, biodegradation, chemical oxidation and reduction and for thermal destruction of debris contaminated with dioxin-listed wastes, the treated debris remains subject to Subtitle $C$ unless a successful "Equivalent Technology" demonstration is made under $\mathbf{4 0}$ CFR 268.42. Hazardous debris treated solely by a prescribed immobilization technology remains regulated by Subtitle C.

Alternatively, hazardous debris may be treated to meet the existing waste-specific treatment standards for the waste contaminating the debris (i.e., LDRs), but, with the noted exception of debris that is hazardous because of the presence of a characteristic waste and no longer exhibits a hazardous characteristic, the treated debris must then still be managed and disposed of as hazardous waste (in a Subtitle $C$ facility). Thus, hazardous debris must either be treated by specified technologies based on the type of debris and type of contaminant present (see Appendix C) or, as an alternative, meet the LDRs treatment standards for the specified prohibited listed or characteristic waste with which it is contaminated (see Appendix A and Table 5), or the regulatory agency may determine that 
the treated debris no longer contains hazardous constituents. The primary difficulty of implementing waste-specific treatment standards lies in obtaining representative sampling of the treated debris to document compliance with the concentration-based waste-specific standards prior to disposal in a Subtitle $C$ land disposal unit.

Note that residues (soil, wastewater, and nonwastewater) from the treatment of hazardous debris are subject to the waste-specific treatment standards (LDRs) for the waste contaminating the debris. The residual must be treated to these standards for all BDAT constituents specified in 40 CFR 268.41, 268.42, and 268.43 for the waste (see Appendix A and Table 5). Liquids that separate from debris prior to treatment must be managed as hazardous waste. Free liquids cannot be present in debris that is macroencapsulated or sealed and cannot be present in debris that has been microencapsulated. (Note that the term "microencapsulation" used in this section corresponds to the term "stabilization" in the context of the Final Waste Forms Project.)

Radioactive hazardous (i.e., mixed waste) debris is subject to debris treatment standards, except in the case where specific treatment standards have been established in 40 CFR 268.42 [e.g., for radioactive lead solids $>60 \mathrm{~mm}$, which are excluded per 40 CFR 268.2(g) from definition as debris and are thus subject to waste-specific treatment standards]. Per 40 CFR 268.42(d), radioactive hazardous mixed wastes with treat nent standards specified in Table 3 of that section ("Technology-Based Standards for Specific Radioactive Hazardous Mixed Waste") are not subject to any treatment standards specified in 40 CFR 268.41 or 268.43 or Table 2 of 268.42 ("Technology-Based Standards by RCRA Waste Code"). Radioactive hazardous mixed wastes not subject to treatment standards in Table 3 of 40 CFR 268.42 remain subject to all applicable standards specified in 40 CFR 268.41, 268.43, and Table 2 of 268.42. Hazardous debris containing radioactive waste is not subject to the treatment standards specified in Table 3 of 40 CFR 268.42 but is subject to the treatment standards specified in 40 CFR 268.45 .

In summary, based on these definitions, hazardous waste for which EPA has established a specified treatment technology is not debris. For example, the waste category D008-Radioactive lead solids (Table 5)-has a specified treatment technology (macroencapsulation) and therefore is not debris regardless of particle size. The LDRs, discussed in Sects. 3.1-3.4, apply only to debris contaminated with hazardous wastes for which treatment standards have been established or that exhibits a characteristic for which a treatment standard has been established.

Numerous options for treatment are available for debris, depcnding on the type of debris and waste contaminant. The most desirable option is to treat debris so as to allow its reclassification as nonhazardous waste. Most listed and/or characteristically hazardous debris can be treated using specified debris treatment technologies: extraction, destruction, or immobilization (Appendix C). After treatment to meet the performance, design, and operating standards of an approved extraction or destruction technology and provided that the treated debris exhibits no characteristics of hazardous waste (see Sect 3.4), the debris may not subsequently have to be managed as a hazardous waste and can therefore be land disposed in a Subtitle D facility or returned to the natural environment. This scenario does not apply to hazardous debris contaminated with waste(s) for which a specified technology has been established as the treatment standard. 
Alternatively, debris may be treated to meet the existing treatment standards (i.e., concentration-based limits) for the specific waste or waste constituent(s) with which it is contaminated. However, in this case the treated debris must still be managed as a hazardous waste. A third option is for the debris to be managed as a hazardous waste in accordance with the contained-in policy. Although numerous treatment/disposal options are potentially available for contaminated debris, the options with respect to $S / S$ are actually quite limited and are dependent on the waste code.

\subsubsection{Debris Containing Listed Waste with Specified Treatment Technologies as Treatment Standards}

If the debris is contaminated with one (or more) listed wastes that must be treated using a specified treatment technology (40 CFR 268.42), then the treatment options in Appendix C are not applicable. In this case, the debris must be treated using the specified technology, and the resulting product(s) must be disposed of as a hazardous waste.

\subsubsection{Debris Containing Listed Wastes with Specified Concentration-Based Treatment Standards}

If the debris is contaminated with one (or more) listed wastes with concentration-based treatment standards, then the debris can be treated using technologies presented in Appendix C. The treated debris must be treated by the specified technologies (Appendix C) based on the type of debris and type of contaminant(s) present or, as an alternative, meet the LDRs for the specified prohibited listed or characteristic waste with which it is contaminated. If the alternative treatment method (Appendix C) is used, the debris must be sampled and analyzed to ensure compliance with the treatment standards prior to disposal in a Subtitle C land disposal unit. Further, residues from treated debris are subject to the waste-specific concentration-based treatment standards for the waste contaminating debris.

Immobilization, as defined in the regulations pertaining to debris, corresponds to grout and organic binders under the Final Waste Forms Project. Treatment of hazardous debris by these two S/S technologies without prior treatment using prescribed extraction or destruction technologies, although acceptable, would result in a waste that would still have to be managed as hazardous waste within the waste codes of the original contaminants; that is, any debris contaminated with listed waste(s) that is treated solely by immobilization would have to be managed as hazardous waste unless delisted.

As discussed previously in this report and stated explicitly in Appendix C, EPA considers vitrification a thermal treatment technology. Consequently, it would appear that vitrification could potentially be used to render debris nonhazardous. However, prior to disposal as a nonhazardous waste, the treated debris must first be separated from treatment residues, and the treatment residues must continue to be treated as hazardous waste within the waste codes of the untreated wastes [40 CFR 268.45(d)(1)]. The EPA clearly defines treatment residues to include the vitrified product or waste form (57 FR 37234) utilizing the logic that "... .the original debris no longer exists and the residuals from soil or waste contaminating the debris are integral components of the slag and vitrified residue" (57 FR 37241). Consequently, as with immobilization (i.e., grout and organic binders), vitrification is an acceptable treatment method for hazardous debris but results in a waste form that would still have to be managed as hazardous according to the original contaminants' waste codes. 


\subsubsection{Debris Contaminated with Characteristic Waste}

The treatment standard for characteristically ignitable, corrosive, and reactive hazardous debris is deactivation. However, the standard must be achieved by use of treatment methods specific for other debris unless it can be demonstrated that the debris does not contain characteristically toxic constituents. Thus the same treatment standards apply for ignitable, corrosive, and reactive (ICR) debris as for other hazardous debris. Existing treatment standards, which may allow dilution for some characteristic wastes, may not be used for ICR debris: dilution is prohibited other than may occur as a result of using one of the designated treatment methods (see Appendix C). Identification of the hazardous constituents present is not required, as use of the specified technology is assumed to result in their adequate treatment.

Debris contaminated with material that is hazardous solely because of a characteristic (see Table 5) can be treated by either vitrification or immobilization (i.e., glass, grout, and organic binder); however, debris that contains a listed hazardous waste or contaminants that exhibit the Toxicity Characteristic in 40 CFR 261.24 must be treated by extraction or destruction technology. It must be treated to the performance, design, and operating standards specified for the type of alternate treatment standard utilized. If the treated hazardous debris and its residue meet these treatment standards and no longer exhibit a hazardous characteristic, then the debris may be disposed of as a nonhazardous waste (but still a radioactive waste).

Two notable exceptions to this scenario exist:

1. Any debris considered reactive because of the presence of cyanides (e.g., D003-Reactive cyanides category) must be treated by one of the specified technologies for which the treatment standards can be achieved for cyanides (i.e., deactivation). Any residue from such treatment may not be land disposed until cyanide is treated to levels established in Table CCW of 40 CFR 268.43 (see Table 5). One option is pretreatment by a chemical destruction method such as alkaline chlorination (Appendix C). Vitrification may represent a potential direct stabilization option, in that the process of vitrification, which is considered a thermal destruction technology in this context and would therefore be expected to destroy cyanides, may be acceptable to EPA under an "Equivalent Technology" demonstration. In the event this is not the case, vitrification and other direct stabilization options would be considered to constitute impermissible dilution.

2. The other exception is debris that is considered by the EPA to be inherently hazardous (57 FR 37236-37237). Inherently hazardous debris includes debris that has been fabricated from D004-D011 metals and that is toxic per the TCLP in its original state. In this case, only two options are available:

a. Treatment by immobilization followed by disposal, as a hazardous waste, in a Subtitle $C$ facility. If contaminated by listed waste, that waste must also be treated by one of the prescribed treatment methods. Pretreatment for these contaminants may not be required prior to immobilization if the performance standards for the immobilization technology can be achieved without such prior treatment. Residues from treating inherently hazidous debris require no further treatment unless (1) they exhibit a prohibited hazardous waste characteristic or (2) they result from treating listed constituents, in which case the residues are subject to the 
concentration-based standards applicable to that listed waste. If debris is pretreated by a prescribed technology to destroy/remove the listed waste prior to immobilization, residues from that pretreatment would require subsequent treatment to applicable concentration-based standards, but residues from subsequent immobilization would not, unless they exhibit a characteristic.

b. Recycling as Scrap Metal. LDRs do not apply to inherently hazardous debris that is scrap metal being recycled, even if contaminated with listed constituents. Recycled metal residues from processing remain regulated under the derived-from rule and are subject to LDRs before disposal, unless the debris has first been treated by a prescribed technology (whose residues would themselves still be considered hazardous), in which case subsequent processing residues would be nonhazardous unless they exhibit a characteristic.

\subsubsection{Impact on Phase I Performance Criteria}

Stabilization/solidification (i.e., "immobilization" in glass, grout, and/or organic binders) cannot be used to render contaminated debris nonhazardous for listed wastes and therefore cannot be a primary tieatment option. On the other hand, S/S can be used to render debris contaminated with characteristic waste nonhazardous. It must be noted that the generator or treater of the debris must demonstrate to the regulatory agency that the debris does not contain toxic constituents for the treated debris to be excluded from Subtitle $\mathrm{C}$ management.

Clearly, however, the waste form technologies being addressed by this project are considered potentially acceptable treatment options for contaminated debris, although the product may remain a hazardous waste. The performance criteria (with respect to the Final Waste Forms Project) for the resulting waste form becomes the same as that for the waste categories of the debris contaminant(s) that have been discussed previously. 


\section{TOXIC SUBSTANCES CONTROL ACT}

The special category of waste contaminated with $\mathrm{PCBs}$ is regulated under the Toxic Substances Control Act (TSCA) (40 CFR 761). The effective treatment standard for PCB wastes is $\leq 2 \mathrm{ppm}$ PCBs for solids and nonaqueous liquids and $\leq 3 \mathrm{ppb}$ PCBs in aqueous wastewaters.

A major precept of the PCB regulations is the antidilution provision found in 40 CFR 761.1, which states "No provision [of the PCB regulations, especially disposal] may be avoided as a result of any dilution [intentional or not]..." Thus, dilution of any kind to avoid disposal requirements for PCBs is not allowed. Wastes known to be derived from a 50-ppm or greater PCB source must be disposed of as prescribed in 40 CFR 761, Subpart D, although actual concentrations in the waste stream may be $<50 \mathrm{ppm}$ or even nondetectable. Thus, PCB wastes must be managed based on the source concentration. Rinsing of PCB containers or equipment for decontamination purposes is authorized under $40 \mathrm{CFR} 761.79$, provided the rinsates are managed as liquid PCB waste based on the source concentration.

\subsection{PCB LIQUIDS}

In general, PCB liquids (e.g., mineral oil dielectric fluid, liquid PCBs) at concentrations of $50 \mathrm{ppm}$ or greater but $<500 \mathrm{ppm}$ must be disposed of either by

1. combustion in an EPA TSCA-approved incinerator that conforms to the requirements of 40 CFR 761.70;

2. combustion in an EPA TSCA-approved high-efficiency boiler that conforms to the operational performance requirements of
a. $\quad 40$ CFR 761.60(a)(2)(iii), for mineral oil dielectric fluid, or
b. $\quad 40$ CFR 761.60(a)(3)(iii), for PCB liquids; or

3. in a chemical landfill that conforms to the requirements of 40 CFR 761.75 .

Used oil to be burned for energy recovery is assumed to contain quantifiable levels of PCBs (i.e., 2 ppm) unless analysis shows otherwise. Per EPA Policy 6-PCB-4, industrial sludges or slurries containing PCBs at 500 ppm or greater must be disposed of by incineration. PCB industrial sludges or slurries generated by processing liquid PCBs must be disposed of in the same manner as required for the original liquid PCBs (i.e., high concentration requirements).

PCB liquids containing $>500 \mathrm{ppm}$ PCBs or wastes that were derived from a PCB source with PCB concentration $>500 \mathrm{ppm}$ must be incinerated or else disposed of by an EPA TSCA-approved alternate method of disposal.

Bulk liquids not exceeding $500 \mathrm{ppm}$ may be disposed of provided such waste is pretreated and/or stabilized (e.g., chemically fixed, evaporated, mixed with dry inert absorbant) to reduce 
its liquid content or increase its solids content so that a nonflowing consistency is achieved to eliminate the presence of free liquids prior to final disposal. A PCB container of liquid PCBs with a concentration between 50 and 500 ppm may be disposed of if each container is surrounded by an amount of inert sorbant material capable of absorbing all of the liquid contents of the container. While landfill disposal of liquid PCBs wastes is thus theoretically possible under the regulations, as a practical matter, few, if any, such permitted outlets exist, and such disposal will not be further considered as a viable option under this project.

\subsection{PCB SOLDS}

Nonliquid PCBs (e.g., equipment, contaminated soil, rags, debris, dredged materials, and municipal sewage treatment sludges) at PCB concentrations of $50 \mathrm{ppm}$ or greater or which originate from a PCB source of $50 \mathrm{ppm}$ or greater must be disposed of either by incineration or in chemical landfills. PCB Items (e.g., transformers, capacitors, hydraulic machines, electrical equipment, and containers) with concentrations at $500 \mathrm{ppm}$ or greater must either be incinerated or disposed of in a chemical waste landfill, provided that all free-flowing liquids have been thoroughly drained prior to the article's disposal and that the drained liquids are disposed of in an incinerator. PCB Articles with a concentration between 50 to 500 ppm must be disposed of by draining all free liquid and disposing of the liquid in an incinerator, high-efficiency boiler, or chemical waste landfill (see requirements for PCB liquids, above). The drained article is not regulated under TSCA and may be disposed of in a municipal landfill. However, this wording is being changed in the PCB regulations. The PCB Article will be regulated under TSCA. Additional options, such as smelting, are allowed for drained $<500$-ppm PCB Articles. It is unlikely any municipal landfill would or could accept these Articles.

Chemical waste landfills must meet the siting and design requirements of $40 \mathrm{CFR}$ 761.75(b) prior to acceptance of PCB wastes for disposal. PCBs and PCB Items shall be placed in a landfill in a manner that prevents their damage and such that chemically incompatible wastes (including organic solvents) will be segregated from the PCBs.

\subsection{PCB SPILL CLEANUP POLICY REQUIREMENTS}

The EPA PCB spill cleanup policy, established in 40 CFR 761, Subpart G, applies to spills of $50 \mathrm{ppm}$ or greater or from a source of PCBs of $50 \mathrm{ppm}$ or greater (because of the antidilution rules). The concentration of PCBs spilled is determined by the PCB concentration in the material spilled as opposed to the concentration of PCBs in the material onto which the PCBs were spilled. Where a spill of untested mineral oil occurs, the oil is presumed to contain $>50$ ppm but $<500$ ppm PCBs. The policy does not affect cleanup standards imposed under other federal statutory authorities, including, but not limited to, the Clean Water Act, RCRA, and the Comprehensive Environmental Response, Compensation, and Liability Act/Superfund Amendments and Reauthorization Act (CERCLA/SARA). Where more than one requirement applies, the more stringent standard must be met.

For spills involving $<1 \mathrm{lb}$ of low-concentration $(<500-\mathrm{ppm}$ ) PCBs by weight (equivalent to $<270$ gal of untested mineral oil containing $<500$-ppm PCBs), solid surfaces must be double washed/rinsed (per 761.123) and indoor residential surfaces (other than vault areas) cleaned to $10 \mu \mathrm{g} / 100 \mathrm{~cm}^{2}$; all soil with visible traces plus one lateral foot must be excavated 
and the ground returned to its original configuration by backfilling with clean soil (i.e., containing <1 ppm PCB).

Rec irements for cleanup of high-concentration (>500-ppm) PCB spills and lowconcentration soils involving $1 \mathrm{lb}$ or more by weight are as follows:

1. For outdoor electrical substations (per 761.123): Contaminated solid surfaces must be cleaned to $100 \mu \mathrm{g} / 100 \mathrm{~cm}^{2}$; soil contaminated must be cleaned to either $25 \mathrm{ppm}$ PCBs by weight or to $50 \mathrm{ppm}$ by weight provided that a label or notice is visibly placed on the rea. EPA may establish an alternative level based on potential impacts of meeting the above standards to the integrity of the equipment at the facility. At the time the facility is converted to another use, the spill site must be cleaned to the unrestricted access requirements below.

2. For restricted access areas (per 761.123): High-contact solid surfaces (see 761.123) and low-contact, indoor, impervious solid surfaces must be cleaned to $10 \mu \mathrm{g} / 100 \mathrm{~cm}^{2}$; lowcontact, indoor, nonimpervious solid surfaces must be cleaned to either $10 \mu \mathrm{g} / 100 \mathrm{~cm}^{2}$ or to $100 \mu \mathrm{g} / 100 \mathrm{~cm}^{2}$ and encapsulated (the encapsulation option must be approved by the EPA, who has the authority to disallow the encapsulation option); low-contact outdoor surfaces must be cleaned to $100 \mu \mathrm{g} / 100 \mathrm{~cm}^{2}$; and soil contaminated by the spill must be cleaned to 25-ppm PCBs by weight. At the time the facility is converted to another use, the spill site must be cleaned to the unrestricted access requirements below.

3. For nonrestricted access areas (per 761.123): Indoor solid surfaces and high-contact outdoor solid surfaces must be cleaned to $10 \mu \mathrm{g} / 100 \mathrm{~cm}^{2}$; indoor vault areas and lowcontact, outdoor, impervious solid surfaces must be cleaned to $10 \mu \mathrm{g} / 100 \mathrm{~cm}^{2}$; lowcontact, outdoor, nonimpervious solid surfaces must be cleaned to either $10 \mu \mathrm{g} / 100 \mathrm{~cm}^{2}$ or cleaned to $100 \mu \mathrm{g} / 100 \mathrm{~cm}^{2}$ and encapsulated (the encapsulation option must be approved by the EPA, who has the authority to disallow the encapsulation option); and soil contaminated by the spill must be decontaminated to 10-ppm PCBs by weight provided that the soil is excavated to a depth of 10 in. The excavated soil will be replaced by clean soil, that is, soil containing $<1 \mathrm{ppm}$ PCBs, and the spill site will be restored.

\subsection{PCB-CONTAMINATED DEBRIS}

Hazardous debris that is also a PCB waste under 40 CFR Part 761 must comply with applicable PCB requirements and debris treatment standards by satisfying the more stringent applicable requirements. Thus, treatment standards for hazardous debris apply to debris contaminated with PCBs and RCRA hazardous waste.

Debris treated to performance standards by Extraction or Destruction technology (and which does not exhibit a characteristic) remains subject only to TSCA regulation. Debris treated solely by immobilization remains subject to RCRA and TSCA. Disposal of debris contaminated by PCBs is regulated under 40 CFR 761.60, and debris resulting from cleanup of PCB spills is subject to PCB Spill Cleanup Policy under 40 CFR 761.125. 


\subsection{IMPACT ON PERFORMANCE CRITERIA}

Based on this brief summary of TSCA, it is clear that the preferred treatment option for PCB-contaminated waste is thermal destruction. Because of the antidilution provisions of TSCA and based on past policy, it is doubtful that generic approaches to S/S as sole treatment methods would receive approval as a disposal option for PCBs. Typically, EPA disposal approvals under TSCA are specific not only to the type of PCB waste, but also to the person, location, and formal approval application. However, alternative methods specific to the type of PCB waste may be approved by EPA under the provisions of 40 CFR 761.60(e) for disposal of PCB wastes.

Other PCB-contaminated waste is not inherently a RCRA hazardous waste. Disposal of PCB-containing dielectric fluid and equipment regulated under 40 CFR 761 that are hazardous only due to failure to pass TCLP (i.e., characteristically toxic) are exempt from regulation under RCRA. However, PCB waste can become regulated under RCRA if

1. the waste is mixed with (or contains) a listed hazardous waste (Sect. 3.3) and/or

2. the waste exhibits a characteristic of a hazardous waste (Sect. 3.4).

In either of these two cases, the waste becomes a "California List Waste" (Sect. 3.2) provided that the waste is a liquid as determined in a Paint Filter Test and the PCB concentration is $\geq 50 \mathrm{ppm}$. The PCBs must be disposed of (i.e., treated) per TSCA requirements, and the RCRA hazardous constituents must be treated according to requirements in 40 CFR Parts 264, 265, and 258.

The assumption is made in this report that PCBs will be destroyed to acceptable levels as prescribed in TSCA prior to becoming a feed stream to the Final Waste Forms Project. Performance criteria of the residue will be determined by its RCRA waste codes (or categories), which have been discussed previously. Alternative methods of PCB disposal may be pursued through submission of an application for disposal approval with the EPA Regional Administrator, through submission of an alternative disposal proposal by means of an existing compliance agreement (e.g., the Uranium Enrichment Federal Facility Compliance Agreement for PCBs), or through comments to the anticipated PCB rulemaking under TSCA, expected in mid-1994. Such alternative methods are being considered by EPA to be codified in this rulemaking. Treatment to meet LDRs could be pursued for approval as PCB disposal provided the treatment achieved the performance standard ( $<2 \mathrm{ppm}$ ) for PCB disposal under 40 CFR 761.60(e) and did not constitute dilution. Other alternative methods to dispose of PCBs prior to treatment to meet LDRs may also be pursued by the means described above. 


\section{NUCLEAR REGULATORY COMMISSION REGULATIONS}

It is recognized that DOE is not specifically regulated by the Nuclear Regulatory Commission (NRC). However, it is appropriate to address applicable NRC regulations in this report for three reasons:

1. The disposal plans for ORR mixed wastes have not been finalized at this time. One option being considered is off-site commercial disposal. Commercial disposal facilities will be directly regulated by the NRC.

2. Many DOE sites (e.g., Hanford), although not directly regulated by NRC, are utilizing NRC performance criteria for waste forms, and ORR should consider consistency with this approach.

3. EPA is beginning to specifically address mixed wastes (e.g., D008-Radioactive lead solids). Although it is impossible to predict the future course of regulations, it is reasonable to assume that EPA will utilize NRC requirements/regulations as resource documents in the development of future regulations.

This section will present the waste form performance criteria that are derived from the NRC regulations on the low-level radioactive waste (LLW) portion of mixed waste (10 CFR 61.1-61.83). First, applicable definitions are reviewed, including regulations that apply to each LLW classification. Next, the specific waste form performance criteria are detailed.

The goal of the NRC regulations is to limit public exposure to levels that present no unacceptable health risks. "Concentrations of radioactive material which may be released to the general environment in ground water, surface water, air, soil, plants, or animals must not result in annual dose levels" that exceed acceptable values (10 CFR 61.41). Stabilizing LLW forms can reduce radioactive constituent release rates and thereby prevent acceptable environmental concentrations from being exceeded.

\subsection{LLW CLASSIFICATIONS}

\subsubsection{General Description}

This section discusses the basis for the LLW classification and disposal regulations (10 CFR 61.55-61.56). LLW is radioactive material that is not high level waste, spent fuel, uranium or thorium mill tailings, or transuranic waste. Concentration limits for radionuclides of particular concern are listed in Tables 7 and 8. These concentration limits are used to differentiate between the difterent classes of LLW. LLW is divided into Class A, B, C, or not suitable for disposal (i.e., Greater-than-Class C) classification categories. The specific waste form performance and disposal criteria applicable to an individual waste are determined by the waste's classification. The purpose of this classification system is to correlate the safety requirements to the relative risk of each specific waste type. 
Table 7. NRC radionuclide concentrations used to classify low-level radioactive wastes: long-lived radionuclides

\begin{tabular}{lc}
\hline \multicolumn{1}{c}{ Long-lived radionuclides } & Concentration $\left(\mathrm{Ci} / \mathrm{m}^{3}\right)$ \\
\hline${ }^{14} \mathrm{C}$ & 8 \\
${ }^{14} \mathrm{C}$ in activated metal & 80 \\
${ }^{59} \mathrm{Ni}$ in activated metal & 220 \\
${ }^{94} \mathrm{Nb}$ in activated metal & 0.2 \\
${ }^{90} \mathrm{Tc}$ & 3 \\
${ }^{1 / 1}$ & 0.08 \\
$\mathrm{Alpha-emitting} \mathrm{transuranic} \mathrm{nuclides} \mathrm{with} \mathrm{a}$ & $100^{\circ}$ \\
half-life greater than 5 years & $3,500^{\circ}$ \\
${ }^{241} \mathrm{Pu}$ & $20,000^{\circ}$ \\
\hline${ }^{242} \mathrm{Cm}$ &
\end{tabular}

${ }^{a}$ Units are nanocuries per gram.

Source: 10 CFR 61.55, Table 1.

Table 8. NRC radionuclide concentrations used to classify low-level radioactive wastes: short-lived radionuclides

\begin{tabular}{lccc}
\hline & \multicolumn{3}{c}{ Concentration $\left(\mathrm{Ci} / \mathrm{m}^{3}\right)$} \\
\cline { 2 - 4 } Short-lived radionuclides & Col. 1 & Col. 2 & Col. 3 \\
\hline $\begin{array}{l}\text { Total of all nuclides with } \\
<5 \text {-year half-life }\end{array}$ & 700 & $a$ & $a$ \\
${ }^{3} \mathrm{H}$ & 40 & $a$ & $a$ \\
${ }^{60} \mathrm{Co}$ & 700 & $a$ & $a$ \\
${ }^{63} \mathrm{Ni}$ & 3.5 & 70 & 700 \\
${ }^{60} \mathrm{Ni}$ in activated metal & 35 & 700 & 7000 \\
${ }^{90} \mathrm{Sr}$ & 0.04 & 150 & 7000 \\
${ }^{137} \mathrm{Cs}$ & 1 & 44 & 4600 \\
\hline
\end{tabular}

a There are no limits established for these radionuclides in Class B or C. Practical considerations, such as the effects of external radiation and internal heat generation on transportation, handling, and disposal, will limit the concentrations for these wastes. These wastes shall be Class B unless the concentrations of other nuclides in Table 8 determine the waste to be Class $\mathrm{C}$ independent of these nuclides.

Source: 10 CFR 61.55, Table 2. 
The Class A waste category includes those LLW vastes that present the least hazard to the public. From among the radionuclides of concern, Class $A$ wastes contain insignificant amounts of the longer- and shorter-lived radionuclides found in Tables 7 and 8 respectively. Class A waste only requires predisposal stabilization (i.e., raw waste treatment to produce a stable waste form) if it has an unacceptable liquid content, as defined in Sect. 5.2.1, or is to be disposed of without segregation from Class B or C wastes. Class B waste also contains insignificant concentrations of the longer-lived radionuclides of concern but contains higher concentrations of the shorter-lived radionuclides than Class $A$ waste and therefore presents a greater potential risk to the public. Consequently, Class B wastes must be stabilized prior to disposal. The radionuclide concentrations of Class A and B wastes decay to levels that no longer represent a significant radiation hazard 100 years after disposal. Consequently, there is a corresponding requirement for 100 years of disposal site institutional control in order to prevent an individual from inadvertently entering the buried LLW and being exposed to it.

A waste $:$ classified as Class $\mathrm{C}$ waste if it contains any one of the following:

1. Significant amounts of the longer-lived radionuclides of concern.

2. A relatively large concentration of the shorter-lived radionuclides of concern.

3. A mixture of short-lived radionuclides whose associated sum total risk exceeds that allowable in Class B waste.

Class $\mathrm{C}$ wastes require 500 years to decay to levels that present an acceptable hazard to an intruder. Consequently, Class $\mathrm{C}$ waste requires special disposal precautions in addition to predisposal stabilization. Such disposal precautions may include deeper burial or 500 -year inadvertent intrusion barriers. The stabilized waste forms for both Class B and C wastes should be designed to maintain "gross physical properties and identity, over 300 years."

Finally, wastes whose long- or short-lived radionuclide content exceeds the maximum allowable for Class $\mathrm{C}$ waste is designated unsuitable for shallow land burial regardless of waste stability. Proposals for disposal of these wastes may be submitted to the NRC for approval pursuant to $10 \mathrm{CFR} 61.58$.

\subsubsection{Technical Definitions (10 CFR 61.55)}

Appropriate waste classification categories are assigned by a two-step sequential comparison of the waste's radionuclide content to the concentration limits listed in Tables 7 and 8. The overall waste classification assigned is the more restrictive result of the two steps. For example, if a waste is Class A per step one and unsuitable for near-surface disposal per step two, then the waste must be treated as unsuitable for near-surface disposal. Each individual waste radionuclide concentration is compared to the corresponding concentration limit found in the tables. For wastes cuntaining two or more of the radionuclides listed in Tables 7 and 8, the sum of the fractions rule must be applied, as described in Sect. 5.1.2.3.

\subsubsection{First classification step}

The first step in classifying waste is to compare the waste's radionuclide concentrations to the long-lived radionuclide concentration limits listed in Table 7. If the waste does not contain any Table 7 radionuclides, then the waste is Class $A$ per step one. If the waste contains radionuclides listed in Table 7, classification shall be determined as follows: 
1. If the concentration does not exceed 0.1 times that listed in Table 7 , then the waste is Class A per step one.

2. If the waste exceeds 0.1 times the concentration found in Table 7 but does not exceed the listed value, the waste is, at a minimum, Class $C$ per step one but may be unsuitable for disposal depending upon classification step two, described in Sect. 5.1.2.2.

3. If the waste exceeds the value listed in Table 7, it is not suitable for near-surface disposal regardless of the results of classification step two.

4. For wastes that contain a mixture of more than one of the radionuclides listed in Table 7, the sum of the fractions rule must be invoked to determine classification per step one (see Sect. 5.1.2.3).

\subsubsection{Second classification step}

The second classification step requires comparison of the waste's radionuclide concentrations with the short-lived radionuclide concentrations listed in Table 8. Waste not already classified in step one, per Sect. 5.1.2.1, as unsuitable for disposal must be further classified by comparison with Table 8 concentrations as follows:

1. If the waste does not contain any of the radionuclides listed in Table 8, then it is Class A waste per step two.

2. If the waste contains Table 8 individual radionuclide concentrations less than the values listed in column 1 and the sum of the fractions (see Sect. 5.1.2.3) is less than 1.0 (using column 1 concentrations as the divisor) for wastes with two or more of the Table 8 radionuclides, then the waste is still Class A per step two.

3. If the waste contains Table 8 individual radionuclide concentrations between the values listed in columns 1 and 2 and the sum of the fristiuns (see Sect. 5.1.2.3) is less than 1.0 (using column 2 concentrations as the divisor) for wastes with two or more of the Table 8 radionuclides, then the waste is Class B per step two.

4. If the waste contains Table 8 individual radionuclide concentrations between the values listed in columns 2 and 3 and the sum of the fractions (see Sect. 5.1.2.3) is less than 1.0 (using column 3 concentrations as the divisor) for wastes with two or more of the Table 8 radionuclides, then the waste is Class C per step two.

5. If the waste contains Table 8 individual radionuclide concentrations greater than the values listed in column 3 or the sum of the fractions (see Sect. 5.1.2.3) is greater than 1.0 (using column 3 concentrations as the divisor) for wastes with two or more of the Table 8 radionuclides, then the waste is classified as not generally acceptable for nearsurface disposal.

\subsubsection{Sum of fractions}

For a waste with a combination of two or more of the radionuclides listed in a single table (i.e., each table is treated separately), the sum of the fractions method is used. The fractional contribution of a given radionuclide is calculated by dividing its concentration in the 
waste by the limiting concentration of interest listed in the table (i.e., the corresponding concentration in a chosen column). This calculation is repeated for each radionuclide in turn, using a consistent set of table concentrations limits as divisors (i.e., all found in a single column of the table). If an individual fraction is greater than 1.0, then the next higher column of limits must be used as the divisor for all the radionuclides. All the fractions are then summed. This sum must also be less than 1.0 if the waste is to be classified by the limits of the column used. If the sum is greater than 1.0, the next higher column of concentration limits must be used and the process repeated until the sum of the fractions is less than 1.0. The column with the lowest concentration levels, which result in a sum of the fractions less than 1.0 , is the column to be used to classify the waste.

\subsection{REQUIRED LLW WASTE FORM CHARACTERISTICS}

To satisfy the NRC that a waste treatment process will consistently produce acceptable waste forms, a treatment plant-specific process control program (PCP) must be submitted and approved. A detailed description of the NRC requirements for a PCP is beyond the scope of this document. However, there are specific waste form performance criteria that can be gleaned from the regulations and used to determine the feasibility of a technology for treating a waste to produce a potentially acceptable waste form. This section summarizes the NRC waste form requirements presented in 10 CFR 61.55-61.56 and the NRC Waste Form Technical Position Paper. The position paper provides guidelines for quantifying requirements set forth in $10 \mathrm{CFR}$ 61.56. The requirements presented are for the waste or waste container. For the purposes of this document, the requirements are interpreted to be properties that the waste form itself should possess in order to be considered acceptable. The intent is to provide specific performance criteria by which candidate waste forms can be evaluated for Phase I treatability studies.

The first set of requirements discussed apply to all LLW, while the second set, stability requirements, apply only to Class $B$ and $C$ wastes, with the addition of Class $A$ waste that is to be disposed of without segregation from Class B and C wastes. LLW management and disposal regulations are designed to protect public health by minimizing public exposure through isolation and containment of waste. Thus, stabilization of the waste is a tool to minimize exposure.

\subsection{Requirements for All LLW Classifications}

The following are minimum required waste form characteristics for all classes of LLW:

1. Liquid waste must be solidified or packaged in sufficient absorbant material to absorb twice the volume of liquid [10 CFR 61.56(a)(2)].

2. Solid waste must contain as little free-standing and corrosive liquids as is practicable. At a maximum, free-standing and corrosive liquids will not exceed $1 \%$ of the waste volume when the waste is disposed of in a container designed to provide stability or $0.5 \%$ of the waste volume when solidified [10 CFR 61.56(a)(3) and 61.56(b)(2)]. Free-standing liquid measurements should be made in accordance with test method American Nuclear Society (ANS) 55.1. 
3. The waste must not readily be explosive or predisposed to rapid decomposition reactions at normal operating pressures and temperatures [10 CFR 61.56(a)(4)].

4. To protect personnel during waste handling, waste forms cannot contain, or be able to generate, toxic gases. Properly packaged waste gases are an exception to this rule [10 CFR 61.56(a)(5) and 61.56(a)(7)].

5. Waste forms shall be nonflammable [10 CFR 61.56(a)(6)].

6. Gaseous wastes must be packaged at pressures not to exceed $1.5 \mathrm{~atm}$ at $20^{\circ} \mathrm{C}$. The total activity per package may not exceed $100 \mathrm{Ci}$ [10 CFR 61.56(a)(7)].

7. Waste forms must minimize the hazards from biological, pathogenic, or infectious materials found in the urtreaied waste [10 CFR 61.56(a)(8)].

\subsubsection{Waste Form Stability Requircments}

Stabilized wastes must have structural stability as defined in the guidelines below. "Structural stability is intended to ensure that the waste does not degrade and (a) promote slumping, collapse, or other failure of the cap or cover over a near-surface disposal unit and thereby lead to water infiltration, or (b) impart a substantial increase in surface area of the waste form that could lead to an increase in leach rates." It should be noted that [10 CFR 61.56(b)(1)] structural stability can be provided by placing the waste in a disposal container or structure that provides stability after disposal or by the waste form itself. In 10 CFR 61.56(b)(1), a structurally stable waste form is defined as one that "will generally maintain its physical dimensions and its form under the expected disposal conditions such as weight of overburden and compaction equipment, the presence of moisture and microbial activity, and internal factors such as radiation effects and chemical changes." Class A waste need only meet the minimum requirements described in 10 CFR 61.56(a) (see Sect. 5.2.1). However, Class B and C wastes must meet the minimum requirements in 10 CFR 61.56(a) and the stability requirements in $10 \mathrm{CFR}$ 61.56(b) (described in this section). If Class $A$ wastes also meet the stability requirements, then it need not be segregated from Class $B$ and $\mathrm{C}$ wastes for disposal [10 CFR 61.55(a)(2)(ii)]. Specific test methods, presented in this and subsequent sections, to determine waste form stability are taken from the technical position paper.4

1. Compressive Strength: Solidified waste should have the maximum compressive strength practicable but, at a minimum, must have a compressive strength of 60 psi when tested in accordance with ASTM C39 (Ref. 6) (see Sect. 5.2.3 for standards specific to cementitious waste forms). Bituminous products should be tested in accordance with ASTM D1074.

2. Resistance to Thermal Degradation: Waste specimens should be resistant to thermal cycle degradation. Samples suitable for ASTM C39 or D1074 testing must be subjected to 30 thermal cycles, from -40 to $+60^{\circ} \mathrm{C}$, in a heating and cooling chamber in accordance with ASTM B553. ${ }^{8}$ Following the thermal cycling, the samples must demonstrate retention of their compressive strength (60 psi minimum). 
3. Radiation Stability: Wastes must demonstrate the ability to retain their compressive strength after being subjected to $10 \mathrm{E}+8$ rads or the maximum expected exposure level, whichever is greater.

4. Resistance to Biodegradation: Samples must retain their compressive strength after being tested in accordance with ASTM G21 (Ref. 9) and G22 (Ref. 10) and should also exhibit no visible culture growth.

For polymeric or bitumen waste forms, some culture growth is acceptable provided that

a. The growth does not relate to overall substrate integrity.

b. After removal of growth and drying of the samples, followed by repetition of ASTM G22 and G21, the G22 specimen shows no observable growth and the G21 specimen shows no growth greater than for the first G21 test.

c. After completion of the second test, compressive strength testing demonstrates that the samples retain the minimum compressive strength.

d. If unsatisfactory growth is observed, a 6-month test in accordance with the Bartha-Pramer method ${ }^{11}$ employing disposal representative soils must produce less than a $10 \%$ total carbon loss when extrapolated to $\mathbf{3 0 0}$ years and a full-size waste form.

5. Chemical Durability: Samples of sizes suitable for ASTM C39 and D1074 testing must demonstrate a 90-day leachability index greater than 6.0 and a subsequent retention of their compressive strength. The leach test should be performed in accordance with ANS $16.1,{ }^{12}$ with the addition of the following provisions:

a. Other leachates, including synthesized seawater (listed in ANS 16.1), should be used in addition to demineralized water.

b. All leach tests are performed for a minimum of 90 days.

c. Where practicable, radioactive tracers should be used in performing the leach tests.

6. Immersion Testing: Waste specimens must retain maximum practical compressive strength following immersion for a minimum period of 90 days. Immersion testing may be done in conjunction with leach testing. ${ }^{13}$

7. Free-Standing Liquid: Specimens must have less than $0.5 \mathrm{vol} \%$ free liquid, as measured by ANS 55.1. The liquid should have a pH between 4 and 11 .

8. Test Specimen-Actual Waste Form Correlation: The following testing of full-scale products, which may be fabricated with nonradioactive waste, must be performed to validate laboratory predictions:

a. Corc Testing: Test sections from cores of the anticipated full-scale products must be obtained and tested to determine the correlation to the small laboratory sample. Correlation testing must include 90 -day immersion tests on waste products formed 
from problem wastes, defined as those wastes that are the most to difficult incorporate into a consistent product.

b. Destructive Analysis: Full-scale waste products must be destructively analyzed to ensure that they are homogeneous "to the extent that all regions in the product can be expected to have compressive strengths comparable to lab scale specimens."

\subsubsection{Requirements Particular to Cement Waste Forms}

Unique chemical and physical interactions occur in cement-stabilized waste forms (i.e., grout in the context of this project). Therefore, the NRC has promulgated, in Appendix A to the Waste Form Technical Position Paper, ${ }^{4}$ a set of cement-specific waste form qualification criteria to supplement those discussed above. Only a summary of these requirements is presented here. To better understand the events and rationale leading to these requirements, the reader is encouraged to review the discussion found in the appendix to that document.

1. Compressive Strength: An ASTM C39 mean compressive strength of 500 psi is recommended for cementitious waste forms cured for a minimum of 28 days. The following requirements are stipulated in addition to ASTM C39:

a. Test specimens must be cylindrical with a 2- to 3-in. diam.

b. The length-to-diameter ratio (L/D) should be approximately equal to 2 .

c. A minimum of ten as-cured test specimens must be tested to determine the mean.

d. Compressive strength and/or penetrometer tests should be made after $24 \mathrm{~h}$ of curing for later comparison with actual PCP specimens.

2. Thermal Cycling: Specimens should be tested bare (i.e., not in a container). Specimens should be allowed to come to thermal equilibrium, as evidenced by the center temperature of at least one specimen per test group. Three specimens per waste formulation should be tested. Following 30 thermal cycles, the specimens should be examined visually and should be free of any evidence of significant cracking, spalling, or bulk disintegration. Visible evidence of significant degradation would be indicative of a failure of the test. Because it is not possible to provide a priori assessment of the significance of the visible defects, no definition of significant degradation is providedassessment of the significance of defects is left up to the tester. Photographic records of the defects should be kept. If no significant defects are visible, the specimen should be compression strength tested.

3. Irradiation Durability: Experience has shown that cementatious material is not significantly degraded by radiation exposure of less than $10 \mathrm{E}+9$ rads. Consequently, cement-stabilized waste forms need not be tested unless

a. the waste forms contain ion-exchange resins or other organic media or

b. the expected cumulative waste form dose exceeds $10 \mathrm{E}+9$ rads. 
In these cases, irradiation testing is warranted at the expected exposure rate or $10 \mathrm{E}+8$ rads, whichever is greater, on a minimum of three waste forms for each waste stream formulation being qualified.

Following the irradiation testing, the specimens should be examined visually and should be free of any evidence of significant cracking, spalling or bulk disintegration. Visible evidence of significant degradation would be indicative of a failure of the test. Because it is not possible to provide a priori assessment of the significance of the visible defects, no definition of significant degradation is provided; assessment of the significance of defects is left up to the tester. Photographic records of the defects should be kept. If no significant defects are visible, the specimen should be compression strength tested.

4. Biodegradation Resistance: Since culture growth usually requires a source of carbon, which is not normally present in cement stabilized wastes, biodegradation qualification is not required unless waste forms contain carbonaceous materials. For wastes with carbonaceous materials, there should be no visible culture growth as a result of ASTM G21 and G22 testing. A minimum of three specimens for each carbon waste stream must be tested. The test specimens should also be free from any evidence of significant cracking, spalling, or bulk disintegration. Following the test, specimens without significant visible defects should be compression strength tested.

5. Leach Testing: The 90-day leach test period specified in ANS 16.1 and called out in the regulations is based on the concern that, over time, there could be a change in the leach mechanism that may alter the leach rate. Thus the 90 days allows for that change in rate to be observed. However, any leaching that involves mechanisms such as erosion, dissolution, or corrosion would most likely be readily observed visually during the 90 -day immersion test. Also, experience has shown that there is usually little difference between the observed leach rates of 5- and 90-day leach tests. Consequently, a 5-day leach test is sufficient.

If it can be shown that a chosen leachate is the most aggressive one through a 24-h leach testing comparison of candidate leachates, single leachate testing is appropriate.

6. Immersion Testing: Immersion testing should be performed in either deionized water or synthesized seawater. The immersion liquid should be the most aggressive leachate found in the short-term 24-h leachate testing described previously. At least three specimens, cured for a minimum of 28 days, per waste stream should be tested. Following the immersion testing, the specimens should be examined visually and should be free of any evidence of significant cracking, spalling, or bulk disintegration. Visible evidence of significant degradation would be indicative of a failure of the test. Because it is not possible to provide a priori assessment of the significance of the visible defects, no definition of significant degradation is provided-assessment of the significance of defects is left up to the tester. Photographic records of the defects should be kept. If no significant defects are visible, the specimen should be compression strength tested. Postimmersion strength should be at least $75 \%$ of the preimmersion value and should have a mean no less than 500 psi. If postimmersion compressive strength is less than $75 \%$ of the preimmersion value but with a mean greater than 500 psi, the immersion testing interval should be extended to 180 days with periodic compression strength testing to verify that the strength does not continue to decline. The strength should be observed to level off at a mean above 500 psi. 
For specimens with known complex relationships between cure time and immersion resistance (such as waste forms containing resin beads, chelates, and sludges), additional immersion testing should be performed on specimens that have been cured, in sealed containers, for a minimum of 180 days. The immersion period should be a minimum of 7 days, followed by a drying period of 7 days at $20^{\circ} \mathrm{C}$. After these complex cure-time specimens have dried, they should meet the above-mentioned postimmersion visual and strength test criteria.

7. Free-Standing Liquids: Since cement is an alkaline material, any acidic free-standing liquid is indicative of improper waste preparation. No more than $0.5 \%$ of the volume of cemented waste forms may be free-standing liquid, for which the $\mathrm{pH}$ must be 9 or greater.

8. Mixing/Preparation: Past experience has shown that the method employed in mixing the grout can have a dramatic impact on the resultant properties of the waste form. In preparing laboratory-scale specimens for waste form qualification, it must be shown that the type of equipment used, the mixing time, the speed of the mixer, etc., will, in combination, impart the same degree of mixing and homogeneity that will be imparted to the full-scale waste form.

9. Curing: The curing conditions for the laboratory specimens should be the same as those anticipated for the full-scale operations. Of particular concern is the peak curing centerline temperature profile difference between the laboratory specimen and the full-scale monolith. An acceptable method is to cure the specimens in a suitable oven for a period equivalent to the time it takes for the full-scale waste to decrease in temperature to near ambient temperature $\left(-30^{\circ} \mathrm{C}\right)$.

10. Storage: Test specimens should be kept in sealed containers during curing and pretesting storage. This is intended to simulate the environment of a full-scale operation and will also prevent the loss of water, which could affect the performance of the waste.

\section{Statistical Sampling Requirements:}

a. Compressive Strength: There is usually considerable scatter in compressive strength test data. Therefore, a sufficient number of samples should be tested (at least 10 or more for each formulation) to establish a mean and a standard deviation.

b. Leachability Index: ANSI/ANS 16.1 uses the confidence range and correlation as measures of variability in the reported leachability index values. However, neither ASTM C39 nor the leachability standard have established specific precision criteria. Such criteria will be selected and documented in subsequent project reports related to project quality assurance and procedures.

12. Known Problem Wastes: Table 9 presents several wastes that are known to be problematic to cement waste forms. These wastes should be avoided in grout formulations, or specific adjustments should be made to compensate for and mitigate their effects. 
Table 9. Known problematic wastes

\begin{tabular}{ll}
\hline \multicolumn{1}{c}{ Inorganic constituents } & \multicolumn{1}{c}{ Organic constituents } \\
\hline 1. Borates & $\begin{array}{l}\text { 1. Organic acids } \\
\text { a. Formic acid }\end{array}$ \\
2. Phosphates & 2. Chelates \\
& a. Oxalic acid \\
& b. Citric acid (citrates) \\
& c. Picolinic acid (picolinates) \\
d. EDTA (and its salts) & e. NTA (and its salts) \\
3. Lead salts & 3. Decon solutions \\
4. Zinc salts & 4. Soaps and detergents \\
5. Ammonia and ammonium salts & 5. Oily wastes \\
& a. Benzene \\
& b. Toluene \\
6. Ferric salts & c. Hexane \\
7. Oxidizing agents & 6. Acetone \\
a. Permanganates & 7. Methyl ethyl ketone \\
b. Chromates & 8. Trichloroethane \\
9. Nitrates & 9. Trichlorotriflouroethane \\
10. Sodium hypochlorite & 10. Xylene \\
& 11. Dichlorobenzene
\end{tabular}

${ }^{a}$ EDTA $=$ ethylenediaminetetraacetic acid; NTA $=$ nitrilotriacetic acid.

\subsection{Summary of NRC Waste Form Requirements}

Class A wastes are only required to meet the first set of general criteria discussed in Sect. 5.2.1 and are exempt from the stability testing criteria unless they are disposed of without being segregated from Class B and C wastes. Stability requirements apply to Class B and $\mathrm{C}$ wastes. Table 10 correlates the stability requirement categories with the applicable NRC-recommended test procedure. Substitute test procedure(s) may be used, provided their applicability and validity can be proven.

\subsection{IMPACT ON PHASE I WASTE FORM PERFORMANCE CRITERIA}

NRC performance criteria are significantly different from those of the EPA. While the EPA relies heavily on the TCLP as the major performance criterion for nonwastewaters, NRC relies more heavily on tests related to maintaining the waste form's structural integrity. In addition, the NRC test for free liquids (ANS 55.1) is also different from that used by the EPA [Paint Filter Test (SW846, Method 9095)]. Experience has shown that the ANS 55.1 test is more conservative than the paint filter test. ANS 55.1 will therefore become a performance criterion for this project. 
Table 10. Stability criterion vs test procedures

\begin{tabular}{ll}
\hline \multicolumn{1}{c}{ Stability criterion } & \multicolumn{1}{c}{ Test procedure (reference) } \\
\hline Compressive strength & ASTM C39 or D1074 (6 or 7) \\
Biodegradation & ASTMs G21, G22, and Bartha \\
& Persistence Test $(9,10$, and 11) \\
Leachability & ANS 16.1 (12) \\
Thermal degradation & ASTM B553 (8) \\
Free-standing liquid & ANS 55.1 (5) \\
\hline
\end{tabular}

However, the majority of NRC tests related to structural integrity will not be performed during the Phase I treatability studies. There are three reasons for this decision:

1. The majority of structural integrity tests are time consuming and costly. Since it is not certain that NRC criteria will be applied to the final waste form, the expenditures in cost and time are not justified in the Phase I studies.

2. Unlike the applicable EPA test methods, the test methods are recommended by the NRC and are not codified in the regulations.

3. Even in the case where NRC regulations are applicable, the majority of the tests can be performed as certification tests rather than proof-of-principle. Certification tests are more appropriate for the Phase II studies, as described in Sect. 1.

The NRC tests should not, however, be completely ignored during the Phase I studies. Accordingly, compressive strength will be measured on the products produced in Phase I. Although compressive strength is not quantitatively related to the structural test values, it has been demonstrated to be qualitatively related. It is therefore appropriate to determine compressive strengths during Phase I studies in order to acquire data to assist prediction of Phase II product performance. 


\section{SUMMARY}

The purpose of this document is to define the product performance criteria to be used in Phase I of the Final Waste Forms Project. In Phase I, treatability studies will be performed to provide "proof-of-principle" data to establish the viability of S/S technologies. This information is required for the March 1995 deliverable. In Phase II, further treatability studies, some at the pilot scale, will be performed to provide sufficient data to allow treatment alternatives identified in Phase I to be fully developed and evaluated, as well as to reduce performance uncertainties for those methods chosen to treat a specific waste. The focus of these Phase II efforts will be to obtain the necessary data to design the process morlule(s) and optimize the waste form formulation's ability to accommodate expected variations in both feed characteristics and process operations. While Phase I will be concentrated primarily on laboratory- or bench-scale studies, Phase II will be rocused on laboratory-scale studies as well as both bench-scale and pilot-scale demonstrations.

Three main factors influence the development and selection of an optimum waste form formulation and hence affect selection of performance criteria. These are regulatory, process-specific, and site-specific waste form standards or requirements. Regulatory requirements are those product performance criteria that are required by law or regulation and are typically site independent and may be process independent. For example, a waste form must meet certain concentration-based or technology-based treatment standards, or combinations thereof, in order to be land disposed. In general, these standards are independent of the process and waste form matrix ingredients employed (note, however, that where the treatment standard requires use of a specified technology, the process would not, therefore, be independent).

Process-specific requirements are those pertaining to process variables/constraints such as acceptable waste form fluid viscosity, ability to control the addition and blending/mixing of the formulation ingredients, temperature control, etc. For a grout formulation the process may place constraints on such properties as viscosity, set time, and gel strength.

Site-specific requirements are those pertaining to the storage, handling, and disposal of the waste form product. For example, the waste form may be placed in 55-gal drums, stacked four high, which may place compressive strength requirements on the product to support the intended load. On the other hand, the product may be accumulated for a period of time awaiting shipment off-site and would thus require resistance to atmospheric temperature variations (freeze/thaw resistance). Note that, in addition to regulatory-driven performance criteria for the chemical components of a final waste form, allowable waste form radiological contaminant concentrations and/or activity would be a site-specific performance requirement, as defined by the performance assessment process for the individual disposal site.

Clearly, the optimum waste form formulation will require consideration of performance criteria constraints from each of the three categories. Phase I will focus only on the regulatory criteria. These criteria may be considered the minimum criteria for an acceptable waste form. In other words, an S/S technology is considered viable only if it meets applicable regulatory criteria. Formulation optimization would be performed only on those selected technologies whose viability has been established through screening tests. Identification of viable 
technologies is the purpose of the treatability studies conducted in Phase I. As stated previously, formulation optimization efforts are pari of the Phase II treatability studies.

The criteria to be used in the Phase I treatability studies were primarily taken from EPA regulations addressed in 40 CFR 260 through 265 and 268 and NRC regulations addressed in $10 \mathrm{CFR}$ 61. Although acceptable performance values are waste stream specific, the test methods to evaluate the performance are generic and are summarized in Table 11. The goal of both agencies is the protection of human health and the environment. However, as shown in Table 11, there are differences in the implementation of this goal. Regardless, Table 11 forms the basis for selection of the performance criteria/test methods to be applied in Phase I treatability studies.

Table 11. Comparison of EPA and NRC waste form evaluation methods

\begin{tabular}{lll}
\hline \multicolumn{1}{c}{ Property/parameter } & \multicolumn{1}{c}{ EPA method } & \multicolumn{1}{c}{ NRC method } \\
\hline Leachability & $\begin{array}{l}\text { SW846, Method 1310 } \\
\text { (TCLP) }\end{array}$ & ANS 16.1 \\
& $\begin{array}{l}\text { SW846, Method 9095 } \\
\text { (Paint Filter Test) }\end{array}$ & ANS 55.1 \\
& NA & ASTM C39 \\
Compressive stength & NA & ASTM G21, G22 \\
Biodegradation & NA & ASTM B553 \\
Thermal degradation & &
\end{tabular}

As discussed in Sect. 5.3, the EPA test methods will be given priority in the Phase I Treatability Studies. As such, the first performance criterion becomes acceptable leachate concentrations as determined by the TCLP (both acceptable concentrations and the constituents of interest are waste specific). Although $\mathrm{S} / \mathrm{S}$ products must be designated as a solid per the Paint Filter Test, internal studies (to Energy Systems) have shown that the ANS 55.1 test is more conservative. In addition, these internal studies have shown that modifications to ANS 55.1 in terms of sample size are acceptable. Consequently, the second performance criterion becomes no drainable water as determined by a modified ANS 55.1 test. As discussed in Sect. 5.3, it is appropriate to determine compressive strengths during Phase I studies. Although NRC recommends test method ASTM C39 or equivalent, ASTM C109 (Ref. 14) has been shown in internal studies to be an acceptable substitute and has the added benefit of a smaller sample size, which, in turn, requires less waste material for testing. Consequently, compressive strength will be determined during Phase I studies but will not be assigned a minimum acceptable value.

Throughout Sect. 3 of the text, waste categories and their residues for which stabilization is the specified BDAT are highlighted. For purposes of the Final Waste Forms Project, when stabilization is the specified treatment method, then that waste/waste residue becomes a priority candidate for Phase I treatability studies.

In addition, a $\mathrm{kr} j$ assumption guiding this project is that all applicable treatment standards for organic species subject to LDR and TSCA treatment standards are met by 
pretreatment prior to $S / S$. However, $S / S$ is not precluded as a treatment option for wastes/waste residues for which $S / S$ is not the specified BDAT or for wastes contaminated with multiple waste codes, including organics. Indeed, the EPA has established a precedent for use of reduction in TCLP levels instead of CCW levels "when evaluating waste in which organics are not a principal constituent that have been treated through an immobilization (i.e., $S / S$, in the context of this report) process."15 In addition, in a recent draft engineering bulletin $^{16}$ the EPA has stated that:

The Superfund Policy on use of immobilization is as follows: immobilization is generally appropriate as a treatment alternative only for material containing inorganics, semi-volatile and/or non-volatile organics. Based on present information, the Agency does not believe that immobilization is an appropriate treatment alternative for volatile organics. Selection of immobilization of semi-volatile and non-volatile organics generally requires the performance of a site-specific treatability study or non-site-specific treatability study data generated on waste which is very similar (in terms of type of contaminant, concentration, and waste matrix) to that to be treated and that demonstrates through Total Waste Analyses (TWA), a significant reduction (e.g., a 90 to 99 percent reduction) in the concentration of chemical constituents of concern. The 90 to 99 percent reduction in contaminant concentration is a general guidance and may be varied within a reasonable range considering the effectiveness of the technology and the cleanup goals for the site. Although this policy represents EPA's strong belief that TWA should be used to demonstrate effectiveness of immobilization, other leachability tests may also be appropriate in addition to TWA to evaluate the protectiveness under a specific management scenario.

In addition, the reader should also note that, as a regulatory-based document, this report represents a "snapshot in time" (current as of December 1,1993) and is subject to change. For example, on September 25, 1992, the U.S. Court of Appeals for the District of Columbia Circuit ruled on the various petitions for review filed against the Third rule [Chemical Waste Management, Inc., et al. v. EPA, 976 F. $2 d 2$ (58 FR 29861)]. On May 24, 1993, as part of its response to the September 25 decision, the EPA stated, "The Agency plans to address issues which have been remanded by the court in future rulemaking" (58 FR 29865). Clearly, additional rulemakings that may impact the discussions related to performance criteria in this report are forthcoming. 


\section{REFERENCES}

1. Federal Facility Compliance Agreement for Storage of Radioactive Mixed Waste Subject to Land Disposal Restrictions for the Oak Ridge Reservation in Oak Ridge, Tennessee, Docket 92-02 FFR, USEPA Region IV/DOE-Oak Ridge, June 12, 1992.

2. U.S. Department of Energy Strategic Plan for the Treatment of Appendix B Wastes, DOE/OR-1083, Rev. 0, February 12, 1993.

3. Title 40, Code of Federal Regulations, Subpart D, 268.42, Table 1.

4. Nuclear Regulatory Commission, Waste Form Technical Paper, Revision 1, January 24, 1991.

5. ANS 55.1, "American National Standard for Solidified Radioactive Waste Processing for Light Water Cooled Reactor Plants," American Nuclear Society, 1979.

6. ASTM C39, "Compressive Strength of Cylindrical Concrete Specimens," American Society for Testing and Materials, 1979.

7. ASTM D1074, "Compressive Strength of Bituminous Mixtures," American Society for Testing and Materials, 1980.

8. ASTM B553, "Thermal Cycling of Electroplated Plastics," American Society for Testing and Materials, 1970.

9. ASTM G21, "Determining Resistance of Synthetic Polymeric Materials to Fungi," American Society for Testing and Materials, 1970.

10. ASTM G22, "Determining Resistance of Plastics to Bacteria," American Society for Testing and Materials, 1976.

11. R. Bartha and D. Pramer, "Features of a Flask and Method for Measuring the Persistence and Biological Effects of Pesticides in Soils," Soil Science 100(1), 68-70 (1965).

12. ANS 16.1, "Measurements of the Leachability of Solidified Low-Level Radioactive Wastes," American Nuclear Society Draft Standard, April 1981.

13. A. J. Mattus, T. M. Gilliam, and L. R. Dole, Review of EPA, DOE, and NRC Regulations on Establishing Solid Waste Performance Criteria, ORNL/TM-9322, Oak Ridge National Laboratory, July 1988.

14. ASTM C109, "Compressive Strength of Hydraulic Cement Mortars (Using 2-in. or 50-mm Cube Specimens)," American Society of Testing and Materials, 1980.

15. U.S. EPA, "Superfund LDR Guide \#6B," Superfund Publication: 9347.3-06BFS, September 1990. 
16. U.S. EPA, "Engineering Bulletin: Solidification/Stabilization of Inorganics and Organics," November 1991. 


\section{ACKNOWLEDGMENTS}

The authors wish to express their gratitude to those who participated in the technical review of this report. Their help contributed greatly to the preparation of this document. 
Appendix A.

TREATMENT STANDARDS FOR LISTED WASTES 
APpendix A. TREATMENT STANDARDS FOR LISTED WASTES (NONWASTEWATER)

\begin{tabular}{|c|c|c|c|c|}
\hline Hazardous waste description & $\begin{array}{l}\text { Constituents of } \\
\text { concern }\end{array}$ & $\begin{array}{c}\text { Total } \\
\text { composition } \\
(\mathrm{mg} / \mathrm{kg})\end{array}$ & $\begin{array}{l}\text { TCLP } \\
(\mathrm{mg} / \mathrm{L})\end{array}$ & $\begin{array}{c}\text { BDAT used to } \\
\text { derive treatment } \\
\text { standards }\end{array}$ \\
\hline \multirow[t]{6}{*}{$\begin{array}{l}\text { F001-Spent halogenated solvents } \\
\text { used in degreasing }\end{array}$} & $\begin{array}{l}\text { Carbon tetrachloride } \\
\text { Methylene chloride }\end{array}$ & $\begin{array}{r}5.6 \\
33.0\end{array}$ & & Incineration \\
\hline & Tetrachloroethylene & 5.6 & & \\
\hline & 1,1,1-Trichloroethane & 5.6 & & \\
\hline & Trichloroethylene & 5.6 & & \\
\hline & $\begin{array}{l}\text { 1,1,2-Trichloro-1,2,2- } \\
\text { trifluoroethane }\end{array}$ & 28.0 & & \\
\hline & $\begin{array}{l}\text { Trichloromonofluoro- } \\
\text { methane }\end{array}$ & 33.0 & & \\
\hline \multirow[t]{9}{*}{ F002-Spent halogenated solvents } & Chlorobenzene & 5.7 & & Incineration \\
\hline & o-Dichlorobenzene & 6.2 & & \\
\hline & Methylene chloride & 33.0 & & \\
\hline & Tetrachloroethylene & 5.6 & & \\
\hline & 1,1,1-Trichloroethane & 5.6 & & \\
\hline & 1,1,2-Trichloroethane & 7.6 & & \\
\hline & Trichloroethylene & 5.6 & & \\
\hline & $\begin{array}{l}\text { 1,1,2-Trichloro-1,2,2- } \\
\text { trifluoroethane }\end{array}$ & 28.0 & & \\
\hline & $\begin{array}{l}\text { Trichloromonofluoro- } \\
\text { methane }\end{array}$ & 33.0 & & \\
\hline \multirow[t]{2}{*}{$\begin{array}{l}\text { F003-Spent nonhalogenated } \\
\text { solvents }\end{array}$} & $\begin{array}{l}\text { Acetone } \\
\text { n-Butyl alcohol }\end{array}$ & $\begin{array}{r}160.0 \\
2.6\end{array}$ & & Incineration \\
\hline & Cyclohexanone & & 0.75 & \\
\hline
\end{tabular}




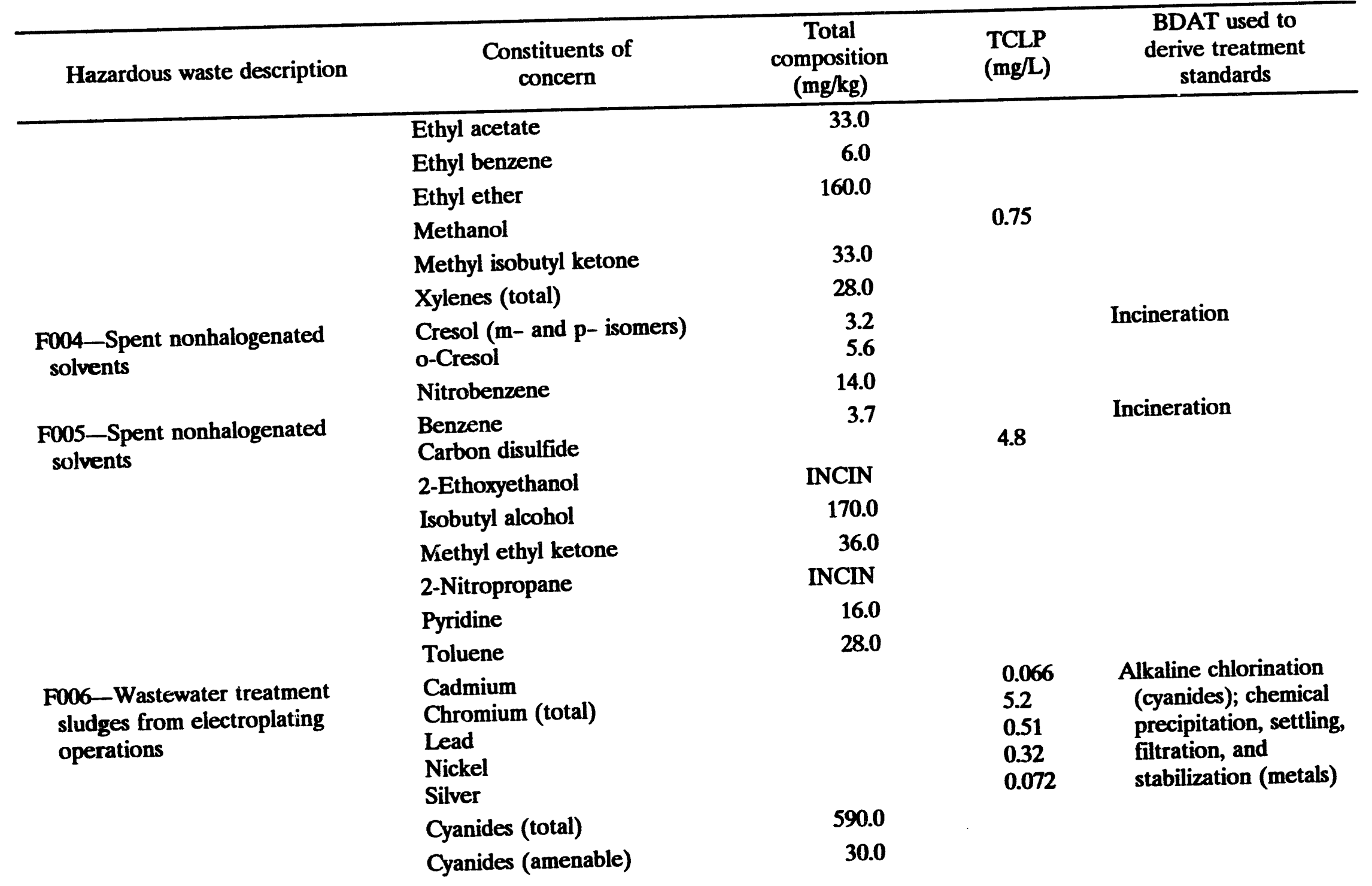




\begin{tabular}{|c|c|c|c|c|}
\hline Hazardous waste description & $\begin{array}{l}\text { Constituents of } \\
\text { concern }\end{array}$ & $\begin{array}{c}\text { Total } \\
\text { composition } \\
(\mathrm{mg} / \mathrm{kg})\end{array}$ & $\begin{array}{c}\text { TCLP } \\
(\mathrm{mg} / \mathrm{L})\end{array}$ & $\begin{array}{c}\text { BDAT used to } \\
\text { derive treatment } \\
\text { standards }\end{array}$ \\
\hline \multirow[t]{12}{*}{$\begin{array}{l}\text { F006-Alternative standards for } \\
\text { nonwastewaters based on high- } \\
\text { temperature metals recovery }\end{array}$} & $\begin{array}{l}\text { Antimony } \\
\text { Arsenic } \\
\text { Barium }\end{array}$ & & $\begin{array}{l}2.1 \\
0.055 \\
7.6\end{array}$ & $\begin{array}{l}\text { Alternative standards } \\
\text { based on high-tempera- } \\
\text { ture metals recovery }\end{array}$ \\
\hline & Beryllium & & 0.014 & \\
\hline & Cadmium & & 0.19 & \\
\hline & Chromium (total) & & 0.33 & \\
\hline & Lead & & 0.37 & $\cdot$ \\
\hline & Mercury & & 0.009 & \\
\hline & Nickel & & 5.0 & \\
\hline & Selenium & & 0.16 & \\
\hline & Silver & & 0.30 & \\
\hline & Thallium & & 0.078 & \\
\hline & Zinc & & 5.3 & \\
\hline & Cyanides (total) & 1.8 & & \\
\hline \multirow[t]{3}{*}{$\begin{array}{l}\text { F007-Spent cyanide plating bath } \\
\text { solutions from electroplating } \\
\text { operations }\end{array}$} & $\begin{array}{l}\text { Cadmium } \\
\text { Chromium (total) } \\
\text { Cyanides (total) } \\
\text { Cyanides (amendable) } \\
\text { Lead }\end{array}$ & $\begin{array}{r}590.0 \\
30.0\end{array}$ & $\begin{array}{l}0.066 \\
5.2\end{array}$ & $\begin{array}{l}\text { Alkaline chlorination } \\
\text { (cyanides); chemical } \\
\text { precipitation, settling, } \\
\text { filtration, and } \\
\text { stabilization (metals) }\end{array}$ \\
\hline & Nickel & & 0.32 & \\
\hline & Silver & & 0.072 & \\
\hline
\end{tabular}




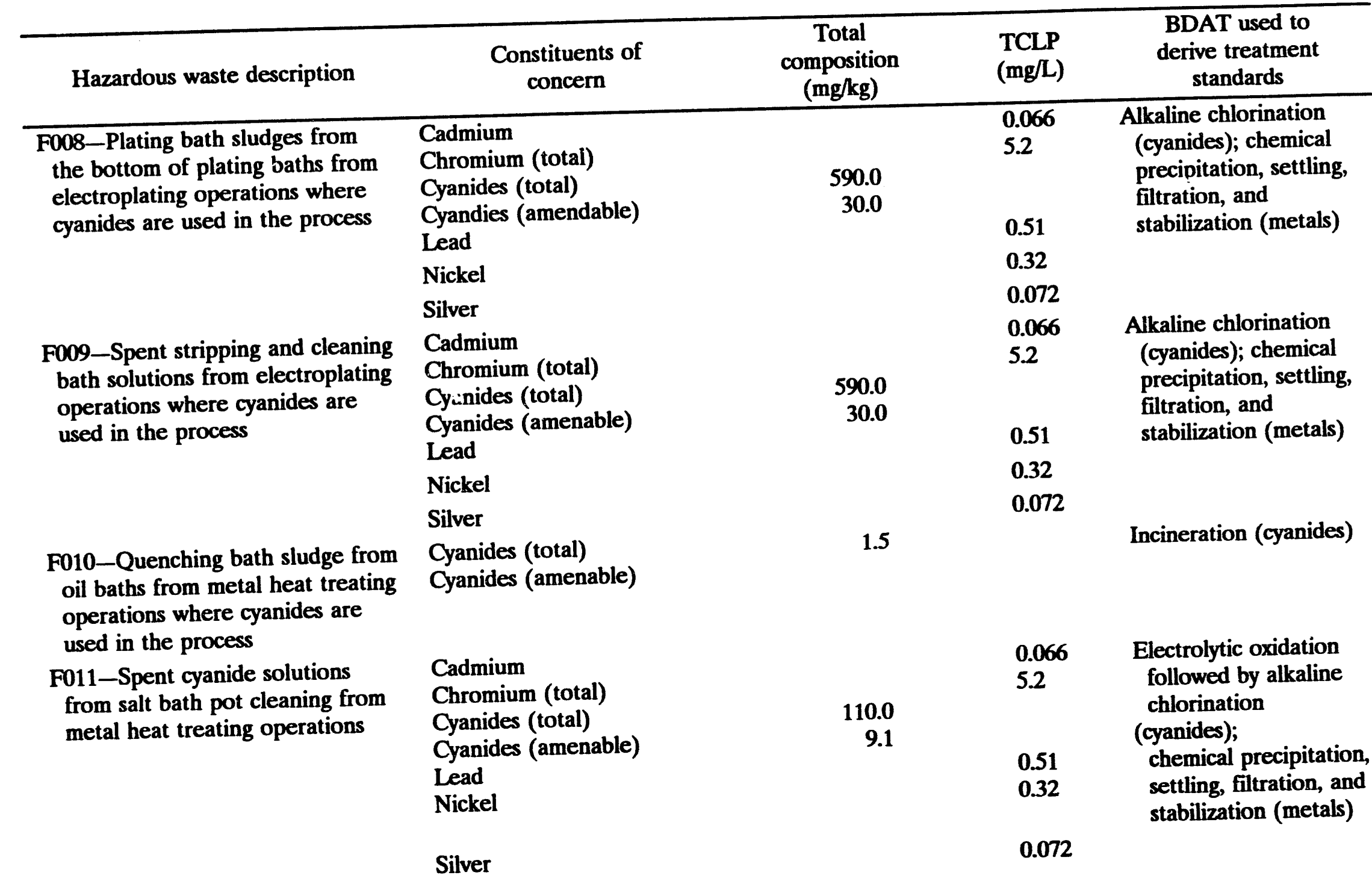




\begin{tabular}{|c|c|c|c|c|}
\hline Hazardous waste description & $\begin{array}{l}\text { Constituents of } \\
\text { concern }\end{array}$ & $\begin{array}{c}\text { Total } \\
\text { composition } \\
(\mathrm{mg} / \mathrm{kg})\end{array}$ & $\begin{array}{l}\text { TCLP } \\
(\mathrm{mg} / \mathrm{L})\end{array}$ & $\begin{array}{l}\text { BDAT used to } \\
\text { derive treatment } \\
\text { standards }\end{array}$ \\
\hline \multirow[t]{2}{*}{$\begin{array}{l}\text { F012-Quenching wastewater } \\
\text { treatment sludges from metal heat } \\
\text { treating operations where } \\
\text { cyanides are used in the process }\end{array}$} & $\begin{array}{l}\text { Cadmium } \\
\text { Chromium (total) } \\
\text { Cyanides (total) } \\
\text { Cyanides (amenable) } \\
\text { Lead } \\
\text { Nickel }\end{array}$ & $\begin{array}{r}110.0 \\
9.1\end{array}$ & $\begin{array}{l}0.066 \\
5.2\end{array}$ & $\begin{array}{l}\text { Electrolytic oxidation } \\
\text { followed by alkaline } \\
\text { chlorination (cyanides); } \\
\text { chemical precipitation, } \\
\text { settling, filtration, and } \\
\text { stabilization (metals) }\end{array}$ \\
\hline & Silver & & 0.072 & \\
\hline $\begin{array}{l}\text { F019-Wastewater treatment } \\
\text { sludges from the chemical } \\
\text { conversion coating of aluminum }\end{array}$ & $\begin{array}{l}\text { Cyanides (total) } \\
\text { Cyanides (amenable) } \\
\text { Chromium (total) }\end{array}$ & $\begin{array}{r}590.0 \\
30.0\end{array}$ & 5.2 & $\begin{array}{l}\text { Alkaline chlorination } \\
\text { (cyanides); stabilization } \\
\text { (chromium) }\end{array}$ \\
\hline \multirow[t]{10}{*}{$\begin{array}{l}\text { F920-F023-Dioxin-containing } \\
\text { wastes }\end{array}$} & $\begin{array}{l}\text { HxCDD-All Hexachlorodi- } \\
\text { benzo-p-dioxins }\end{array}$ & & $<1 \mathrm{ppb}$ & Incineration \\
\hline & $\begin{array}{l}\text { HxCDF-All Hexachlorodi- } \\
\text { benzofurans }\end{array}$ & & $<1 \mathrm{ppb}$ & \\
\hline & $\begin{array}{l}\text { PeCDD-All Pentachlorodi- } \\
\text { benzo-p-dioxins }\end{array}$ & & $<1 \mathrm{ppb}$ & \\
\hline & $\begin{array}{l}\text { PeCDF-All Pentachlorodi- } \\
\text { benzofurans }\end{array}$ & & $<1 \mathrm{ppb}$ & \\
\hline & $\begin{array}{l}\text { TCDD-All Tetrachlorodi- } \\
\text { benzo-p-dioxins }\end{array}$ & & $<1 \mathrm{ppb}$ & \\
\hline & $\begin{array}{l}\text { TCDF-All Tetrachlorodi- } \\
\text { benzofurans }\end{array}$ & & $<1 \mathrm{ppb}$ & \\
\hline & 2,4,5-Trichlorophenol & & $<0.05$ ppm & \\
\hline & 2,4,6-Trichlorophenol & & $<0.05 \mathrm{ppm}$ & \\
\hline & 2,3,4,6-Tetrachlorophenol & & $<0.05$ ppm & \\
\hline & Pentachlorophenol & & $<0.01 \mathrm{ppm}$ & \\
\hline
\end{tabular}




\begin{tabular}{|c|c|c|c|c|}
\hline Hazardous waste description & $\begin{array}{l}\text { Constituents of } \\
\text { concern }\end{array}$ & $\begin{array}{c}\text { Total } \\
\text { composition } \\
(\mathrm{mg} / \mathrm{kg})\end{array}$ & $\begin{array}{l}\mathrm{TCLP} \\
(\mathrm{mg} / \mathrm{L})\end{array}$ & $\begin{array}{l}\text { BDAT used to } \\
\text { derive treatment } \\
\text { standards } \\
\end{array}$ \\
\hline \multirow[t]{9}{*}{$\begin{array}{l}\text { F024-Wastes from the production } \\
\text { of chlorinated aliphatic } \\
\text { hydrocarbons }\end{array}$} & $\begin{array}{l}\text { 2-Chloro-1,3-butadiene } \\
\text { 3-Chloropropene } \\
\text { 1,1-Dichloroethane }\end{array}$ & $\begin{array}{l}\text { INCIN and } 0.28 \\
\text { INCIN and } 0.28 \\
\text { INCIN and } 0.014\end{array}$ & \multirow{9}{*}{$\begin{array}{c}0.073 \\
\text { Reserved } \\
0.088\end{array}$} & $\begin{array}{l}\text { Rotary kiln incineration; } \\
\text { stabilization of } \\
\text { incinerator ash (metals) }\end{array}$ \\
\hline & 1,2-Dicholoroethane & INCIN and 0.014 & & \\
\hline & 1,2-Dichloropropane & INCIN and 0.014 & & \\
\hline & cis-1,3-Dichloropropene & INCIN and 0.014 & & \\
\hline & trans-1,3-Dichloropropene & INCIN and 0.014 & & \\
\hline & Bis(2-ethylhexyl) phthalate & INCIN and 1.8 & & \\
\hline & $\begin{array}{l}\text { Hexachloroethane } \\
\text { Chromium (total) }\end{array}$ & INCIN and 1.8 & & \\
\hline & $\begin{array}{l}\text { Chromium (total) } \\
\text { Lead }\end{array}$ & & & \\
\hline & Nickel & & & \\
\hline \multirow{5}{*}{$\begin{array}{l}\text { F025-Condensed light ends, spent } \\
\text { filters and filter aids, and spent } \\
\text { desiccant wastes from the } \\
\text { production of chlorinated } \\
\text { aliphatics-Light ends } \\
\text { subcategory }\end{array}$} & Chloroform & 6.2 & & Incineration \\
\hline & $\begin{array}{l}\text { 1,2-Dichloroethane } \\
\text { 1,1-Dichloroethylene }\end{array}$ & $\begin{array}{l}6.2 \\
6.2\end{array}$ & & \\
\hline & $\begin{array}{l}\text { 1,1-Dichloroethylene } \\
\text { Methylene chloride }\end{array}$ & $\begin{array}{r}0.2 \\
31.0\end{array}$ & & \\
\hline & $\begin{array}{l}\text { 1,1,2-Trichloroethane } \\
\text { Trichloroethylene }\end{array}$ & $\begin{array}{l}0.2 \\
5.6\end{array}$ & & \\
\hline & Vinyl chloride & 33.0 & & \\
\hline \multirow{5}{*}{$\begin{array}{l}\text { F025-Spent filters/aids and } \\
\text { desiccants subcategory }\end{array}$} & Chloroform & 6.2 & & Incineration \\
\hline & Methylene chloride & 31.0 & & \\
\hline & Carbon tetrachloride & 6.2 & & \\
\hline & 1,1,2-Trichloroethane & 6.2 & & \\
\hline & Trichloroethylene & 5.6 & & \\
\hline
\end{tabular}




\begin{tabular}{|c|c|c|c|c|}
\hline Hazardous waste description & $\begin{array}{l}\text { Constituents of } \\
\text { concern }\end{array}$ & $\begin{array}{c}\text { Total } \\
\text { composition } \\
(\mathrm{mg} / \mathrm{kg})\end{array}$ & $\begin{array}{l}\text { TCLP } \\
(\mathrm{mg} / \mathrm{L})\end{array}$ & $\begin{array}{c}\text { BDAT used to } \\
\text { derive treatment } \\
\text { standards }\end{array}$ \\
\hline \multirow{14}{*}{$\begin{array}{l}\text { F026-F028-Dioxin-containing } \\
\text { wastes }\end{array}$} & Vinyl chloride & 33.0 & & \multirow{14}{*}{ Incineration } \\
\hline & Hexachlorobenzene & 37.0 & & \\
\hline & Hexachlorobutadiene & 28.0 & & \\
\hline & Hexachloroethane & 30.0 & & \\
\hline & $\begin{array}{l}\text { HxCDD-All Hexachloro- } \\
\text { dibenzo-p-dioxins }\end{array}$ & & $<1 \mathrm{ppb}$ & \\
\hline & $\begin{array}{l}\text { HxCDF-All Hexachloro- } \\
\text { dibenzofurans }\end{array}$ & & $<1 \mathrm{ppb}$ & \\
\hline & $\begin{array}{l}\text { PeCDD-All Pentachloro- } \\
\text { dibenzo-p-dioxins }\end{array}$ & & $<1 \mathrm{ppb}$ & \\
\hline & $\begin{array}{l}\text { PeCDF-All Pentachloro- } \\
\text { dibenzofurans }\end{array}$ & & $<1 \mathrm{ppb}$ & \\
\hline & $\begin{array}{l}\text { TCDD-All Tetrachloro- } \\
\text { dibenzo-p-dioxins }\end{array}$ & & $<1 \mathrm{ppb}$ & \\
\hline & $\begin{array}{l}\text { TCDF-All Tetrachloro- } \\
\text { dibenzofurans }\end{array}$ & & $<1 \mathrm{ppb}$ & \\
\hline & 2,4,5-Trichlorophenol & & $<0.05 \mathrm{ppm}$ & \\
\hline & 2,4,6-Trichlorophenol & & $<0.05$ ppm & \\
\hline & 2,3,4,6-Tetrachlorophenol & & $<0.05$ ppm & \\
\hline & Pentachlorophenol & & $<0.01$ ppm & \\
\hline
\end{tabular}




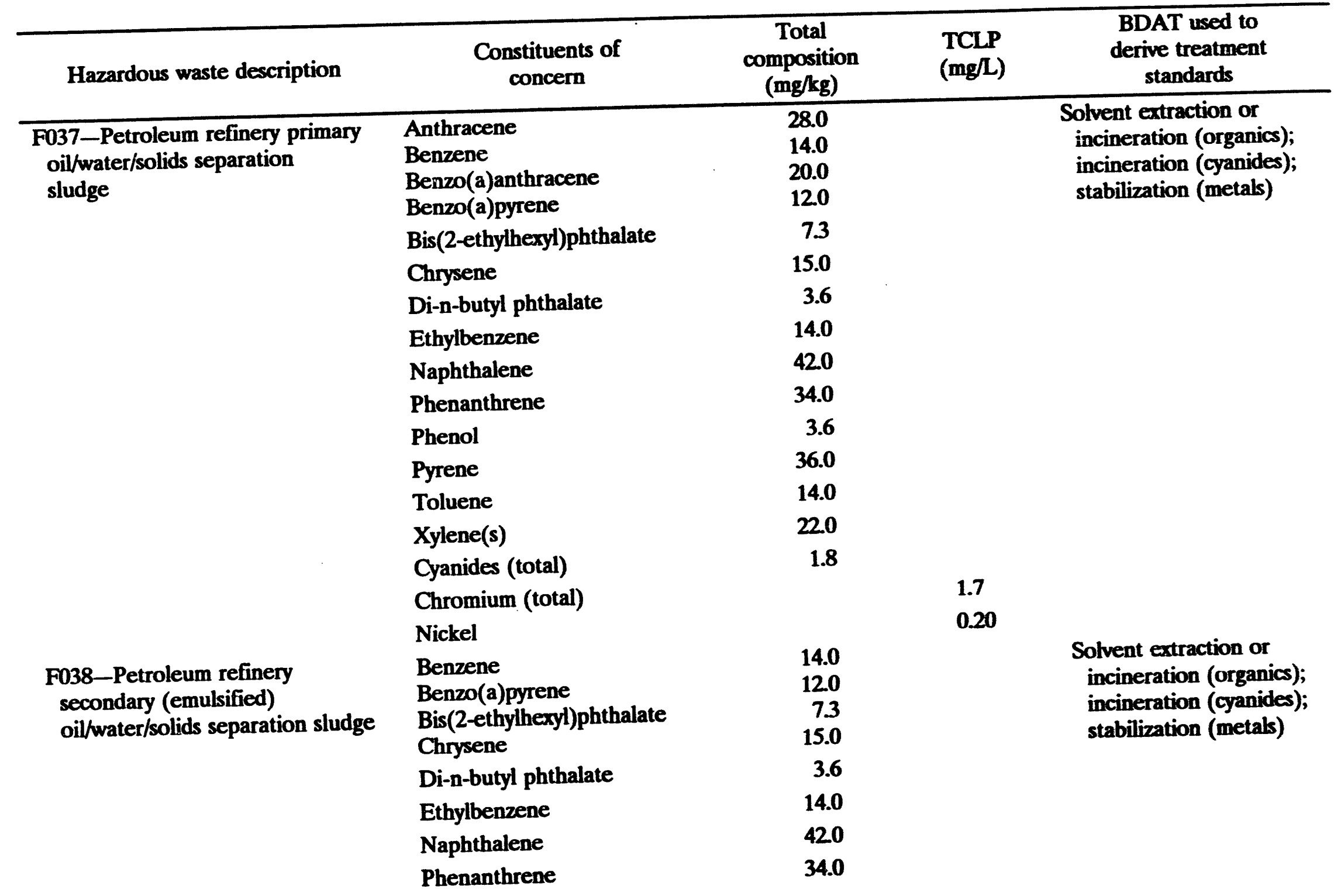




\begin{tabular}{|c|c|c|c|c|}
\hline Hazardous waste description & $\begin{array}{l}\text { Constituents of } \\
\text { concern }\end{array}$ & $\begin{array}{c}\text { Total } \\
\text { composition } \\
(\mathrm{mg} / \mathrm{kg})\end{array}$ & $\begin{array}{l}\text { TCLP } \\
(\mathrm{mg} / \mathrm{L})\end{array}$ & $\begin{array}{l}\text { BDAT used to } \\
\text { derive treatment } \\
\text { standards }\end{array}$ \\
\hline \multirow{22}{*}{$\begin{array}{l}\text { F039 -Multisource leachate } \\
\text { organics (see also F039 } \\
\text { multisource leachate inorganics) }\end{array}$} & Phenol & 3.6 & & \multirow{22}{*}{ Incineration (organics) } \\
\hline & Pyrene & 36.0 & & \\
\hline & Toluene & 14.0 & & \\
\hline & Xylene(s) & 22.0 & & \\
\hline & Cyanides (total) & 1.8 & & \\
\hline & Chromium (total) & & 1.7 & \\
\hline & Nickel & & 0.20 & \\
\hline & $\begin{array}{l}\text { Acetone } \\
\text { Acenaphthalene } \\
\text { Acenaphthene }\end{array}$ & $\begin{array}{r}160.0 \\
3.4 \\
4.0\end{array}$ & & \\
\hline & Acetophenone & 9.7 & & \\
\hline & 2-Acetylaminofluorene & 140.0 & & \\
\hline & Acrylonitrile & 84.0 & & \\
\hline & Aldrin & 0.066 & & \\
\hline & Aniline & 14.0 & & \\
\hline & Anthracene & 4.0 & & \\
\hline & Aroclor 1016 & 0.92 & & \\
\hline & Aroclor 1221 & 0.92 & & \\
\hline & Aroclor 1232 & 0.92 & & \\
\hline & Aroclor 1242 & 0.92 & & \\
\hline & Aroclor 1248 & 0.92 & & \\
\hline & Aroclor 1254 & 1.8 & & \\
\hline & Aroclor 1260 & 1.8 & & \\
\hline & alpha-BHC & 0.066 & & \\
\hline
\end{tabular}




\begin{tabular}{|c|c|c|c|c|}
\hline Hazardous waste description & $\begin{array}{l}\text { Constituents of } \\
\text { concern }\end{array}$ & $\begin{array}{c}\text { Total } \\
\text { composition } \\
(\mathrm{mg} / \mathrm{kg})\end{array}$ & $\begin{array}{l}\text { TCLP } \\
(\mathrm{mg} / \mathrm{L})\end{array}$ & $\begin{array}{l}\text { BDAT used to } \\
\text { derive treatment } \\
\text { standards }\end{array}$ \\
\hline & beta-BHC & 0.066 & & \\
\hline & delta-BHC & 0.066 & & \\
\hline & gamma-BHC & 0.066 & & \\
\hline & Benzene & 36.0 & & \\
\hline & Benz(a)anthracene & 8.2 & & \\
\hline & Benzo(b)fluoranthene & 3.4 & & \\
\hline & Benzo(k)fluoranthene & 3.4 & & \\
\hline & Benzo(g,h,i,)perylene & 1.5 & & \\
\hline & Benzo(a)pyrene & 8.2 & & \\
\hline & Bromodichloromethane & 15.0 & & \\
\hline & $\begin{array}{l}\text { Bromoform } \\
\text { (tribromomethane) }\end{array}$ & 15.0 & & \\
\hline & $\begin{array}{l}\text { Bromomethane (methyl } \\
\text { bromide) }\end{array}$ & 15.0 & & \\
\hline & 4-Bromophenyl phenyl ether & 15.0 & & \\
\hline & n-Butyl alcohol & 26 & & \\
\hline & Butyl benzyl phthalate & 7.9 & & \\
\hline & 2-sec-Butyl-4,6-dinitrophenol & 2.5 & & \\
\hline & Carbon tetrachloride & 5.6 & & \\
\hline & Chlordane & 0.13 & & \\
\hline & p-Chloroaniline & 16.0 & & \\
\hline & Chlorobenzene & 5.7 & & \\
\hline & $\begin{array}{l}\text { Chlorodibromomethane } \\
\text { Chloroethane }\end{array}$ & $\begin{array}{r}15.0 \\
6.0\end{array}$ & & \\
\hline
\end{tabular}




\begin{tabular}{|c|c|c|c|c|}
\hline Hazardous waste description & $\begin{array}{l}\text { Constituents of } \\
\text { concern }\end{array}$ & $\begin{array}{c}\text { Total } \\
\text { composition } \\
\text { (mg/kg) }\end{array}$ & $\underset{(m g / L)}{\text { TCLP }}$ & $\begin{array}{l}\text { BDAT used to } \\
\text { derive treatment } \\
\text { standards }\end{array}$ \\
\hline & bis(2-Chloroethoxy)methane & 7.2 & & \\
\hline & bis(2-Chloroethyl)ether & 7.2 & & \\
\hline & Chloroform & 5.6 & & \\
\hline & bis(2-Chloroisopropyl)ether & 7.2 & & \\
\hline & p-Chloro-m-cresol & 14.0 & & \\
\hline & $\begin{array}{l}\text { Chloromethane (methyl } \\
\text { chloride) }\end{array}$ & 33.0 & & \\
\hline & 2-Chloronaphthalene & 5.6 & & \\
\hline & 2-Chlorophenol & 5.7 & & \\
\hline & 3-Chloropropene & 28.0 & & \\
\hline & Chrysene & 8.2 & & \\
\hline & o-Cresol & 5.6 & & \\
\hline & Cresol (m- and p-isomers) & 3.2 & & \\
\hline & $\begin{array}{l}\text { 1,2-Dibromo-3- } \\
\text { chloropropane }\end{array}$ & 15.0 & & \\
\hline & $\begin{array}{l}\text { 1,2-Dibromoethane (ethylene } \\
\text { dibromide) }\end{array}$ & 15.0 & & \\
\hline & Dibromomethane & 15.0 & & \\
\hline & $\begin{array}{l}\text { 2,4-Dichlorophenoxyacetic } \\
\text { acid }(2,4-D)\end{array}$ & 10.0 & & \\
\hline & $\mathbf{o , p ^ { \prime } - \mathrm { DDD }}$ & 0.087 & & \\
\hline & p,p'-DDD & 0.087 & & \\
\hline & $0, p^{\prime}-D D E$ & 0.087 & & \\
\hline & p,p'-DDE & 0.087 & & \\
\hline
\end{tabular}




\begin{tabular}{|c|c|c|c|c|}
\hline Hazardous waste description & $\begin{array}{l}\text { Constituents of } \\
\text { concern }\end{array}$ & $\begin{array}{c}\text { Total } \\
\text { composition } \\
(\mathrm{mg} / \mathrm{kg})\end{array}$ & $\begin{array}{l}\text { TCLP } \\
(\mathrm{mg} / \mathrm{L})\end{array}$ & $\begin{array}{l}\text { BDAT used to } \\
\text { derive treatment } \\
\text { standards }\end{array}$ \\
\hline & o,p'-DDT & 0.087 & & \\
\hline & p,p'-DDT & 0.087 & & \\
\hline & Dibenz(a,h)anthracene & 8.2 & & \\
\hline & m-Dichlorobenzene & 6.2 & & \\
\hline & o-Dichlorobenzene & 6.2 & & \\
\hline & p-Dichlorobenzene & 6.2 & & \\
\hline & Dichlorodifluoromethane & 7.2 & & \\
\hline & 1,1-Dichloroethane & 7.2 & & \\
\hline & 1,2-Dichloroethane & 7.2 & & \\
\hline & 1,1-Dichloroethylene & 33.0 & & \\
\hline & trans-1,2-Dichloroethylene & 33.0 & & \\
\hline & $\begin{array}{l}\text { 2,4-Dichlorophenol } \\
\text { 2,6-Dichlorophenol }\end{array}$ & 14.0 & & \\
\hline & $\begin{array}{l}\text { 2,6-Dichlorophenol } \\
\text { 1,2-Dichloropropane }\end{array}$ & 14.0 & & \\
\hline & $\begin{array}{l}\text { 1,2-Dichloropropane } \\
\text { cis-1,3-Dichloropropene }\end{array}$ & 18.0 & & \\
\hline & $\begin{array}{l}\text { cis-1,3-Dichloropropene } \\
\text { trans-1,3-Dichloropropene }\end{array}$ & 18.0 & & \\
\hline & $\begin{array}{l}\text { trans-1,3-Dichloropropene } \\
\text { Dieldrin }\end{array}$ & 18.0 & & \\
\hline & $\begin{array}{l}\text { Dieldrin } \\
\text { Diethyl phthalate }\end{array}$ & 0.13 & & \\
\hline & $\begin{array}{l}\text { Diethyl phthalate } \\
\text { 2,4-Dimethyl phenol }\end{array}$ & 28.0 & & \\
\hline & $\begin{array}{l}\text { 2,4-Dimethyl phenol } \\
\text { Dimethyl phthalate }\end{array}$ & 14.0 & & \\
\hline & $\begin{array}{l}\text { Dimethyl phthalate } \\
\text { Di-n-butyl phthalate }\end{array}$ & 28.0 & & \\
\hline & $\begin{array}{l}\text { Di-n-butyl phthalate } \\
\text { 1,4-Dinitrobenzene }\end{array}$ & 28.0 & & \\
\hline & $\begin{array}{l}\text { 1,4-Dinitrobenzene } \\
\text { 4,6-Dinitro-o-cresol }\end{array}$ & 2.3 & & \\
\hline & 4,6-Dinitro-o-cresol & 160.0 & & \\
\hline
\end{tabular}




\begin{tabular}{|c|c|c|c|c|}
\hline Hazardous waste description & $\begin{array}{l}\text { Constituents of } \\
\text { concern }\end{array}$ & $\begin{array}{c}\text { Total } \\
\text { composition } \\
(\mathrm{mg} / \mathrm{kg})\end{array}$ & $\begin{array}{c}\text { TCLP } \\
(\mathrm{mg} / \mathrm{L})\end{array}$ & $\begin{array}{l}\text { BDAT used to } \\
\text { derive treatment } \\
\text { standards }\end{array}$ \\
\hline & 2,4-Dinitrophenol & 160.0 & & \\
\hline & 2,4-Dinitrotoluene & 140.0 & & \\
\hline & 2,6-Dinitrotoluene & 28.0 & & \\
\hline & Di-n-octyl phthalate & 28.0 & & \\
\hline & Di-n-propylnitrosoamine & 14.0 & & \\
\hline & 1,4-Dioxane & 170.0 & & \\
\hline & Disulfoton & 6.2 & & \\
\hline & Endosulfan I & 0.066 & & \\
\hline & Endosulfan II & 0.13 & & \\
\hline & Endosulfan sulfate & 0.13 & & \\
\hline & Endrin & 0.13 & & \\
\hline & Endrin aldehyde & 0.13 & & \\
\hline & Ethyl acetate & 33.0 & & \\
\hline & Ethyl cyanide & 360.0 & & \\
\hline & Ethyl benzene & 6.0 & & \\
\hline & Ethyl ether & 160.0 & & \\
\hline & bis-(2-Ethylhexyl)phthalate & 28.0 & & \\
\hline & Ethyl methacrylate & 160.0 & & \\
\hline & Famphur & 15.0 & & \\
\hline & Fluoranthene & 8.2 & & \\
\hline & Fluorene & 4.0 & & \\
\hline & Fluorotrichloromethane & 33.0 & & \\
\hline & Heptachlor & 0.066 & & \\
\hline
\end{tabular}




\begin{tabular}{|c|c|c|c|c|}
\hline Hazardous waste description & $\begin{array}{l}\text { Constituents of } \\
\text { concern }\end{array}$ & $\begin{array}{c}\text { Total } \\
\text { composition } \\
(\mathrm{mg} / \mathrm{kg})\end{array}$ & $\begin{array}{l}\text { TCLP } \\
(\mathrm{mg} / \mathrm{L})\end{array}$ & $\begin{array}{l}\text { BDAT used to } \\
\text { derive treatment } \\
\text { standards }\end{array}$ \\
\hline & Heptachlor epoxide & 0.066 & & \\
\hline & Hexachlorobenzene & 37.0 & & \\
\hline & Hexachlorobutadiene & 28.0 & & \\
\hline & Hexachlorocyclopentadiene & 3.6 & & \\
\hline & Hexachlorodibenzo-furans & 0.001 & & \\
\hline & Hexachlorodibenzo-p-dioxins & 0.001 & & \\
\hline & Hexachloroethane & 28.0 & & \\
\hline & Hexachloropropene & 28.0 & & \\
\hline & Indeno(1,2,3-c,d)pyrene & 8.2 & & \\
\hline & Iodomethane & 65.0 & & \\
\hline & Isobutanol & 170.0 & & \\
\hline & Isodrin & 0.066 & & \\
\hline & Isosafrole & $\begin{array}{l}2.6 \\
013\end{array}$ & & \\
\hline & $\begin{array}{l}\text { Kepone } \\
\text { Methacrylonitrile }\end{array}$ & $\begin{array}{l}0.13 \\
84.0\end{array}$ & & \\
\hline & $\begin{array}{l}\text { Methacrylonitrile } \\
\text { Methapyrilene }\end{array}$ & 1.5 & & \\
\hline & Methoxychlor & 0.18 & & \\
\hline & 3-Methylcholanthrene & 15.0 & & \\
\hline & $\begin{array}{l}\text { 4,4-Methylene-bis- } \\
\text { (2-chloroaniline) }\end{array}$ & 35.0 & & \\
\hline & Methylene chloride & 33.0 & & \\
\hline & Methyl ethyl ketone & 36.0 & & \\
\hline & Methyl isobutyl ketone & 33.0 & & \\
\hline & Methyl methacrylate & 160.0 & & \\
\hline
\end{tabular}




\begin{tabular}{|c|c|c|c|c|}
\hline Hazardous waste description & $\begin{array}{l}\text { Constituents of } \\
\text { concern }\end{array}$ & $\begin{array}{c}\text { Total } \\
\text { composition } \\
(\mathrm{mg} / \mathrm{kg})\end{array}$ & $\begin{array}{l}\text { TCLP } \\
(\mathrm{mg} / \mathrm{L})\end{array}$ & $\begin{array}{l}\text { BDAT used to } \\
\text { derive treatment } \\
\text { standards }\end{array}$ \\
\hline & Methyl parathion & 4.6 & & \\
\hline & Naphthalene & 3.1 & & \\
\hline & p-Nitroaniline & 28.0 & & \\
\hline & Nitrobenzene & 14.0 & & \\
\hline & 5-Nitro-o-toluidine & 28.0 & & \\
\hline & 4-Nitrophenol & 29.0 & & \\
\hline & N-Nitrosodiethylamine & 28.0 & & \\
\hline & N-Nitroso-di-n-butylamine & 17.0 & & \\
\hline & N-Nitrosomethylethylamine & 2.3 & & \\
\hline & N-Nitrosomorpholine & 2.3 & & \\
\hline & N-Nitrosopiperidine & 35.0 & & \\
\hline & N-Nitrosopyrrolidine & 35.0 & & \\
\hline & Parathion & 4.6 & & \\
\hline & Pentachlorobenzene & 37.0 & & \\
\hline & Pentachlorodibenzo-furans & 0.001 & & \\
\hline & $\begin{array}{l}\text { Pentachlorodibenzo-p- } \\
\text { dioxins }\end{array}$ & & & \\
\hline & Pentachloronitrobenzene & 4.8 & & \\
\hline & Pentachlorophenol & 7.4 & & \\
\hline & Phenacetin & 16.0 & & \\
\hline & Phenanthrene & 3.1 & & \\
\hline & Phenol & 6.2 & & \\
\hline & Phorate & 4.6 & & \\
\hline & Pronamide & 1.5 & & \\
\hline
\end{tabular}




\begin{tabular}{|c|c|c|c|c|}
\hline Hazardous waste description & $\begin{array}{l}\text { Constituents of } \\
\text { concern }\end{array}$ & $\begin{array}{c}\text { Total } \\
\text { composition } \\
(\mathrm{mg} / \mathrm{kg})\end{array}$ & $\begin{array}{l}\text { TCLP } \\
(\mathrm{mg} / \mathrm{L})\end{array}$ & $\begin{array}{l}\text { BDAT used to } \\
\text { derive treatment } \\
\text { standards }\end{array}$ \\
\hline & Pyrene & 8.2 & & \\
\hline & Pyridine & 16.0 & & \\
\hline & Safrole & 22.0 & & \\
\hline & Silvex $(2,4,5-T P)$ & 7.9 & & \\
\hline & $2,4,5-\mathrm{T}$ & 7.9 & & \\
\hline & 1,2,4,5-Tetrachlorobenzene & 19.0 & & \\
\hline & Tetrachlorodibenzo-furans & 0.001 & & \\
\hline & Tetrachlorodibenzo-p-dioxins & 0.001 & & \\
\hline & 1,1,1,2-Tetrachloroethane & 42.0 & & \\
\hline & 1,1,2,2-Tetrachloroethane & 42.0 & & \\
\hline & Tetrachloroethylene & 5.6 & & \\
\hline & 2,3,4,6-Tetrachlorophenol & 37.0 & & \\
\hline & Toluene & 28.0 & & \\
\hline & Toxaphene & 1.3 & & \\
\hline & 1,2,4-Trichlorobenzene & 19.0 & & \\
\hline & 1,1,1-Trichloroethane & $\begin{array}{l}5.6 \\
5.6\end{array}$ & & \\
\hline & $\begin{array}{l}\text { 1,1,2-Trichloroethane } \\
\text { Trichloroethylene }\end{array}$ & 5.6 & & \\
\hline & 2,4,5-Trichlorophenol & 37.0 & & \\
\hline & 2,4,6-Trichlorophenol & 37.0 & & \\
\hline & 1,2,3-Trichloropropane & 28.0 & & \\
\hline & $\begin{array}{l}\text { 1,1,2-Trichloro-1,2,2-tri- } \\
\text { fluoroethane }\end{array}$ & 28.0 & & \\
\hline & Vinyl chloride & 33.0 & & \\
\hline
\end{tabular}




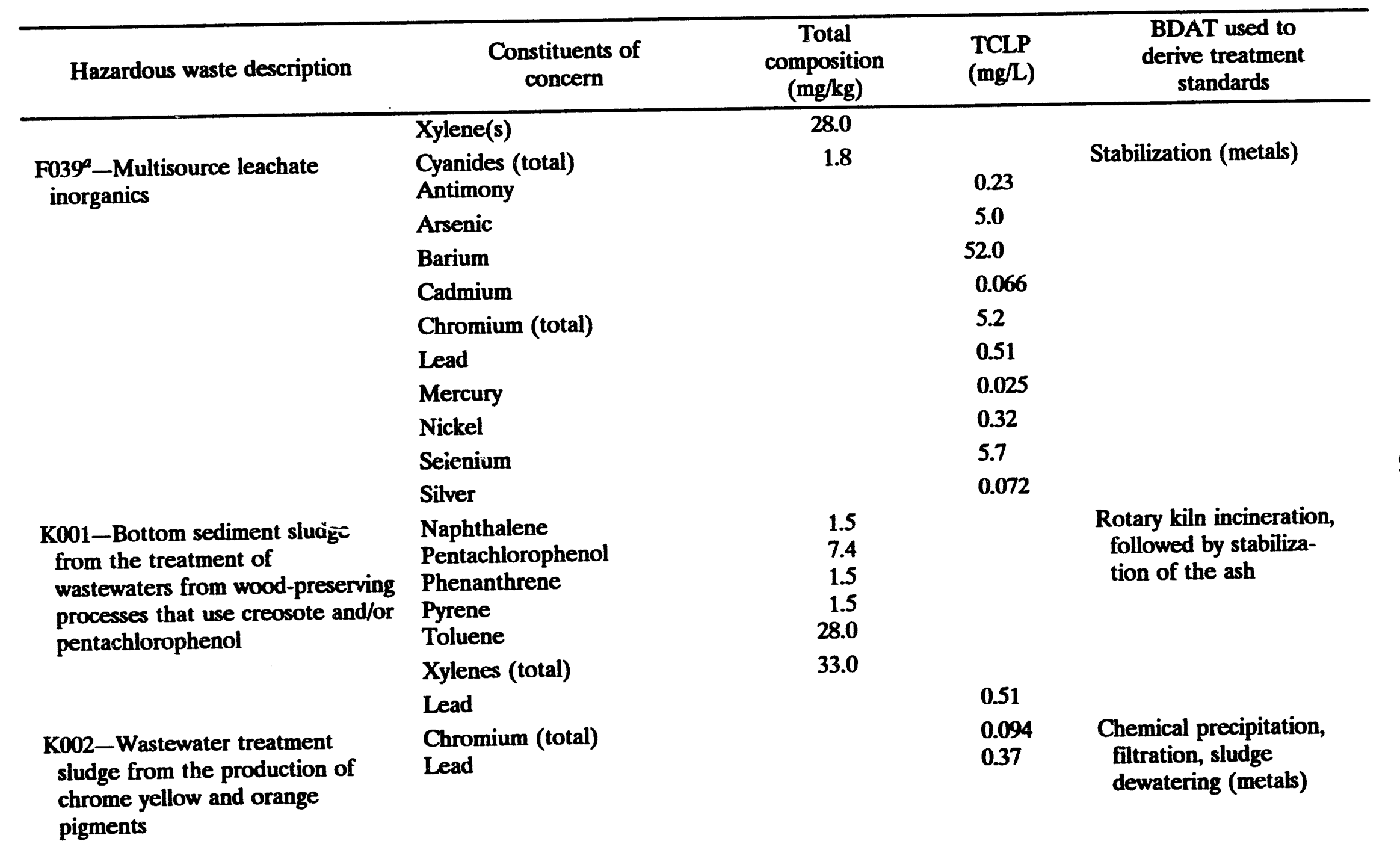




\begin{tabular}{|c|c|c|c|c|}
\hline Hazardous waste description & $\begin{array}{l}\text { Constituents of } \\
\text { concern }\end{array}$ & $\begin{array}{c}\text { Total } \\
\text { composition } \\
(\mathrm{mg} / \mathrm{kg})\end{array}$ & $\begin{array}{l}\text { TCLP } \\
(\mathrm{mg} / \mathrm{L})\end{array}$ & $\begin{array}{l}\text { BDAT used to } \\
\text { derive treatment } \\
\text { standards }\end{array}$ \\
\hline $\begin{array}{l}\text { K003-Wastewater treatment } \\
\text { sludge froni the production of } \\
\text { molybdate orange pigments }\end{array}$ & $\begin{array}{l}\text { Chromium (total) } \\
\text { Lead }\end{array}$ & & $\begin{array}{l}0.094 \\
0.37\end{array}$ & $\begin{array}{l}\text { Chemical precipitation, } \\
\text { filtration, sludge } \\
\text { dewatering (metals) }\end{array}$ \\
\hline $\begin{array}{l}\text { K004-Wastewater treatment } \\
\text { sludge from the production of } \\
\text { zinc yellow pigments }\end{array}$ & $\begin{array}{l}\text { Chromium (total) } \\
\text { Lead }\end{array}$ & & $\begin{array}{l}0.094 \\
0.37\end{array}$ & $\begin{array}{l}\text { Chemical precipitation, } \\
\text { filtration, sludge } \\
\text { dewatering (metals) }\end{array}$ \\
\hline $\begin{array}{l}\text { K005-Wastewater treatment } \\
\text { sludge from the production of } \\
\text { chrome green pigments }\end{array}$ & $\begin{array}{l}\text { Chromium (total) } \\
\text { Lead } \\
\text { Cyanides (total) }\end{array}$ & Reserved & $\begin{array}{l}0.094 \\
0.37\end{array}$ & $\begin{array}{l}\text { Chemical precipitation, } \\
\text { filtration, sludge } \\
\text { dewatering (metals) }\end{array}$ \\
\hline $\begin{array}{l}\text { K006-Wastewater treatment } \\
\text { sludge from the production of } \\
\text { chrome oxide green pigments } \\
\text {-Anhydrous } \\
\text {-Hydrated }\end{array}$ & $\begin{array}{l}\text { Chromium (total) } \\
\text { Lead } \\
\text { Chromium (total) }\end{array}$ & & $\begin{array}{l}0.094 \\
0.37 \\
5.2\end{array}$ & $\begin{array}{l}\text { Chemical precipitation, } \\
\text { filtration, stabilization } \\
\text { (chromium) }\end{array}$ \\
\hline $\begin{array}{l}\text { K007-Wastewater treatment } \\
\text { sludge from the production of } \\
\text { iron } \\
\text { blue pigments }\end{array}$ & $\begin{array}{l}\text { Chromium (total) } \\
\text { Lead } \\
\text { Cyanides (total) }\end{array}$ & Reserved & $\begin{array}{l}0.094 \\
0.37\end{array}$ & $\begin{array}{l}\text { Chemical precipitation, } \\
\text { filtration, sludge } \\
\text { dewatering (metals) }\end{array}$ \\
\hline $\begin{array}{l}\text { K008-Oven residue from the } \\
\text { production of chrome oxide green } \\
\text { pigments }\end{array}$ & $\begin{array}{l}\text { Chromium (total) } \\
\text { Lead }\end{array}$ & & $\begin{array}{l}0.094 \\
0.37\end{array}$ & $\begin{array}{l}\text { Chemical precipitation, } \\
\text { filtration, sludge } \\
\text { dewatering (metals) }\end{array}$ \\
\hline $\begin{array}{l}\text { K009-Distillation bottoms from } \\
\text { the production of acetaldehyde } \\
\text { from ethylene }\end{array}$ & Chloroform & 6.0 & & Rotary kiln incineration \\
\hline $\begin{array}{l}\text { K010-Distillation side cuts from } \\
\text { the production of acetaldehyde } \\
\text { from ethylene }\end{array}$ & Chloroform & 6.0 & & Rotary kiln incineration \\
\hline
\end{tabular}




\begin{tabular}{|c|c|c|c|c|}
\hline Hazardous waste description & $\begin{array}{l}\text { Constituents of } \\
\text { concern }\end{array}$ & $\begin{array}{c}\text { Total } \\
\text { composition } \\
(\mathrm{mg} / \mathrm{kg})\end{array}$ & $\begin{array}{l}\text { TCLP } \\
(\mathrm{mg} / \mathrm{L})\end{array}$ & $\begin{array}{l}\text { BDAT used to } \\
\text { derive treatment } \\
\text { standards }\end{array}$ \\
\hline \multirow{4}{*}{$\begin{array}{l}\text { K011-Bottom stream from the } \\
\text { wastewater stripper in the } \\
\text { production of acrylonitrile }\end{array}$} & Acetonitrile & 1.8 & & \multirow[t]{5}{*}{ Incineration } \\
\hline & Acrylonitrile & 1.4 & & \\
\hline & $\begin{array}{l}\text { Acrylamide } \\
\text { Benzene }\end{array}$ & 23.0 & & \\
\hline & $\begin{array}{l}\text { Benzene } \\
\text { Cyanides (total) }\end{array}$ & 0.03 & & \\
\hline \multirow{5}{*}{$\begin{array}{l}\text { K013-Bottom stream from the } \\
\text { acetonitrile column in the } \\
\text { production of acrylonitrile }\end{array}$} & $\begin{array}{l}\text { Cyanides (total) } \\
\text { Acetonitrile }\end{array}$ & 57.0 & & \\
\hline & $\begin{array}{l}\text { Acetonitrile } \\
\text { Acrylonitrile }\end{array}$ & $\begin{array}{l}1.8 \\
1.4\end{array}$ & & \multirow{4}{*}{ Incineration } \\
\hline & Acrylamide & 23.0 & & \\
\hline & Benzene & 0.03 & & \\
\hline & Cyanides (total) & 57.0 & & \\
\hline \multirow{4}{*}{$\begin{array}{l}\text { K014-Bottoms from the } \\
\text { acetonitrile purification column } \\
\text { in the production of acrylonitrile }\end{array}$} & Acetonitrile & 1.8 & & \multirow[t]{4}{*}{ Incineration } \\
\hline & $\begin{array}{l}\text { Acrylonitrile } \\
\text { Acrylamide }\end{array}$ & $\begin{array}{r}1.4 \\
23.0\end{array}$ & & \\
\hline & Benzene & 0.03 & & \\
\hline & Cyanides (total) & 57.0 & & \\
\hline \multirow{7}{*}{$\begin{array}{l}\text { K015-Still bottoms from the } \\
\text { distillation of benzyl chloride }\end{array}$} & Anthracene & 3.4 & & \multirow{7}{*}{$\begin{array}{l}\text { Incineration (organics), } \\
\text { stabilization (metals) }\end{array}$} \\
\hline & Benzal chloride & 6.2 & & \\
\hline & $\begin{array}{l}\text { Sum of Benzo(b)- } \\
\text { fluoranthene and } \\
\text { Benzo(k)fluoranthene }\end{array}$ & 3.4 & & \\
\hline & Phenanthrene & 3.4 & & \\
\hline & Toluene & 6.0 & & \\
\hline & Chromium (total) & & 1.7 & \\
\hline & Nickel & & 0.2 & \\
\hline
\end{tabular}




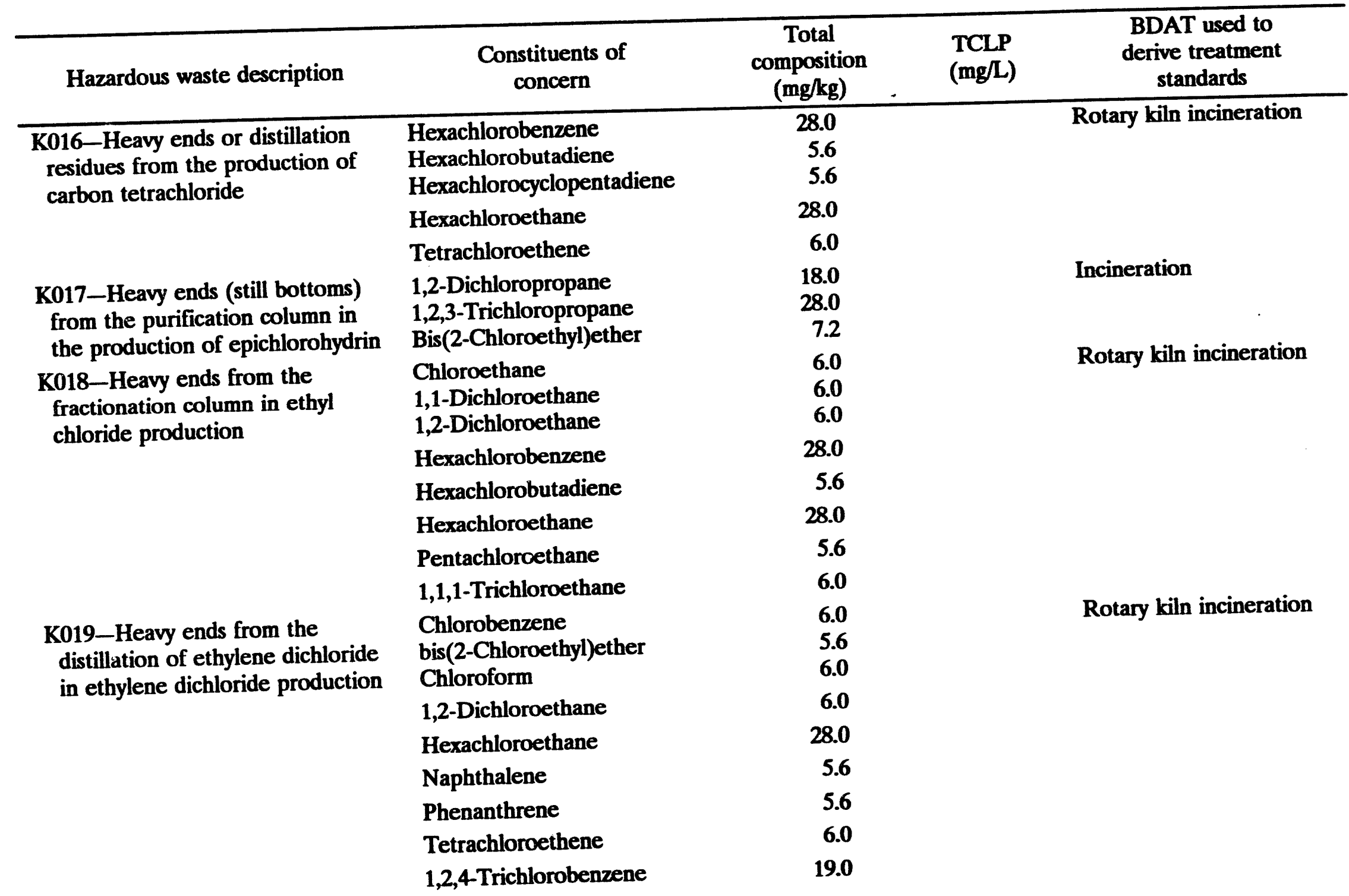




\begin{tabular}{|c|c|c|c|c|}
\hline Hazardous waste description & $\begin{array}{l}\text { Constituents of } \\
\text { concern }\end{array}$ & $\begin{array}{c}\text { Total } \\
\text { composition } \\
(\mathrm{mg} / \mathrm{kg})\end{array}$ & $\begin{array}{l}\text { TCLP } \\
(\mathrm{mg} / \mathrm{L})\end{array}$ & $\begin{array}{l}\text { BDAT used to } \\
\text { derive treatment } \\
\text { standards }\end{array}$ \\
\hline & 1,1,1-Trichloroethane & 6.0 & & \\
\hline $\begin{array}{l}\text { K020-Heavy ends from the } \\
\text { distillation of vinyl chloride in } \\
\text { vinyl chloride monomer } \\
\text { production }\end{array}$ & $\begin{array}{l}\text { 1,2-Dichloroethane } \\
\text { 1,1,2,2-Tetrachloroethane } \\
\text { Tetrachloroethene }\end{array}$ & $\begin{array}{l}6.0 \\
5.6 \\
6.0\end{array}$ & & Rotary kiln incineration \\
\hline $\begin{array}{l}\text { K021-Aqueous spent antimony } \\
\text { catalyst waste from fluoromethane } \\
\text { production }\end{array}$ & $\begin{array}{l}\text { Chloroform } \\
\text { Carbon tetrachloride } \\
\text { Antimony }\end{array}$ & $\begin{array}{l}6.2 \\
6.2\end{array}$ & 0.23 & $\begin{array}{l}\text { Incineration (organics) } \\
\text { and stabilization } \\
\text { (inorganics) }\end{array}$ \\
\hline \multirow[t]{4}{*}{$\begin{array}{l}\text { K022-Distillation bottom tars } \\
\text { from the production of } \\
\text { phenol/acetone from cumene }\end{array}$} & $\begin{array}{l}\text { Acetophenone } \\
\text { Phenol } \\
\text { Toluene }\end{array}$ & $\begin{array}{l}19.0 \\
12.0 \\
0.034\end{array}$ & & $\begin{array}{l}\text { Incineration or fuel } \\
\text { substitution, } \\
\text { solidification of ash }\end{array}$ \\
\hline & $\begin{array}{l}\text { Sum of diphenylamine and } \\
\text { diphenylnitrosamine }\end{array}$ & 13.0 & & \\
\hline & Chromium (total) & & 5.2 & \\
\hline & Nickel & & 0.32 & \\
\hline $\begin{array}{l}\text { K023-Distillation light ends from } \\
\text { the production of phthalic } \\
\text { anhydride from naphthalene }\end{array}$ & $\begin{array}{l}\text { Phthalic anhydride } \\
\text { (measured as phthalic acid) }\end{array}$ & 28.0 & & Rotary kiln incineration \\
\hline $\begin{array}{l}\text { K024-Distillation bottoms from } \\
\text { the production of phthalic } \\
\text { anhydride from naphthalene }\end{array}$ & $\begin{array}{l}\text { Phthalic anhydride } \\
\text { (measured as phthalic acid) }\end{array}$ & 28.0 & & $\begin{array}{l}\text { Incineration or fuel } \\
\text { substitution, } \\
\text { solidification of ash }\end{array}$ \\
\hline $\begin{array}{l}\text { K025-Distillation bottoms from } \\
\text { th:; production of nitrobenzene by } \\
\text { the nitration of benzene }\end{array}$ & & INCIN & & \\
\hline $\begin{array}{l}\text { K026-Stripping still tails from the } \\
\text { production of methyl ethyl } \\
\text { pyridines }\end{array}$ & & INCIN & & \\
\hline
\end{tabular}




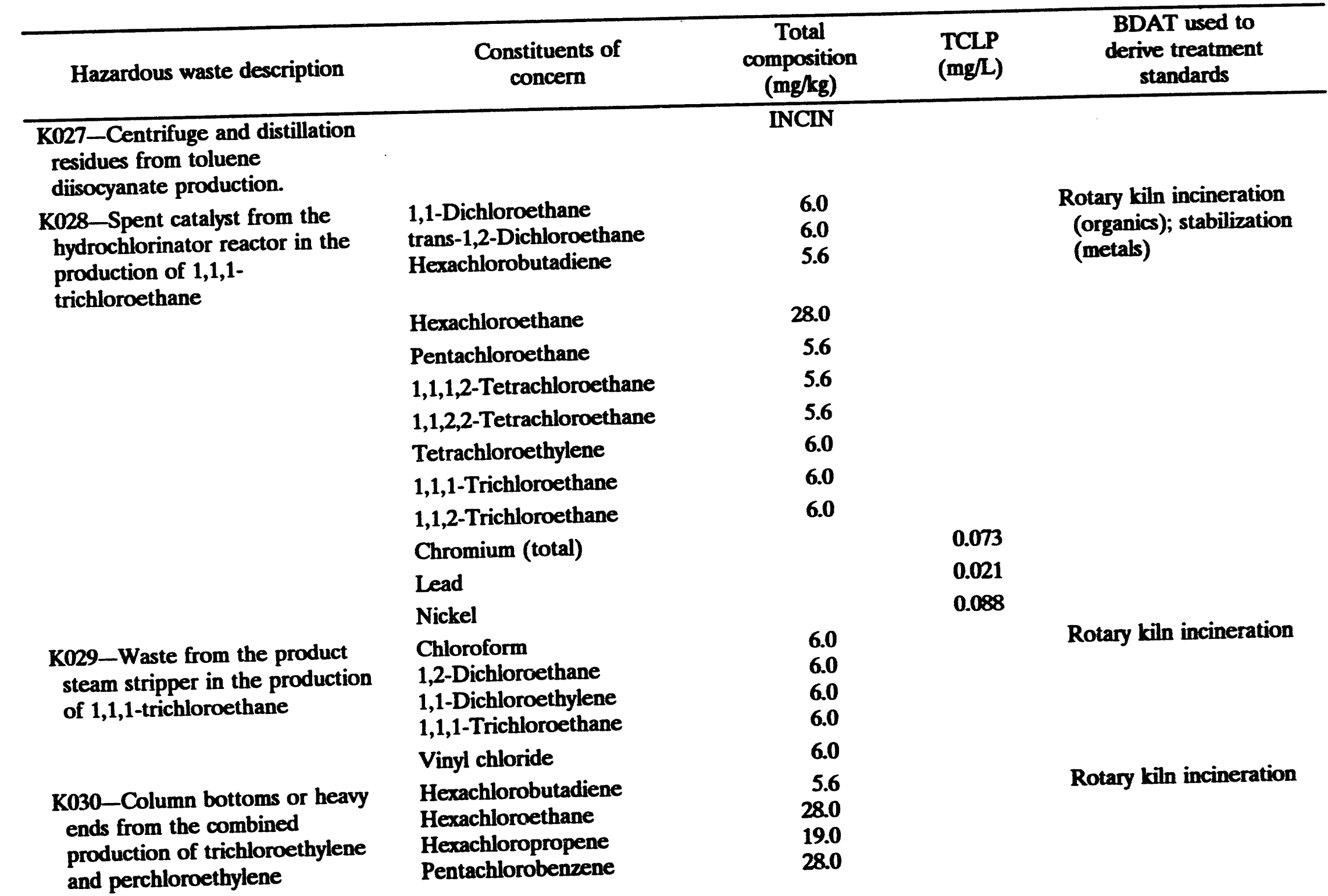




\begin{tabular}{|c|c|c|c|c|}
\hline Hazardous waste description & $\begin{array}{l}\text { Constituents of } \\
\text { concern }\end{array}$ & $\begin{array}{c}\text { Total } \\
\text { composition } \\
(\mathrm{mg} / \mathrm{kg})\end{array}$ & $\begin{array}{l}\text { TCLP } \\
(\mathrm{mg} / \mathrm{L})\end{array}$ & $\begin{array}{c}\text { BDAT used to } \\
\text { derive treatment } \\
\text { standards } \\
\end{array}$ \\
\hline & Pentachloroethane & 5.6 & & \\
\hline & 1,2,4,5-Tetrachlorobenzene & 14.0 & & \\
\hline & Tetrachloroethene & 6.0 & & \\
\hline $\begin{array}{l}\text { K031-By-products salts generated } \\
\text { in the production of MSMA and } \\
\text { cacodylic acid }\end{array}$ & $\begin{array}{l}\text { 1,2,4-Trichlorobenzene } \\
\text { Arsenic }\end{array}$ & 19.0 & 5.6 & Vitrification \\
\hline $\begin{array}{l}\text { K032-Wastewater treatment } \\
\text { sludge from the production of } \\
\text { chlordane }\end{array}$ & $\begin{array}{l}\text { Hexachloropentadiene } \\
\text { Chlordane } \\
\text { Heptachlor }\end{array}$ & $\begin{array}{l}2.4 \\
0.26 \\
0.066\end{array}$ & & Incineration \\
\hline $\begin{array}{l}\text { K033-Wastewater and scrub water } \\
\text { from the chlorination of } \\
\text { cyclopentadiene in the production } \\
\text { of chlordane }\end{array}$ & $\begin{array}{l}\text { Heptachlor epoxide } \\
\text { Hexachlorocyclopentadiene }\end{array}$ & $\begin{array}{l}0.066 \\
2.4\end{array}$ & & Incineration \\
\hline $\begin{array}{l}\text { K034-Filter solids from the } \\
\text { hexachlorocyclopentadiene in the } \\
\text { production of chlordane }\end{array}$ & Hexachlorocyclopentadiene & 24 & & Incineration \\
\hline \multirow[t]{6}{*}{$\begin{array}{l}\text { K035-Wastewater treatment } \\
\text { sludges generated in the } \\
\text { production of creosote }\end{array}$} & $\begin{array}{l}\text { Acenaphthene } \\
\text { Anthracene } \\
\text { Benz(a)anthracene }\end{array}$ & $\begin{array}{l}3.4 \\
3.4 \\
3.4\end{array}$ & & Incineration \\
\hline & Benzo(a)pyrene & 3.4 & & \\
\hline & Chrysene & 3.4 & & \\
\hline & Dibenz(a,h)anthracene & 3.4 & & \\
\hline & Fluoranthene & 3.4 & & \\
\hline & Fluorene & 3.4 & & \\
\hline
\end{tabular}




\begin{tabular}{|c|c|c|c|c|}
\hline Hazardous waste description & $\begin{array}{l}\text { Constituents of } \\
\text { concern }\end{array}$ & $\begin{array}{c}\text { Total } \\
\text { composition } \\
(\mathrm{mg} / \mathrm{kg})\end{array}$ & $\begin{array}{l}\text { TCLP } \\
(\mathbf{m g} / \mathrm{L})\end{array}$ & $\begin{array}{l}\text { BDAT used to } \\
\text { derive treatment } \\
\text { standards }\end{array}$ \\
\hline & Ideno(1,2,3-cd)pyrene & 3.4 & & \\
\hline & Naphthalene & 3.4 & & \\
\hline & Phenanthrene & 3.4 & & \\
\hline K036-Still bottoms from toluene & $\begin{array}{l}\text { Pyrene } \\
\text { Disulfoton }\end{array}$ & $\begin{array}{l}8.2 \\
0.1\end{array}$ & & Incineration \\
\hline $\begin{array}{l}\text { K037-Wastewater treatiment } \\
\text { sludge from the production of } \\
\text { disulfoton }\end{array}$ & Toluene & 28.0 & & \\
\hline $\begin{array}{l}\text { K038-Wastewater from the } \\
\text { washing and stripping of phorate } \\
\text { production }\end{array}$ & Phorate & 0.1 & & Rotary kiln incineration \\
\hline $\begin{array}{l}\text { K039-Filter cake from the } \\
\text { filtration of diethylphosphoro- } \\
\text { dithioic acid in the production of } \\
\text { phorate }\end{array}$ & & $\begin{array}{l}\text { FSUBS; } \\
\text { or INCIN }\end{array}$ & & \\
\hline $\begin{array}{l}\text { K040_-Wastewater treatment } \\
\text { sludge from the production of } \\
\text { phorate }\end{array}$ & Phorate & 0.1 & & Rotary kiln incineration \\
\hline $\begin{array}{l}\text { K041-Wastewater treatment } \\
\text { sludge from the production of } \\
\text { toxaphene }\end{array}$ & Toxaphene & 2.6 & & Incineration \\
\hline $\begin{array}{l}\text { K042-Heavy ends or distillation } \\
\text { residues from the distillation of } \\
\text { tetrachlorobenzene in the } \\
\text { production of } 2,4,5-T\end{array}$ & $\begin{array}{l}\text { 1,2,3,5-Tetrachlorobenzene } \\
\text { o-Dichlorobenzene } \\
\text { p-Dichlorobenzene } \\
\text { Pentachlorobenzene }\end{array}$ & $\begin{array}{l}4.4 \\
4.4 \\
4.4 \\
4.4\end{array}$ & & Incineration \\
\hline
\end{tabular}




\begin{tabular}{|c|c|c|c|c|}
\hline Hazardous waste description & $\begin{array}{l}\text { Constituents of } \\
\text { concern }\end{array}$ & $\begin{array}{c}\text { Total } \\
\text { composition } \\
\text { (mg/kg) }\end{array}$ & $\begin{array}{l}\text { TCLP } \\
(\mathbf{m g} / L)\end{array}$ & $\begin{array}{l}\text { BDAT used to } \\
\text { derive treatment } \\
\text { standards }\end{array}$ \\
\hline & 1,2,4-Trichlorobenzene & 4.4 & & \\
\hline \multirow[t]{12}{*}{$\begin{array}{l}\text { K043-2,6-Dichlorophenol waste } \\
\text { from the production of 2,4-D }\end{array}$} & $\begin{array}{l}\text { 2,4-Dichlorophenol } \\
\text { 2,6-Dichlorophenol }\end{array}$ & $\begin{array}{l}0.38 \\
0.34\end{array}$ & & Incineration \\
\hline & Pentachlorophenol & 1.9 & & \\
\hline & Tetrachloroethene & 1.7 & & \\
\hline & Tetrachlorophenols (total) & 0.68 & & \\
\hline & 2,4,5-Trichlorophenol & 8.2 & & \\
\hline & 2,4,6-Trichlorophenol & 7.6 & & \\
\hline & Hexachlorodibenzo-p-dioxins & 0.001 & & \\
\hline & Hexachlorodibenzofurans & 0.001 & & \\
\hline & $\begin{array}{l}\text { Pentachlorodibenzo-p- } \\
\text { dioxins }\end{array}$ & 0.001 & & \\
\hline & Pentachlorodibenzofurans & 0.001 & & \\
\hline & Tetrachlorodibenzo-p-dioxins & 0.001 & & \\
\hline & Tetrachlorodibenzofurans & 0.001 & & \\
\hline $\begin{array}{l}\text { K044-Wastewater treatment } \\
\text { sludges from the manufacturing } \\
\text { and processing of explosives }\end{array}$ & & DEACT & & \\
\hline $\begin{array}{l}\text { K045-Spent carbon from the } \\
\text { treatment of wastewater } \\
\text { containing explosives }\end{array}$ & & DEACT & & \\
\hline
\end{tabular}




\begin{tabular}{|c|c|c|c|c|}
\hline Hazardous waste description & $\begin{array}{l}\text { Constituents of } \\
\text { concern }\end{array}$ & $\begin{array}{c}\text { Total } \\
\text { composition } \\
(\mathrm{mg} / \mathrm{kg})\end{array}$ & $\begin{array}{l}\text { TCLP } \\
(\mathrm{mg} / \mathrm{L})\end{array}$ & $\begin{array}{l}\text { BDAT used to } \\
\text { derive treatment } \\
\text { standards } \\
\end{array}$ \\
\hline $\begin{array}{l}\text { K046-Wastewater treatment } \\
\text { sludges from the manufacturing, } \\
\text { formulation, and loading of } \\
\text { lead-based initiating compounds }\end{array}$ & Lead & & 0.18 & $\begin{array}{l}\text { Stabilization (nonreactive } \\
\text { subcategory); deactiva- } \\
\text { tion followed by } \\
\text { stabilization (reactive } \\
\text { subcategory) }\end{array}$ \\
\hline $\begin{array}{l}\text { K047-Pink/red water from TNT } \\
\text { operations }\end{array}$ & & DEACT & & \\
\hline \multirow[t]{12}{*}{$\begin{array}{l}\text { K048-Dissolved air flotation } \\
\text { (DAF) float from the petroleum } \\
\text { refining industry }\end{array}$} & $\begin{array}{l}\text { Benzene } \\
\text { Benzo(a)pyrene } \\
\text { Bis(2-ethylhexyl)phthalate }\end{array}$ & $\begin{array}{r}14.0 \\
12.0 \\
7.3\end{array}$ & & $\begin{array}{l}\text { Solvent extraction or } \\
\text { incineration (organics), } \\
\text { stabilization of ash }\end{array}$ \\
\hline & Chrysene & 15.0 & & \\
\hline & Di-n-butyl phthalate & 3.6 & & \\
\hline & $\begin{array}{l}\text { Ethylbenzene } \\
\text { Naphthalene }\end{array}$ & 14.0 & & \\
\hline & $\begin{array}{l}\text { Naphthalene } \\
\text { Phenanthrene }\end{array}$ & 42.0 & & \\
\hline & $\begin{array}{l}\text { Phenanthrene } \\
\text { Phenol }\end{array}$ & 34.0 & & \\
\hline & $\begin{array}{l}\text { Phenol } \\
\text { Pyrene }\end{array}$ & 3.6 & & \\
\hline & $\begin{array}{l}\text { Pyrene } \\
\text { Toluene }\end{array}$ & $\begin{array}{l}36.0 \\
14.0\end{array}$ & & \\
\hline & $\begin{array}{l}\text { Toluene } \\
\text { Xylene(s) }\end{array}$ & $\begin{array}{l}14.0 \\
22.0\end{array}$ & & \\
\hline & $\begin{array}{l}\text { Xylene(s) } \\
\text { Cyanides (total) }\end{array}$ & $\begin{array}{r}22.0 \\
1.8\end{array}$ & & \\
\hline & Chromium (total) & & 1.7 & \\
\hline & Nickel & & 0.20 & \\
\hline $\begin{array}{l}\text { K049_Slop oil emulsion solids } \\
\text { from the petroleum refining } \\
\text { industry }\end{array}$ & $\begin{array}{l}\text { Anthracene } \\
\text { Benzene } \\
\text { Benzo(a)pyrene }\end{array}$ & $\begin{array}{l}28.0 \\
14.0 \\
12.0\end{array}$ & & $\begin{array}{l}\text { Solvent extraction or } \\
\text { incineration (organics), } \\
\text { stabilization of ash }\end{array}$ \\
\hline
\end{tabular}




\begin{tabular}{|c|c|c|c|c|}
\hline Hazardous waste description & $\begin{array}{l}\text { Constituents of } \\
\text { concern }\end{array}$ & $\begin{array}{c}\text { Total } \\
\text { composition } \\
(\mathrm{mg} / \mathrm{kg})\end{array}$ & $\begin{array}{l}\text { TCLP } \\
(\mathrm{mg} / \mathrm{L})\end{array}$ & $\begin{array}{l}\text { BDAT used to } \\
\text { derive treatment } \\
\text { standards }\end{array}$ \\
\hline & Bis(2-ethylhexyl)phthalate & 7.3 & & \\
\hline & Chrysene & 15.0 & & \\
\hline & Ethylbenzene & 14.0 & & \\
\hline & Naphthalene & 42.0 & & \\
\hline & Phenanthrene & 34.0 & & \\
\hline & Phenol & 3.6 & & \\
\hline & Pyrene & 36.0 & & \\
\hline & Toluene & 14.0 & & \\
\hline & Xylene(s) & 22.0 & & \\
\hline & Cyanides (total) & 1.8 & & \\
\hline & Chromium (total) & & 1.7 & \\
\hline & Nickel & & 0.20 & \\
\hline \multirow[t]{3}{*}{$\begin{array}{l}\text { K050-Heat exchanger bundle } \\
\text { cleaning sludge from the } \\
\text { petroleum refining industry }\end{array}$} & $\begin{array}{l}\text { Benzo(a)pyrene } \\
\text { Phenol } \\
\text { Cyanides (total) }\end{array}$ & $\begin{array}{r}12.0 \\
3.6 \\
1.8\end{array}$ & & $\begin{array}{l}\text { Solvent extraction or } \\
\text { incineration (organics), } \\
\text { stabilization of ash }\end{array}$ \\
\hline & Chromium (total) & & 1.7 & \\
\hline & Nickel & & 0.20 & \\
\hline \multirow[t]{5}{*}{$\begin{array}{l}\text { K051-API separator sludge from } \\
\text { the petroleum refining industry }\end{array}$} & $\begin{array}{l}\text { Anthracene } \\
\text { Benzene }\end{array}$ & $\begin{array}{l}28.0 \\
14.0\end{array}$ & & $\begin{array}{l}\text { Solvent extraction or } \\
\text { incineration (organics), } \\
\text { stabilization (lead) }\end{array}$ \\
\hline & Benzo(a)anthracene & 20.0 & & \\
\hline & Benzo(a)pyrene & 12.0 & & \\
\hline & Bis(2-ethylhexyl)phthalate & 7.3 & & \\
\hline & Chrysene & 15.0 & & \\
\hline
\end{tabular}




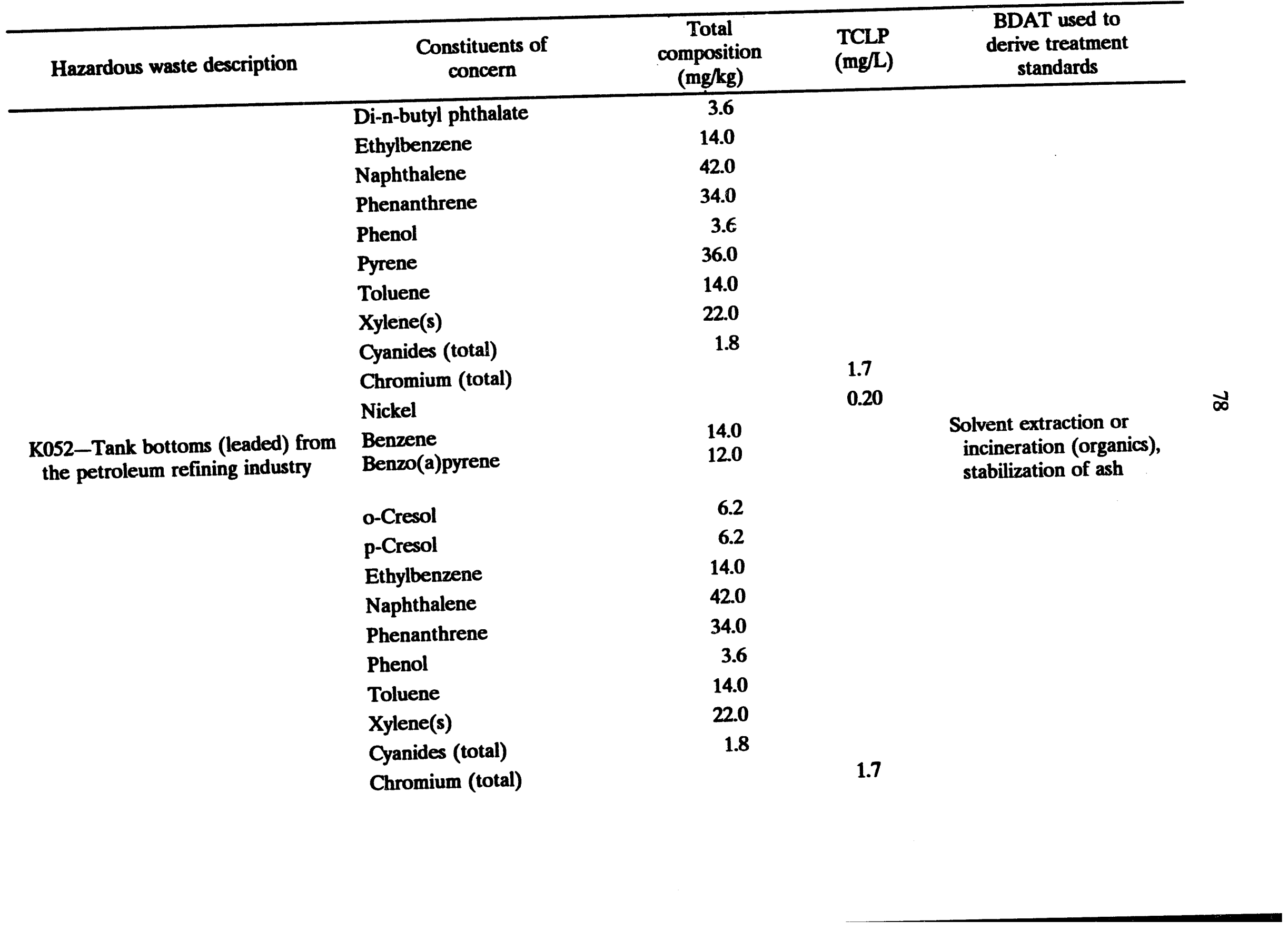




\begin{tabular}{|c|c|c|c|c|}
\hline Hazardous waste description & $\begin{array}{l}\text { Constituents of } \\
\text { concern }\end{array}$ & $\begin{array}{c}\text { Total } \\
\text { composition } \\
(\mathrm{mg} / \mathrm{kg})\end{array}$ & $\begin{array}{l}\text { TCLP } \\
(\mathrm{mg} / \mathrm{L})\end{array}$ & $\begin{array}{l}\text { BDAT used to } \\
\text { derive treatment } \\
\text { standards }\end{array}$ \\
\hline \multirow{6}{*}{$\begin{array}{l}\text { K060-Ammonia-still lime sludge } \\
\text { from coking operations }\end{array}$} & Nickel & & 0.20 & \\
\hline & Benzene & 0.071 & & Incineration \\
\hline & Benzo(a)pyrene & 3.6 & & \\
\hline & Naphthalene & 3.4 & & \\
\hline & Phenol & 3.4 & & \\
\hline & Cyanides (total) & 1.2 & & \\
\hline \multirow[t]{10}{*}{$\begin{array}{l}\text { K061-Emission control dust/ } \\
\text { sludge from the primary } \\
\text { production of steel in electric } \\
\text { furnaces }\end{array}$} & $\begin{array}{l}\text { Antimony } \\
\text { Arsenic } \\
\text { Barium } \\
\text { Beryllium }\end{array}$ & & $\begin{array}{l}2.1 \\
0.055 \\
7.6 \\
0.014\end{array}$ & $\begin{array}{l}\text { High-temperature metals } \\
\text { recovery }\end{array}$ \\
\hline & Cadmium & & 0.19 & \\
\hline & Chromium (total) & & 0.33 & \\
\hline & Lead & & 0.37 & \\
\hline & Mercury & & 0.009 & \\
\hline & Nickel & & 5.0 & \\
\hline & Selenium & & 0.16 & \\
\hline & Silver & & 0.3 & \\
\hline & Thallium & & 0.078 & \\
\hline & Zinc & & 5.3 & \\
\hline $\begin{array}{l}\text { K062-Spent pickle liquor } \\
\text { generated by steel finishing } \\
\text { operations at facilities within the } \\
\text { iron and steel industry (SIC codes }\end{array}$ & $\begin{array}{l}\text { Chromium (total) } \\
\text { Lead }\end{array}$ & & $\begin{array}{l}0.094 \\
0.37\end{array}$ & $\begin{array}{l}\text { Chromium reduction, } \\
\text { chemical precipitation, } \\
\text { filtration, sludge } \\
\text { dewatering }\end{array}$ \\
\hline
\end{tabular}




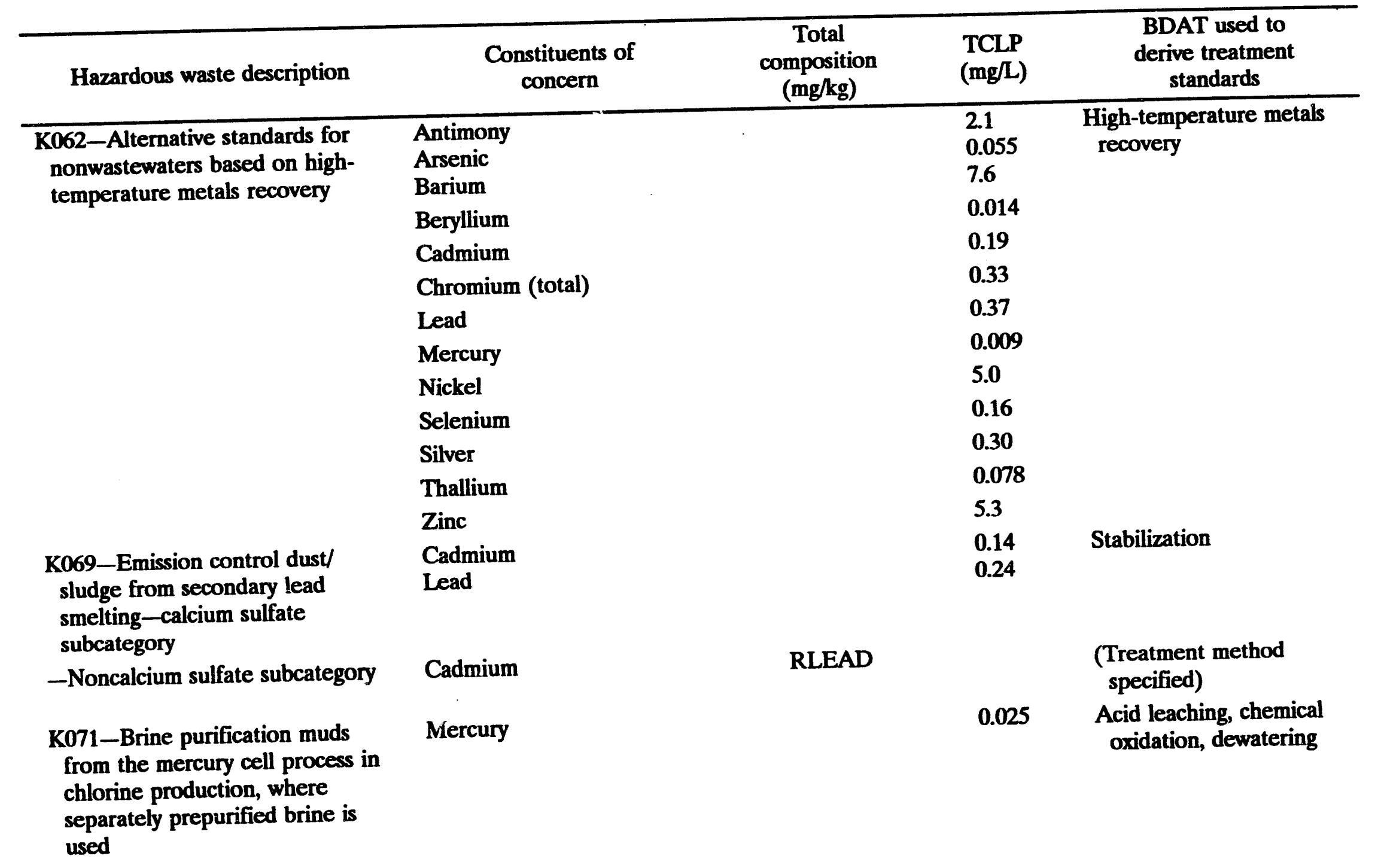




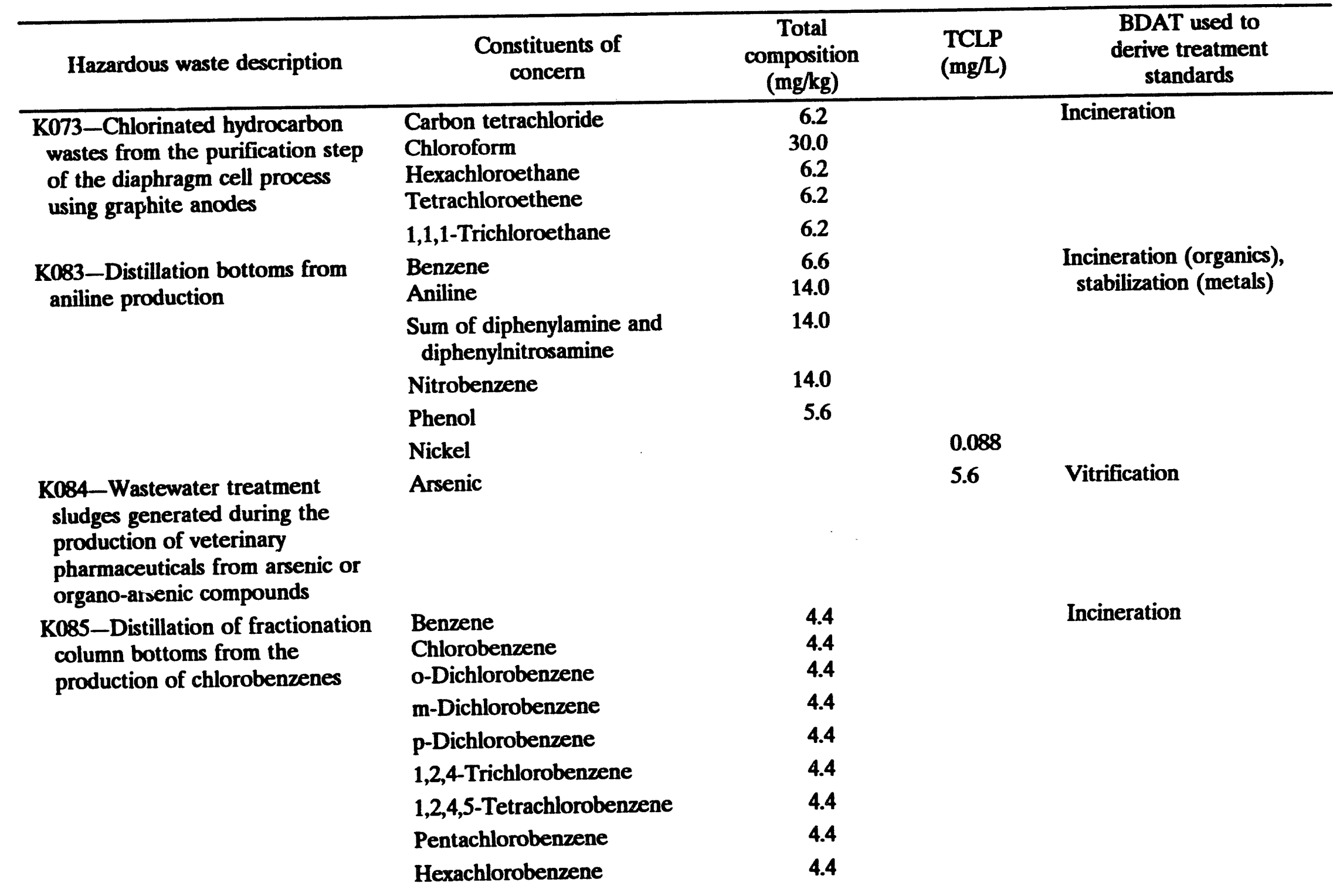




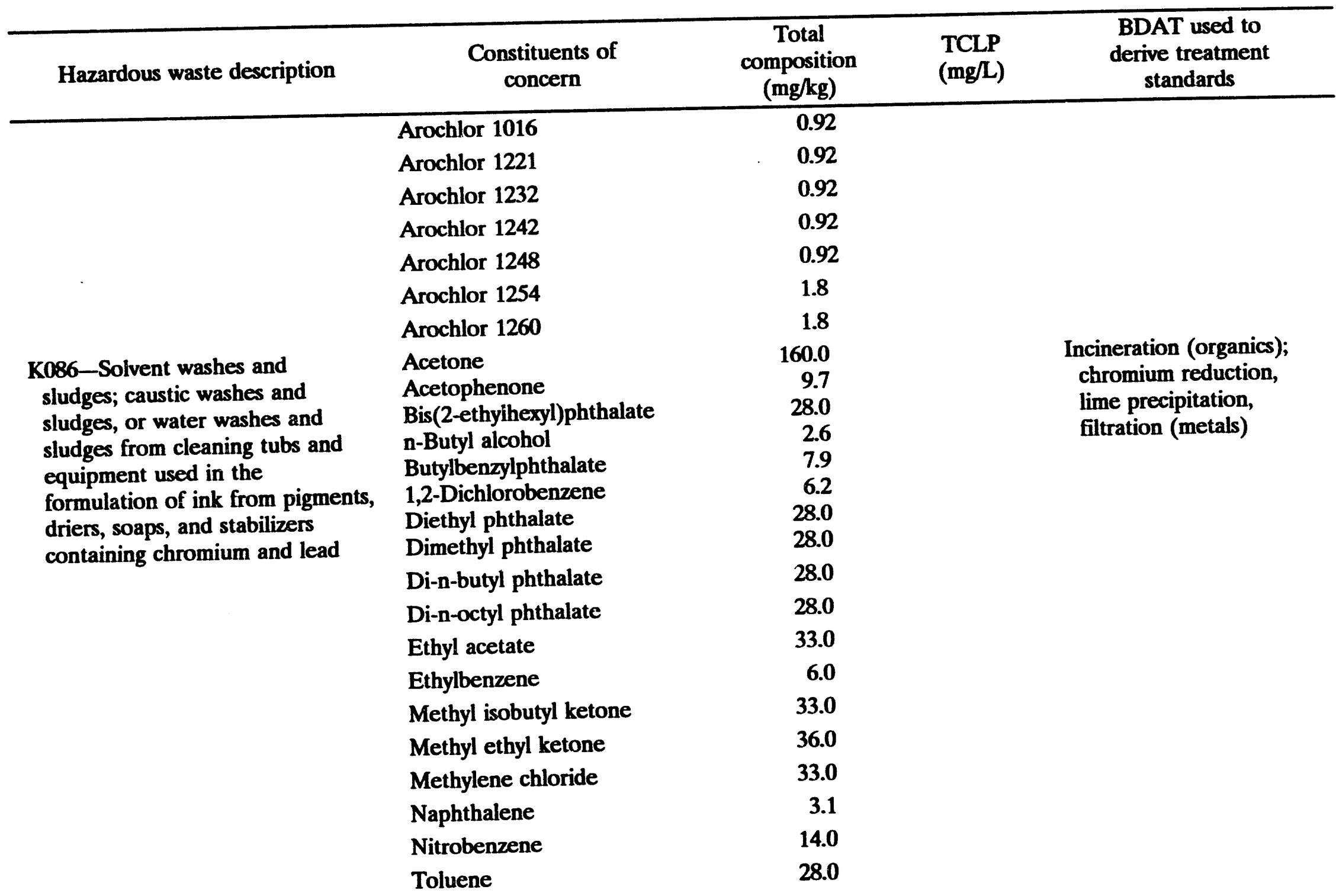




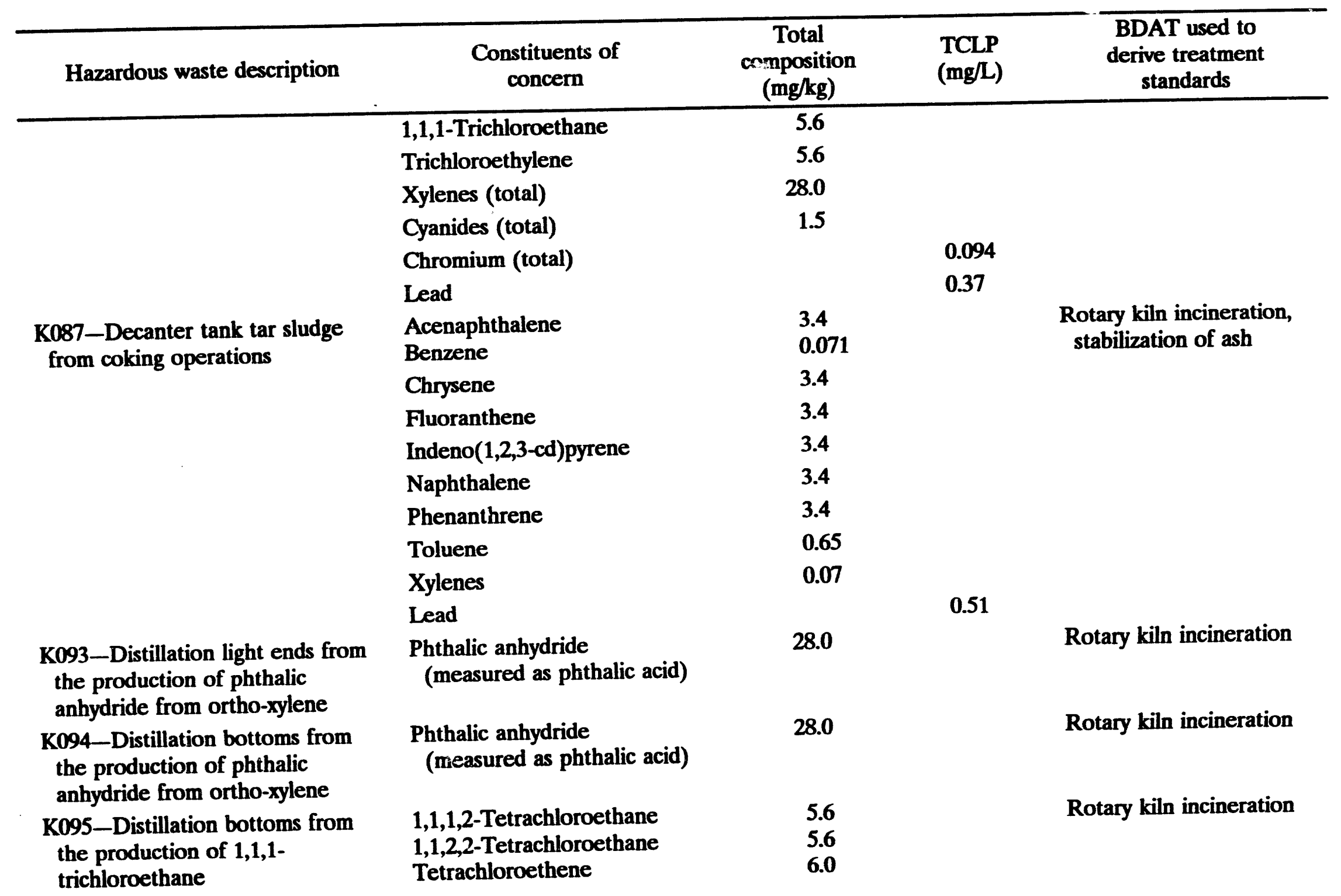




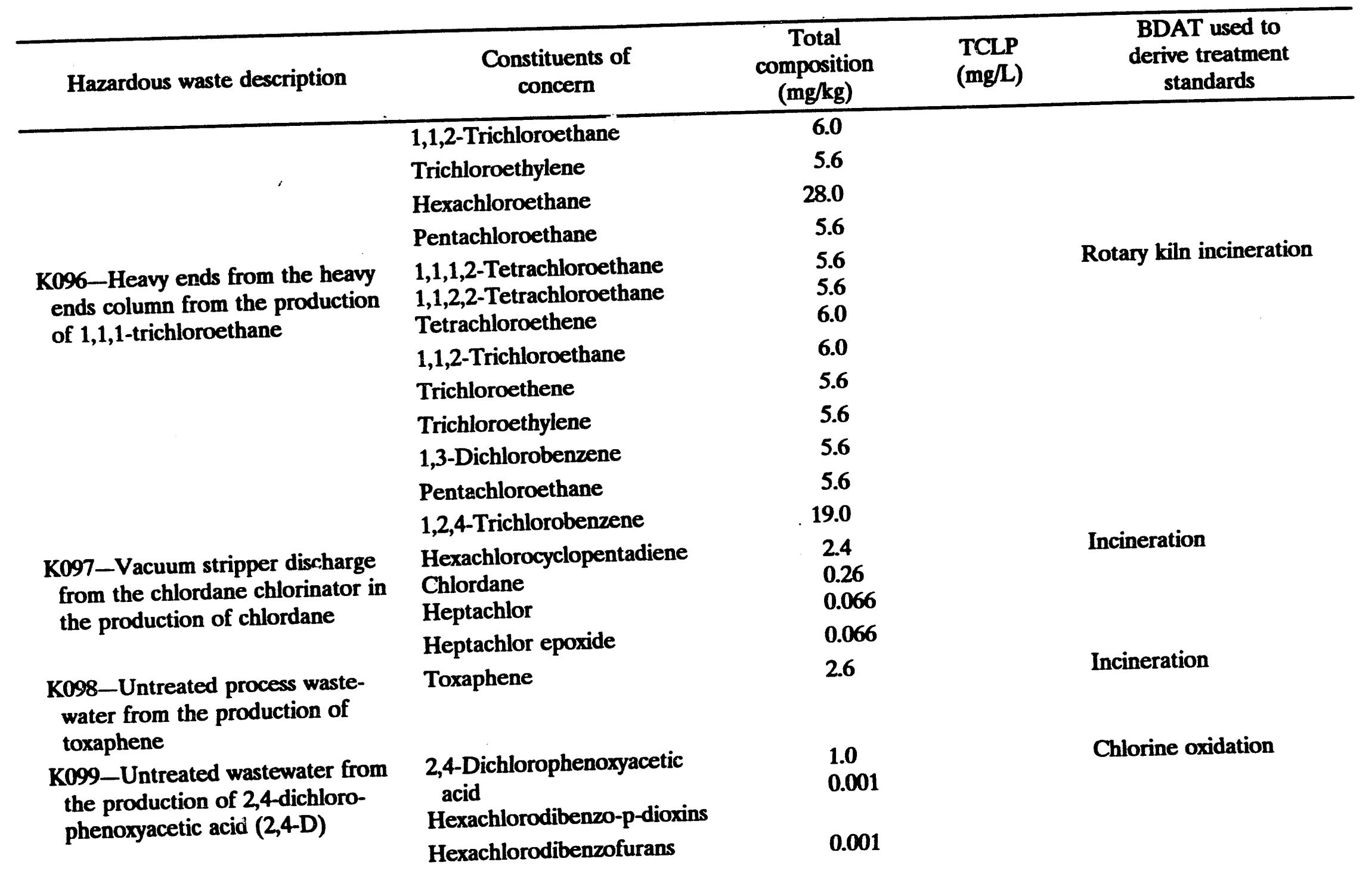




\begin{tabular}{|c|c|c|c|c|}
\hline Hazardous waste description & $\begin{array}{l}\text { Constituents of } \\
\text { concern }\end{array}$ & $\begin{array}{c}\text { Total } \\
\text { composition } \\
(\mathrm{mg} / \mathrm{kg})\end{array}$ & $\begin{array}{l}\text { TCLP } \\
(\mathrm{mg} / \mathrm{L})\end{array}$ & $\begin{array}{l}\text { BDAT used to } \\
\text { derive treatment } \\
\text { standards }\end{array}$ \\
\hline & $\begin{array}{l}\text { Pentachlorodibenzo-p- } \\
\text { dioxins }\end{array}$ & 0.001 & & \\
\hline & Pentachlorodibenzofurans & 0.001 & & \\
\hline & Tetrachlorodibenzo-p-dioxins & 0.001 & & \\
\hline & Tetrachlorodibenzofurans & 0.001 & & \\
\hline $\begin{array}{l}\text { K100-Waste leaching solution } \\
\text { from acid leaching of emission } \\
\text { control dust/sludge from } \\
\text { secondary lead smelting }\end{array}$ & $\begin{array}{l}\text { Cadmium } \\
\text { Chromium (total) } \\
\text { Lead }\end{array}$ & & $\begin{array}{l}0.066 \\
5.2 \\
0.51\end{array}$ & Stabilization \\
\hline $\begin{array}{l}\text { K101-Distillation tar residues } \\
\text { from the distillation of aniline- } \\
\text { based compounds in the produc- } \\
\text { tion of veterinary pharmaceuticals } \\
\text { from arsenic or organo-arsenic } \\
\text { compounds }\end{array}$ & $\begin{array}{l}\text { o-Nitroaniline } \\
\text { Arsenic }\end{array}$ & 14.0 & 5.6 & Vitrification \\
\hline $\begin{array}{l}\text { K102-Residue from the use of } \\
\text { activated carbon for } \\
\text { decolorization in the production } \\
\text { of veterinary pharmaceuticals } \\
\text { from arsenic or organo-arsenic } \\
\text { compounds }\end{array}$ & $\begin{array}{l}\text { o-Nitrophenol } \\
\text { Arsenic }\end{array}$ & 13.0 & 5.6 & Vitrification \\
\hline \multirow[t]{2}{*}{$\begin{array}{l}\text { K103-Process residues from } \\
\text { aniline extraction from the } \\
\text { production of aniline }\end{array}$} & $\begin{array}{l}\text { Aniline } \\
\text { Benzene } \\
\text { 2,4-Dinitrophenol } \\
\text { Nitrobenzene }\end{array}$ & $\begin{array}{l}5.6 \\
6.0 \\
5.6 \\
5.6\end{array}$ & & $\begin{array}{l}\text { Solvent extraction, } \\
\text { followed by steam } \\
\text { stripping, followed by } \\
\text { carbon adsorption }\end{array}$ \\
\hline & Phenol & 5.6 & & \\
\hline
\end{tabular}




\begin{tabular}{|c|c|c|c|c|}
\hline Hazardous waste description & $\begin{array}{l}\text { Constituents of } \\
\text { concern }\end{array}$ & $\begin{array}{c}\text { Total } \\
\text { composition } \\
(\mathrm{mg} / \mathrm{kg})\end{array}$ & $\begin{array}{l}\text { TCLP } \\
(\mathrm{mg} / \mathrm{L})\end{array}$ & $\begin{array}{l}\text { BDAT used to } \\
\text { derive treatment } \\
\text { standards }\end{array}$ \\
\hline $\begin{array}{l}\text { K104-Combined wastewater } \\
\text { streams generated from } \\
\text { nitrobenzene/aniline production }\end{array}$ & $\begin{array}{l}\text { Aniline } \\
\text { Benzene } \\
\text { Cyanides (total) } \\
\text { 2,4-Dinitrophenol } \\
\text { Nitrobenzene } \\
\text { Phenol }\end{array}$ & $\begin{array}{l}5.6 \\
6.0 \\
1.8 \\
5.6 \\
5.6 \\
4.4\end{array}$ & & $\begin{array}{l}\text { Solvent extraction, } \\
\text { followed by incinera- } \\
\text { tion, followed by } \\
\text { carbon adsorption, } \\
\text { followed by carbon } \\
\text { regeneration }\end{array}$ \\
\hline \multirow{6}{*}{$\begin{array}{l}\text { K105-Separated aqueous stream } \\
\text { from the reactor product washing } \\
\text { step in the production of } \\
\text { chlorobenzenes }\end{array}$} & Benzene & 4.4 & & Incineration \\
\hline & $\begin{array}{l}\text { Chlorobenzene } \\
\text { o-Dichlorobenzene } \\
\text { p-Dichlorobenzene }\end{array}$ & $\begin{array}{l}4.4 \\
4.4 \\
4.4\end{array}$ & & \\
\hline & 2,4,5-Trichlorophenol & 4.4 & & \\
\hline & 2,4,6-Trichlorophenol & 4.4 & & \\
\hline & 2-Chlorophenol & 4.4 & & \\
\hline & Phenol & 4.4 & & \\
\hline $\begin{array}{l}\text { K106-Wastewater treatment } \\
\text { sludge from the mercury ceil } \\
\text { process in chlorine production- } \\
\text { low-mercury subcategory } \\
(<260 \mathrm{mg} / \mathrm{kg})\end{array}$ & Mercury & & $\begin{array}{r}0.025 \\
\text { or } \mathbf{0 . 0 2 0}\end{array}$ & $\begin{array}{l}\text { Acid leaching and } \\
\text { chemical precipitation }\end{array}$ \\
\hline $\begin{array}{l}\text {-high-mercury subcategory } \\
(\geq 260 \mathrm{mg} / \mathrm{kg})\end{array}$ & Mercury & RMERC & & $\begin{array}{l}\text { (Treatment method } \\
\text { specified) }\end{array}$ \\
\hline $\begin{array}{l}\text { K107-Column bottoms from } \\
\text { product separation from the } \\
\text { production of 1,1-dimethyl- } \\
\text { hydrazine (UDMH) from } \\
\text { carboxylic acid hydrazides }\end{array}$ & & INCIN & & \\
\hline
\end{tabular}




\begin{tabular}{|c|c|c|c|c|}
\hline Hazardous waste description & $\begin{array}{l}\text { Constituents of } \\
\text { concern }\end{array}$ & $\begin{array}{c}\text { Total } \\
\text { composition } \\
(\mathbf{m g} / \mathrm{kg})\end{array}$ & $\begin{array}{l}\text { TCLP } \\
(\mathrm{mg} / \mathrm{L})\end{array}$ & $\begin{array}{c}\text { BDAT used to } \\
\text { derive treatment } \\
\text { standards }\end{array}$ \\
\hline $\begin{array}{l}\text { K108-Condensed column over- } \\
\text { heads from product separation } \\
\text { and condensed reactor vent gases } \\
\text { from the production of } \\
\text { 1,1-dimethyi-hydrazine (IDMH) } \\
\text { from carboxylic acid hydrazides }\end{array}$ & & INCIN & & \\
\hline $\begin{array}{l}\text { K109-Spend filter cartridges from } \\
\text { product purification from the } \\
\text { production of } 1,1 \text {-dimethyl- } \\
\text { hydrazine (UDMH) from } \\
\text { carboxylic acid hydrazides }\end{array}$ & & INCIN & & \\
\hline $\begin{array}{l}\text { K110-Condensed column over- } \\
\text { heads from intermediate } \\
\text { separation from the production of } \\
\text { 1,1-dimethylhydrazine (UDMH) } \\
\text { from carboxylic acid hydrazides }\end{array}$ & & INCIN & & \\
\hline $\begin{array}{l}\text { K111-Product washwaters from } \\
\text { the production of dinitrotoluene } \\
\text { via nitration of toluene }\end{array}$ & $\begin{array}{l}\text { 2,4-Dinitrotoluene } \\
\text { 2,6-Dinitrotoluene }\end{array}$ & $\begin{array}{r}140.0 \\
28.0\end{array}$ & & Incineration \\
\hline $\begin{array}{l}\text { K112-Reaction by-product water } \\
\text { from the drying column in the } \\
\text { production of toluenediamine via } \\
\text { hydrogenation of dinitrotoluene }\end{array}$ & & INCIN & & \\
\hline $\begin{array}{l}\text { K113-Condensed liquid light ends } \\
\text { from the purification of } \\
\text { toluenediamine in the production } \\
\text { of toluenediamine via } \\
\text { hydrogenation of dinitrotoluene }\end{array}$ & & $\begin{array}{l}\text { FSUBS; } \\
\text { or INCIN }\end{array}$ & & \\
\hline
\end{tabular}




\begin{tabular}{|c|c|c|c|c|}
\hline Hazardous waste description & $\begin{array}{l}\text { Constituents of } \\
\text { concern }\end{array}$ & $\begin{array}{c}\text { Total } \\
\text { composition } \\
(\mathrm{mg} / \mathrm{kg})\end{array}$ & $\begin{array}{l}\text { TCLP } \\
(\mathrm{mg} / \mathrm{L})\end{array}$ & $\begin{array}{l}\text { BDAT used to } \\
\text { derive treatment } \\
\text { standards }\end{array}$ \\
\hline $\begin{array}{l}\text { K114-Vicinals from the } \\
\text { purification of toluenediamine in } \\
\text { the production of toluenediamine } \\
\text { via hydrogenation of } \\
\text { dinitrotoluene }\end{array}$ & & $\begin{array}{l}\text { FSUBS; } \\
\text { or INCIN }\end{array}$ & \multirow{6}{*}{0.32} & \multirow{4}{*}{ Stabilization (nickel) } \\
\hline $\begin{array}{l}\text { K115-Heavy ends from the } \\
\text { purification of toluenediamine in }\end{array}$ & & $\begin{array}{c}\text { FSUBS; } \\
\text { or INCIN }\end{array}$ & & \\
\hline $\begin{array}{l}\text { the production of toluenediamine } \\
\text { via hydrogenation of } \\
\text { dinitrotoluene }\end{array}$ & Nickel & & & \\
\hline $\begin{array}{l}\text { K116-Organic condensate from } \\
\text { the solvent recovery column in } \\
\text { the production of toluene } \\
\text { diisocyanate via phosgenation of } \\
\text { toluenediamine }\end{array}$ & & $\begin{array}{c}\text { FSUBS; } \\
\text { or INCIN }\end{array}$ & & \\
\hline $\begin{array}{l}\text { K117-Wastewater from the } \\
\text { reactor vent gas scrubber in the } \\
\text { production of ethylene dibromide } \\
\text { via bromination of ethene }\end{array}$ & $\begin{array}{l}\text { Chloroform } \\
\text { Ethylene dibromide } \\
\text { Methyl bromide }\end{array}$ & $\begin{array}{r}5.6 \\
15.0 \\
15.0\end{array}$ & & \multirow[t]{2}{*}{ Incineration } \\
\hline $\begin{array}{l}\text { via bromination of ethene } \\
\text { K118-Spent adsorbent solids from } \\
\text { purification of ethylene dibromide } \\
\text { in the production of ethylene } \\
\text { dibromide via bromination of } \\
\text { ethene }\end{array}$ & $\begin{array}{l}\text { Chloroform } \\
\text { Ethylene dibromide } \\
\text { Methyl bromide }\end{array}$ & $\begin{array}{r}5.6 \\
15.0 \\
15.0\end{array}$ & & \\
\hline
\end{tabular}




\begin{tabular}{|c|c|c|c|c|}
\hline Hazardous waste description & $\begin{array}{l}\text { Constituents of } \\
\text { concern }\end{array}$ & $\begin{array}{c}\text { Total } \\
\text { composition } \\
(\mathrm{mg} / \mathrm{kg}) \\
\end{array}$ & $\begin{array}{l}\text { TCLP } \\
(\mathrm{mg} / \mathrm{L})\end{array}$ & $\begin{array}{c}\text { BDAT used to } \\
\text { derive treatment } \\
\text { standards }\end{array}$ \\
\hline $\begin{array}{l}\text { K123-Process wastewater } \\
\text { (including supernates, filtrates, } \\
\text { and washwwaters) from the produc- } \\
\text { tion of ethylenebisdithiocarbamic } \\
\text { acid and its salts }\end{array}$ & & INCIN & & \\
\hline $\begin{array}{l}\text { K124-Reactor vent scrubber water } \\
\text { from the production of ethylene- } \\
\text { bisdithiocarbamic acid and its } \\
\text { salts }\end{array}$ & & INCIN & & \\
\hline $\begin{array}{l}\text { K125-Filtration, evaporation, and } \\
\text { centrifugation solids from the } \\
\text { production of ethylenebisdi- } \\
\text { thiocarbamic acid and its salts }\end{array}$ & & INCIN & & \\
\hline $\begin{array}{l}\text { K126-Baghouse dust and floor } \\
\text { sweepings in milling and } \\
\text { packaging operations from the } \\
\text { production or formulation of } \\
\text { ethylenebisdithiocarbamic acid } \\
\text { and its salts }\end{array}$ & & INCIN & & \\
\hline $\begin{array}{l}\text { K131-Wastewater from the } \\
\text { reactor and spent sulfuric acid } \\
\text { from the acid dryer from the } \\
\text { production of methyl bromide }\end{array}$ & Methyl bromide & 15.0 & & Incineration \\
\hline $\begin{array}{l}\text { K132-Spent absorbent and } \\
\text { wastewater separator solids from } \\
\text { the production of methyl bromide }\end{array}$ & Methyl bromide & 15.0 & & Incineration \\
\hline
\end{tabular}



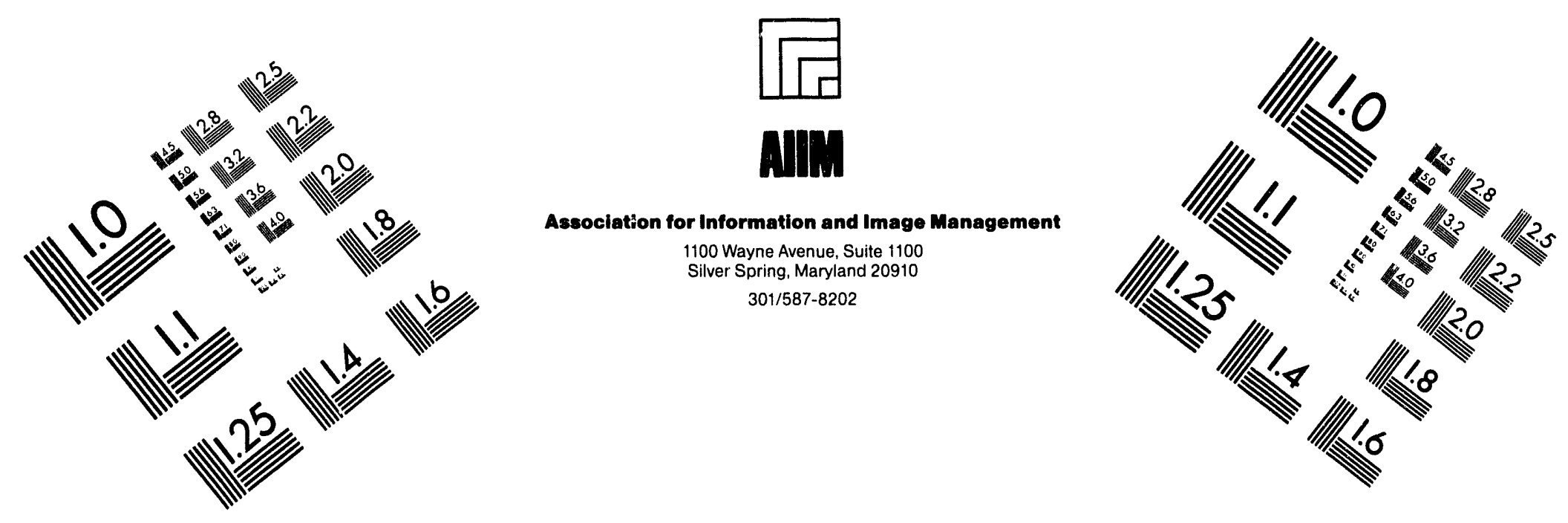

Centimeter

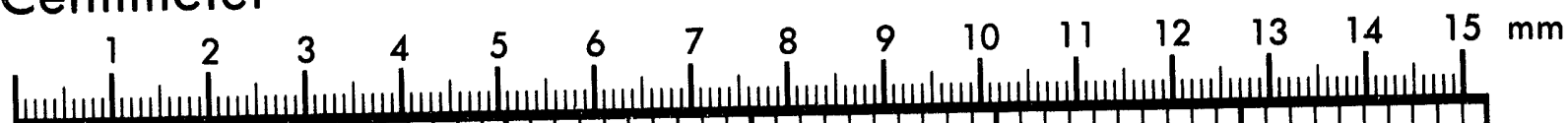

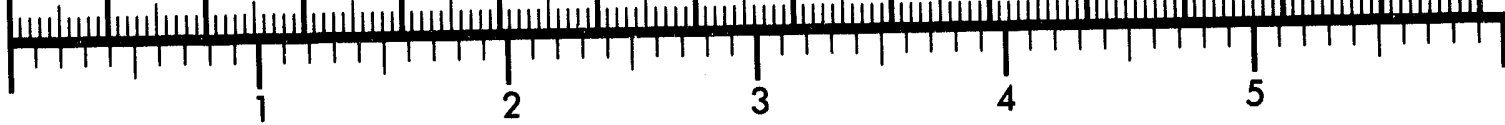
Inches
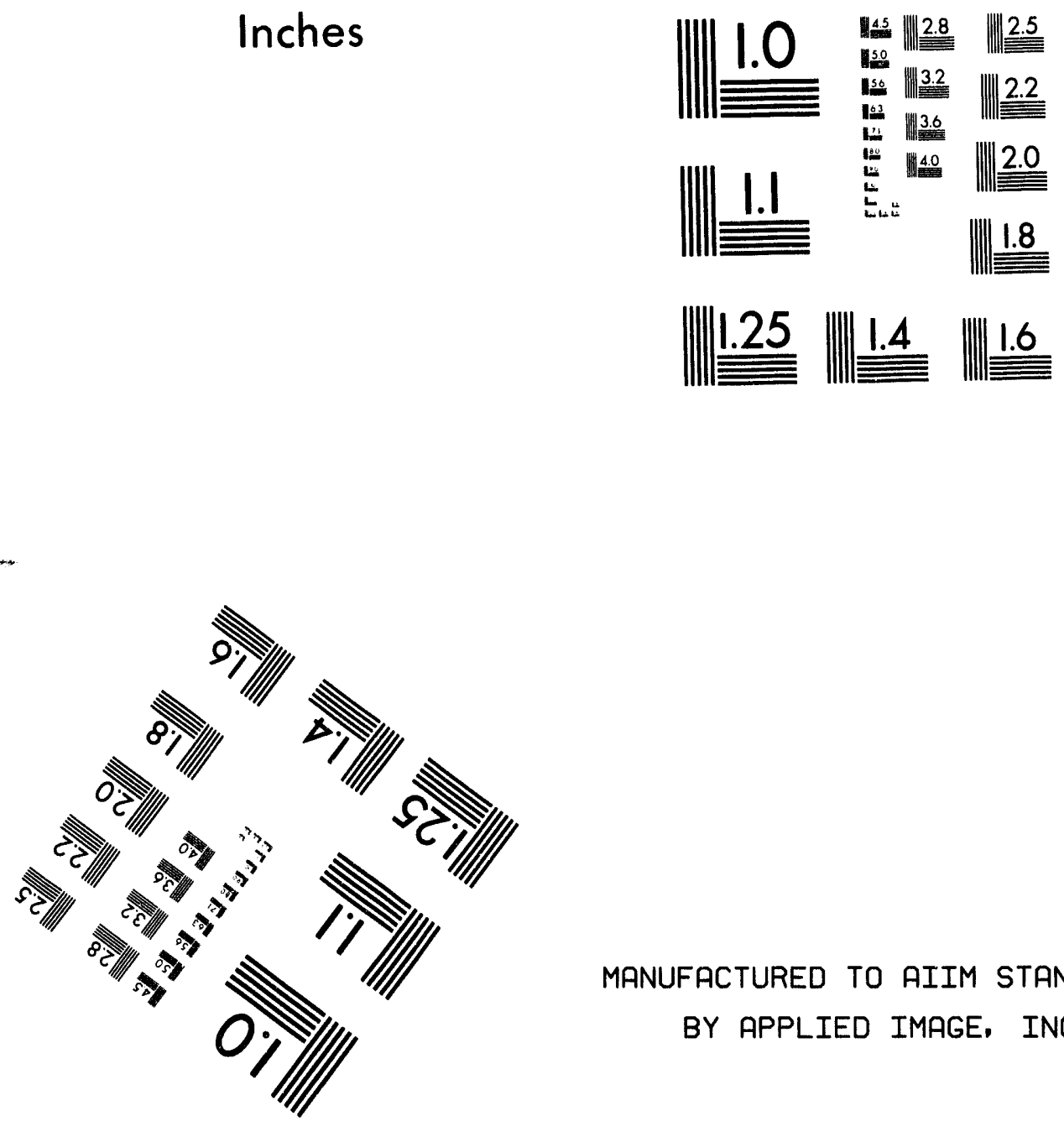

MANUFACTURED TO AIIM STANDARDS

BY APPLIED IMAGE, INC.

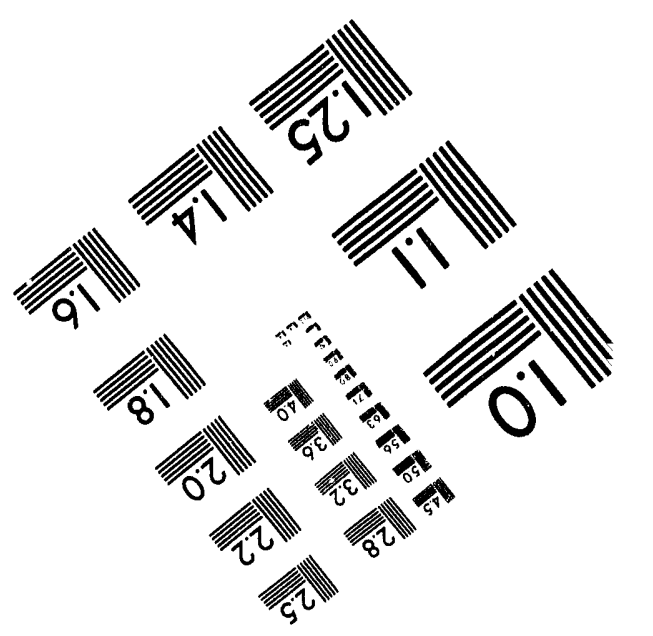





\begin{tabular}{|c|c|c|c|c|}
\hline Hazardous waste description & $\begin{array}{l}\text { Constituents of } \\
\text { concern }\end{array}$ & $\begin{array}{c}\text { Total } \\
\text { composition } \\
(\mathrm{mg} / \mathrm{kg})\end{array}$ & $\begin{array}{l}\text { TCLP } \\
(\mathrm{mg} / \mathrm{L})\end{array}$ & $\begin{array}{c}\text { BDAT used to } \\
\text { derive treatment } \\
\text { standards }\end{array}$ \\
\hline $\begin{array}{l}\text { K136-Still bottoms from the } \\
\text { purification of ethylene dibromide } \\
\text { in the production of ethylene } \\
\text { dibromide via bromination of } \\
\text { ethene }\end{array}$ & $\begin{array}{l}\text { Chloroform } \\
\text { Ethylene dibromide } \\
\text { Methyl bromide }\end{array}$ & $\begin{array}{r}5.6 \\
15.0 \\
15.0\end{array}$ & & Incineration \\
\hline $\begin{array}{l}\text { P001-Warfarin, when present at } \\
\text { concentration greater than } 0.3 \%\end{array}$ & & $\begin{array}{l}\text { FSUBS; } \\
\text { or INCIN }\end{array}$ & & \\
\hline $\begin{array}{l}\text { P002-1-Acetyl-2-thiourea } \\
\text { P003-Acrolein }\end{array}$ & & $\begin{array}{l}\text { INCIN } \\
\text { ESUBS: }\end{array}$ & & \\
\hline P003-Acrolein & & or INCIN & & \\
\hline $\begin{array}{l}\text { P004-Aldrin } \\
\text { P005-Allyl alcohol }\end{array}$ & Aldrin & $\begin{array}{c}0.066 \\
\text { FSUBS; } \\
\text { or INCIN }\end{array}$ & & Incineration \\
\hline P006-Aluminum phosphide & & $\begin{array}{l}\text { CHOXD; } \\
\text { CHRED; } \\
\text { or INCIN }\end{array}$ & & \\
\hline P007-5-Aminoethyl-3-isoxazolol & & INCIN & & \\
\hline P008-4-Aminopyridine & & INCIN & & \\
\hline P009-Ammonium picrate & & $\begin{array}{l}\text { FSUBS; } \\
\text { CHOXD; } \\
\text { CHRED; or } \\
\text { INCIN }\end{array}$ & & \\
\hline P010-Arsenic acid $\mathrm{H}_{3} \mathrm{AsO}_{4}$ & Arsenic & & 5.6 & Vitrification \\
\hline P011-Arsenic oxide $\mathrm{As}_{2} \mathrm{O}_{5}$ & Arsenic & & 5.6 & Vitrification \\
\hline P012-Arsenic oxide $\mathrm{As}_{2} \mathrm{O}_{3}$ & Arsenic & & 5.6 & Vitrification \\
\hline
\end{tabular}




\begin{tabular}{|c|c|c|c|c|}
\hline Hazardous waste description & $\begin{array}{l}\text { Constituents of } \\
\text { concern }\end{array}$ & $\begin{array}{c}\text { Total } \\
\text { composition } \\
(\mathrm{mg} / \mathrm{kg})\end{array}$ & $\begin{array}{l}\text { TCLP } \\
(\mathrm{mg} / \mathrm{L})\end{array}$ & $\begin{array}{l}\text { BDAT used to } \\
\text { derive treatment } \\
\text { standards }\end{array}$ \\
\hline P013-Barium cyanide & $\begin{array}{l}\text { Barium } \\
\text { Cyanide (total) } \\
\text { Cyanide (amendable) }\end{array}$ & $\begin{array}{r}110.0 \\
9.1\end{array}$ & 52.0 & $\begin{array}{l}\text { Electrolyte oxidation } \\
\text { followed by alkaline } \\
\text { chlorination (cyanides); } \\
\text { stabilization (metals) }\end{array}$ \\
\hline P014-Thiophenol (Benzene thiol) & & INCIN & & \\
\hline P015-Beryllium dust & & $\begin{array}{l}\text { RMETL; } \\
\text { or RTFiRM }\end{array}$ & & \\
\hline P016-Bis(chloromethyl)ether & & INCIN & & \\
\hline P017-Bromoacetone & & INCIN & & \\
\hline P018-Brucine & & INCIN & & \\
\hline P020-Dinoseb & $\begin{array}{l}\text { 2-sec-Butyl-4,6-dinitrophenol } \\
\text { (Dinoseb) }\end{array}$ & 2.5 & & Incineration \\
\hline P021-Calcium cyanide & $\begin{array}{l}\text { Cyanide (total) } \\
\text { Cyanide (amenable) }\end{array}$ & $\begin{array}{r}110.0 \\
9.1\end{array}$ & & $\begin{array}{l}\text { Electrolytic oxidation } \\
\text { followed by alkaline } \\
\text { chlorination (cyanides); } \\
\text { chemical precipitation, } \\
\text { settling, filtration } \\
\text { (metals) }\end{array}$ \\
\hline P022_Carbon disulfide & & INCIN & & $\begin{array}{l}\text { (Treatment method } \\
\text { specified) }\end{array}$ \\
\hline P023_Chloroacetaldehyde & & INCIN & & \\
\hline P024-p-Chloroaniline & p-Chloroaniline & 16.0 & & Incineration \\
\hline P026-1-(o-Chlorophenyl)thiourea & & INCIN & & \\
\hline P027-3-Chloropropionitrile & & INCIN & & \\
\hline P028-Benzyl chloride & & INCIN & & \\
\hline
\end{tabular}




\begin{tabular}{|c|c|c|c|c|}
\hline Hazardous waste description & $\begin{array}{l}\text { Constituents of } \\
\text { concern }\end{array}$ & $\begin{array}{c}\text { Total } \\
\text { composition } \\
(\mathrm{mg} / \mathrm{kg})\end{array}$ & $\begin{array}{l}\text { TCLP } \\
(\mathrm{mg} / \mathrm{L})\end{array}$ & $\begin{array}{c}\text { BDAT used to } \\
\text { derive treatment } \\
\text { standards }\end{array}$ \\
\hline P029-Copper cyanides & $\begin{array}{l}\text { Cyanide (total) } \\
\text { Cyanide (amenable) }\end{array}$ & $\begin{array}{r}110.0 \\
9.1\end{array}$ & & $\begin{array}{l}\text { Electrolytic oxidation } \\
\text { followed by alkaline } \\
\text { chlorination (cyanides); } \\
\text { chemical precipitation, } \\
\text { settling, filtration } \\
\text { (metals) }\end{array}$ \\
\hline $\begin{array}{l}\text { P030-Cyanides (soluble salts and } \\
\text { complexes) }\end{array}$ & $\begin{array}{l}\text { Cyanide (total) } \\
\text { Cyanide (amendable) }\end{array}$ & $\begin{array}{r}110.0 \\
9.1\end{array}$ & & $\begin{array}{l}\text { Electrolytic oxidation } \\
\text { followed by alkaline } \\
\text { chlorination (cyanides); } \\
\text { chemical precipitation, } \\
\text { settling, filtration } \\
\text { (metals) }\end{array}$ \\
\hline P031-Cyanogen & & $\begin{array}{l}\text { CHOXD; } \\
\text { WETOX; } \\
\text { or INCIN }\end{array}$ & & \\
\hline P033-Cyanogen chloride & & $\begin{array}{l}\text { CHOXD; } \\
\text { WETOX; } \\
\text { or INCIN }\end{array}$ & & \\
\hline $\begin{array}{l}\text { P034-2-Cyclohexyl-4,6- } \\
\text { dinitrophenol }\end{array}$ & & INCIN & & \\
\hline P036-Dichlorophenylarsine & Arsenic & & 5.6 & Vitrification \\
\hline P037-Dieldrin & Dieldrin & 0.13 & & Incineration \\
\hline P038-Diethylarsine & Arsenic & & 5.6 & Vitrification \\
\hline P039-Disulfoton & & 0.10 & & Rotary kiln incineration \\
\hline $\begin{array}{l}\text { P040-O,O-Diethyl-o-pyrazinyl } \\
\text { phosphorothioate }\end{array}$ & & $\begin{array}{l}\text { FSUBS; } \\
\text { or INCIN }\end{array}$ & & \\
\hline
\end{tabular}




\begin{tabular}{|c|c|c|c|c|}
\hline Hazardous waste description & $\begin{array}{l}\text { Constituents of } \\
\text { concern }\end{array}$ & $\begin{array}{c}\text { Total } \\
\text { composition } \\
(\mathrm{mg} / \mathrm{kg})\end{array}$ & $\begin{array}{l}\text { TCLP } \\
(\mathrm{mg} / \mathrm{L})\end{array}$ & $\begin{array}{l}\text { BDAT used to } \\
\text { derive treatment } \\
\text { standards }\end{array}$ \\
\hline $\begin{array}{l}\text { P041-Diethyl-p-nitrophenyl } \\
\text { phosphate }\end{array}$ & & $\begin{array}{l}\text { FSUBS; } \\
\text { or INCIN }\end{array}$ & & \\
\hline P042-Epinephrine & & INCIN & & \\
\hline $\begin{array}{l}\text { P043-Diisopropyl fluorophosphate } \\
\text { (DPF) }\end{array}$ & & $\begin{array}{l}\text { FSUBS; } \\
\text { or INCIN }\end{array}$ & & \\
\hline P044-Dimethoate & & $\begin{array}{l}\text { FSUBS; } \\
\text { or INCIN }\end{array}$ & & \\
\hline P045-Thiofanox & & INCIN & & \\
\hline $\begin{array}{l}\text { P046-Alpha, alpha- } \\
\text { Dimethylphenethylamine }\end{array}$ & & INCIN & & \\
\hline P047-4,6-Dinitrocresol & 4,6-Dinitro-o-cresol & 160.0 & & Incineration \\
\hline P047-4,6-Dinitrocresol salts & & INCIN & & \\
\hline P048-2,4-Dinitrophenol & 2,4-Dinitrophenol & 160.0 & & Incineration \\
\hline P049-2,4-Dithiobiuret & & INCIN & & \\
\hline \multirow{3}{*}{ P050-Endosulfan } & Endosulfan I & 0.066 & & Incineration \\
\hline & Endosulfan II & 0.13 & & \\
\hline & Endosulfan sulfate & 0.13 & & \\
\hline \multirow[t]{2}{*}{ P051-Endrin } & Endrin & 0.13 & & Incineration \\
\hline & Endrin aldehyde & 0.13 & & \\
\hline $\begin{array}{l}\text { P054-Aziridine } \\
\text { P056-Fluorine }\end{array}$ & Fluoride & $\begin{array}{c}\text { INCIN } \\
\text { ADGAS } \\
\text { fb NEUTR }\end{array}$ & & $\begin{array}{l}\text { (Treatment method } \\
\text { specified) }\end{array}$ \\
\hline P057-Fluoracetamide & & INCIN & & \\
\hline P058-Fluoracetic acid, sodium salt & & INCIN & & \\
\hline
\end{tabular}




\begin{tabular}{|c|c|c|c|c|}
\hline Hazardous waste description & $\begin{array}{l}\text { Constituents of } \\
\text { concern }\end{array}$ & $\begin{array}{c}\text { Total } \\
\text { composition } \\
(\mathrm{mg} / \mathrm{kg}) \\
\end{array}$ & $\begin{array}{l}\text { TCLP } \\
(\mathrm{mg} / \mathrm{L})\end{array}$ & $\begin{array}{l}\text { BDAT used to } \\
\text { derive treatment } \\
\text { standards }\end{array}$ \\
\hline P059-Heptachlor & Heptachlor & 0.066 & & Incineration \\
\hline & Heptachlor epoxide & 0.066 & & \\
\hline $\begin{array}{l}\text { P060-Isodrin } \\
\text { PO62-Hexaethyltetraphosphate }\end{array}$ & Isodrin & 0.066 & & Incineration \\
\hline P062-Hexaethyltetraphosphate & & $\begin{array}{l}\text { FSUBS; } \\
\text { or INCIN }\end{array}$ & & \\
\hline P063-Hydrogen cyanide & $\begin{array}{l}\text { Cyanide (total) } \\
\text { Cyanide (amenable) }\end{array}$ & $\begin{array}{r}110.0 \\
9.1\end{array}$ & & $\begin{array}{l}\text { Electrolytic oxidation } \\
\text { followed by alkaline } \\
\text { chlorination (cyanides); } \\
\text { chemical precipitation, } \\
\text { settling, filtration } \\
\text { (metals) }\end{array}$ \\
\hline P064-Isocyanic acid, ethyl ester & & INCIN & & \\
\hline $\begin{array}{l}\text { P065-Mercury fulminate } \\
\text {-High-mercury subcategory } \\
\text { ( } 2260 \mathrm{mg} / \mathrm{kg} \text { mercury) }\end{array}$ & Mercury & $\begin{array}{l}\text { RMERC; } \\
\text { or IMERC }\end{array}$ & & \\
\hline $\begin{array}{l}\text { - Low-mercury subcategory } \\
\text { (<260 mg/kg mercury) }\end{array}$ & Mercury & $\begin{array}{l}\text { RMERC; } \\
\text { or IMERC }\end{array}$ & & $\begin{array}{l}\text { Acid leaching, chemical } \\
\text { precipitation }\end{array}$ \\
\hline P066-Methomyl & & INCIN & & \\
\hline P067-2-Methylaziridine & & INCIN & & \\
\hline P068-Methyl hydrazine & & $\begin{array}{l}\text { FSUBS; } \\
\text { CHOXD; } \\
\text { CHRED; or } \\
\text { INCIN }\end{array}$ & & \\
\hline P069-Methyllactonitrile & & INCIN & & \\
\hline P070-Aldicarb & & INCIN & & \\
\hline P071-Methyl parathion & Methyl parathion & 0.1 & & Rotary kiln incineration \\
\hline
\end{tabular}




\begin{tabular}{|c|c|c|c|c|}
\hline Hazardous waste description & $\begin{array}{l}\text { Constituents of } \\
\text { concern }\end{array}$ & $\begin{array}{c}\text { Total } \\
\text { composition } \\
(\mathrm{mg} / \mathrm{kg})\end{array}$ & $\begin{array}{l}\text { TCLP } \\
(\mathrm{mg} / \mathrm{L})\end{array}$ & $\begin{array}{l}\text { BDAT used to } \\
\text { derive treatment } \\
\text { standards }\end{array}$ \\
\hline P072-1-Naphthyl-2-thiourea & & INCIN & & \\
\hline P073-Nickel carbonyl & Nickel & & 0.32 & Stabilization \\
\hline P074-Nickel cyanide & $\begin{array}{l}\text { Cyanide (total) } \\
\text { Cyanide (amendable) } \\
\text { Nickel }\end{array}$ & $\begin{array}{r}110.0 \\
9.1\end{array}$ & 0.32 & $\begin{array}{l}\text { Electrolytic oxidation } \\
\text { followed by alkaline } \\
\text { chlorination (cyanides); } \\
\text { chemical precipitation, } \\
\text { settling, filtration, } \\
\text { stabilization (metals) }\end{array}$ \\
\hline P075-Nicotine and salts & & INCIN & & \\
\hline P076-Nitric oxide & & ADGAS & & \\
\hline P077-p-Nitroaniline & p-Nitroaniline & 28.0 & & Incineration \\
\hline P078-Nitrogen dioxide & & ADGAS & & \\
\hline P081-Nitroglycerine & & $\begin{array}{l}\text { FSUBS; } \\
\text { CHOXD; } \\
\text { CHRED: or } \\
\text { INCIN }\end{array}$ & & \\
\hline P082-N-Nitrosodimethylamine & N-Nitrosodimethylamine & INCIN & & $\begin{array}{l}\text { (Treatment method } \\
\text { specified) }\end{array}$ \\
\hline P084-N-Nitrosomethylvinylamine & & INCIN & & \\
\hline $\begin{array}{l}\text { P085-Octamethylpyro- } \\
\text { phosphoramide }\end{array}$ & & $\begin{array}{l}\text { FSUBS; } \\
\text { or INCIN }\end{array}$ & & \\
\hline P087-Osmium tetraoxide & & $\begin{array}{l}\text { RMETL; } \\
\text { or RTHRM }\end{array}$ & & \\
\hline P088-Endothall & & $\begin{array}{l}\text { FSUBS; } \\
\text { or INCIN }\end{array}$ & & \\
\hline P089-Parathion & Parathion & 0.1 & & Rotary kiln incineration \\
\hline
\end{tabular}




\begin{tabular}{|c|c|c|c|c|}
\hline Hazardous waste description & $\begin{array}{l}\text { Constituents of } \\
\text { concern }\end{array}$ & $\begin{array}{c}\text { Total } \\
\text { composition } \\
\text { (mg/kg) }\end{array}$ & $\begin{array}{l}\text { TCLP } \\
(\mathrm{mg} / \mathrm{L})\end{array}$ & $\begin{array}{l}\text { BDAT used to } \\
\text { derive treatment } \\
\text { standards }\end{array}$ \\
\hline \multicolumn{5}{|l|}{ P092-Phenylmercuric acetate } \\
\hline $\begin{array}{l}\text { - High-mercury subcategory } \\
\text { ( } 2260 \mathrm{mg} / \mathrm{kg} \text { mercury })\end{array}$ & Mercury & RMERC & & \\
\hline $\begin{array}{l}\text { - Low-mercury subcategory } \\
\text { (<260 mg/kg mercury) }\end{array}$ & Mercury & $\begin{array}{l}\text { RMERC; } \\
\text { or IMERC }\end{array}$ & $\begin{array}{l}0.20 \\
0.025\end{array}$ & $\begin{array}{l}\text { Acid leaching, chemical } \\
\text { precipitation }\end{array}$ \\
\hline $\begin{array}{l}\text { P093-N-Phenylthiourea } \\
\text { P094-Phorate }\end{array}$ & & $\begin{array}{c}\text { INCIN } \\
0.1\end{array}$ & & \\
\hline $\begin{array}{l}\text { P094-Phorate } \\
\text { P095-Phosgene }\end{array}$ & Phorate & $\begin{array}{c}0.1 \\
\text { INCIN }\end{array}$ & & Rotary kiln incineration \\
\hline $\begin{array}{l}\text { P095-Phosgene } \\
\text { P096-Phosphine }\end{array}$ & & $\begin{array}{c}\text { INCIN } \\
\text { CHOXD; }\end{array}$ & & \\
\hline P096-Phospnine & & $\begin{array}{l}\text { CHOXD; } \\
\text { CHRED; } \\
\text { or INCIN }\end{array}$ & & \\
\hline P097-Famphur & Famphur & 0.1 & & Rotary kiln incineration \\
\hline P098-Potassium cyanide & $\begin{array}{l}\text { Cyanide (total) } \\
\text { Cyanide (amenable) }\end{array}$ & $\begin{array}{r}110.0 \\
9.1\end{array}$ & & $\begin{array}{l}\text { Electrolytic oxidation } \\
\text { followed by alkaline } \\
\text { chlorination (cyanides); } \\
\text { chemical precipitation, } \\
\text { settling, filtration } \\
\text { (metals) }\end{array}$ \\
\hline P099_Potassium silver cyanide & $\begin{array}{l}\text { Silver } \\
\text { Cyanide (total) } \\
\text { Cyanide (amenable) }\end{array}$ & $\begin{array}{r}110.0 \\
9.1\end{array}$ & 0.072 & $\begin{array}{l}\text { Electrolytic oxidation } \\
\text { followed by alkaline } \\
\text { chlorination (cyanides); } \\
\text { chemical precipitation, } \\
\text { settling, filtration, } \\
\text { stabilization (metals) }\end{array}$ \\
\hline P101-Propanenitrile & $\begin{array}{l}\text { Ethyl cyanide } \\
\text { (propanenitrile) }\end{array}$ & 360.0 & & Incineration \\
\hline
\end{tabular}




\begin{tabular}{|c|c|c|c|c|}
\hline Hazardous waste description & $\begin{array}{l}\text { Constituents of } \\
\text { concern }\end{array}$ & $\begin{array}{c}\text { Total } \\
\text { composition } \\
(\mathrm{mg} / \mathrm{kg})\end{array}$ & $\begin{array}{l}\text { TCLP } \\
(\mathrm{mg} / \mathrm{L})\end{array}$ & $\begin{array}{l}\text { BDAT used to } \\
\text { derive treatment } \\
\text { standards }\end{array}$ \\
\hline P102-Propargyl alcohol & & $\begin{array}{l}\text { FSUBS; } \\
\text { or INCIN }\end{array}$ & & \\
\hline P103-Selenourea & Selenium & & 5.7 & Stabilization \\
\hline P104_Silver cyanide & $\begin{array}{l}\text { Cyanide (total) } \\
\text { Cyanide (amenable) } \\
\text { Silver }\end{array}$ & $\begin{array}{r}110.0 \\
9.1\end{array}$ & 0.072 & $\begin{array}{l}\text { Electrolytic oxidation } \\
\text { followed by alkaline } \\
\text { chlorination (cyanides); } \\
\text { chemical precipitation, } \\
\text { settling, filtration, } \\
\text { stabilization (metals) }\end{array}$ \\
\hline P105_Sodium azide & & $\begin{array}{l}\text { FSUBS; } \\
\text { CHOXD; } \\
\text { CHRED; or } \\
\text { INCIN }\end{array}$ & & \\
\hline P106-Sodium cyanide & $\begin{array}{l}\text { Cyanide (total) } \\
\text { Cyanide (amenable) }\end{array}$ & $\begin{array}{r}110.0 \\
9.1\end{array}$ & & $\begin{array}{l}\text { Electrolytic oxidation } \\
\text { followed by alkaline } \\
\text { chlorination (cyanides); } \\
\text { chemical precipitation, } \\
\text { settling, filtration } \\
\text { (metals) }\end{array}$ \\
\hline P108-Strychnine and salts & & INCIN & & \\
\hline $\begin{array}{l}\text { P109_Tetraethyldithio- } \\
\text { pyrophosphate }\end{array}$ & & $\begin{array}{l}\text { FSUBS; } \\
\text { or INCIN }\end{array}$ & & \\
\hline P110-Tetraethyl lead & Lead & & 0.51 & $\begin{array}{l}\text { Incineration (organics); } \\
\text { stabilization (lead) }\end{array}$ \\
\hline P111-Tetraethylpyrophosphate & & $\begin{array}{l}\text { FSUBS; } \\
\text { or INCIN }\end{array}$ & & \\
\hline
\end{tabular}




\begin{tabular}{|c|c|c|c|c|}
\hline Hazardous waste description & $\begin{array}{l}\text { Constituents of } \\
\text { concern }\end{array}$ & $\begin{array}{c}\text { Total } \\
\text { composition } \\
(\mathrm{mg} / \mathrm{kg})\end{array}$ & $\begin{array}{l}\text { TCLP } \\
(\mathrm{mg} / \mathrm{L})\end{array}$ & $\begin{array}{l}\text { BDAT used to } \\
\text { derive treatment } \\
\text { standards }\end{array}$ \\
\hline P112-Tetranitromethane & & $\begin{array}{l}\text { FSUBS; } \\
\text { CHOXD; } \\
\text { CHRED; or } \\
\text { INCIN }\end{array}$ & & \\
\hline P113-Thallic oxide & Thallium & $\begin{array}{l}\text { RTHRM; } \\
\text { or STABL }\end{array}$ & & $\begin{array}{l}\text { (Treatment method } \\
\text { specified) }\end{array}$ \\
\hline P114-Thallium (I) selenite & Selenium & & 5.7 & $\begin{array}{l}\text { Stabilization, vitrification } \\
\text { or recovery }\end{array}$ \\
\hline P115-Thallium (I) sulfate & Thallium & $\begin{array}{l}\text { RTHRM; } \\
\text { or STABL }\end{array}$ & & $\begin{array}{l}\text { (Treatment method } \\
\text { specified) }\end{array}$ \\
\hline P116-Thiosemicarbazide & & INCIN & & \\
\hline $\begin{array}{l}\text { P118-Trichloromethanethiol } \\
\text { P119-Ammonium vanadate }\end{array}$ & Vanadium & $\begin{array}{l}\text { INCIN } \\
\text { STABL }\end{array}$ & & $\begin{array}{l}\text { (Treatment method } \\
\text { specified) }\end{array}$ \\
\hline P120_Vanadium pentoxide & Vanadium & STABL & & $\begin{array}{l}\text { (Treatment method } \\
\text { specified) }\end{array}$ \\
\hline P121-Zinc cyanide & $\begin{array}{l}\text { Cyanide (total) } \\
\text { Cyanide (amenable) }\end{array}$ & $\begin{array}{r}110.0 \\
9.1\end{array}$ & & $\begin{array}{l}\text { Electrolytic oxidation } \\
\text { followed by alkaline } \\
\text { chlorination (cyanides); } \\
\text { chemical precipitation, } \\
\text { settling, filtration } \\
\text { (metals) }\end{array}$ \\
\hline $\begin{array}{l}\text { P122-Zinc phosphide, when } \\
\text { present at concentrations }>10 \%\end{array}$ & & $\begin{array}{l}\text { CHOXD; } \\
\text { CHRED; } \\
\text { or INCIN }\end{array}$ & & \\
\hline P123-Toxaphene & Toxaphene & 1.3 & & Incineration \\
\hline
\end{tabular}




\begin{tabular}{|c|c|c|c|c|}
\hline Hazardous waste description & $\begin{array}{l}\text { Constituents of } \\
\text { concern }\end{array}$ & $\begin{array}{c}\text { Total } \\
\text { composition } \\
(\mathrm{mg} / \mathrm{kg})\end{array}$ & $\begin{array}{l}\text { TCLP } \\
(\mathrm{mg} / \mathrm{L})\end{array}$ & $\begin{array}{l}\text { BDAT used to } \\
\text { derive treatment } \\
\text { standards }\end{array}$ \\
\hline $\begin{array}{l}\text { U001-Acetaldehyde } \\
\text { U002-Acetone }\end{array}$ & Acetone & $\begin{array}{c}\text { INCIN } \\
160.0\end{array}$ & & $\begin{array}{l}\text { Incineration or fuel } \\
\text { substitution }\end{array}$ \\
\hline U003-Acetonitrile & Acetonitrile & $\begin{array}{l}\text { INCIN } \\
\text { and } 0.17\end{array}$ & & $\begin{array}{l}\text { (Treatment method } \\
\text { specified) }\end{array}$ \\
\hline U004-Acetophenone & Acetophenone & 9.7 & & Incineration \\
\hline U005-o-Acetylaminofluorene & 2-Acetylaminofluorene & 140.0 & & Incineration \\
\hline U006-Acetyl chloride & & INCIN & & \\
\hline U007-Acrylamide & & INCIN & & \\
\hline U008-Acrylic acid & & $\begin{array}{l}\text { FSUBS; } \\
\text { or INCIN }\end{array}$ & & \\
\hline U009-Acrylonitrile & Acrylonitrile & 84.0 & & Incineration \\
\hline U010-Mitomycin C & & INCIN & & \\
\hline U011-Amitrole & & INCIN & & \\
\hline U012-Aniline & Aniline & 14.0 & & Incineration \\
\hline U014-Auramine & & INCIN & & \\
\hline U015-Azaserine & & INCIN & & \\
\hline U016-Benz(c)acridine & & $\begin{array}{l}\text { FSUBS; } \\
\text { or INCIN }\end{array}$ & & \\
\hline U017-Benzal chloride & Benzal chloride & INCIN & & \\
\hline U018-Benz(a)anthracene & Benz(a)anthracene & 8.2 & & Incineration \\
\hline U019-Benzene & Benzene & 36.0 & & Incineration \\
\hline U020-Benzenesulfonyl chloride & & INCIN & & \\
\hline U021-Benzidine & & INCIN & & \\
\hline
\end{tabular}




\begin{tabular}{|c|c|c|c|c|}
\hline Hazardous waste description & $\begin{array}{l}\text { Constituents of } \\
\text { concern }\end{array}$ & $\begin{array}{c}\text { Total } \\
\text { composition } \\
(\mathrm{mg} / \mathrm{kg})\end{array}$ & $\begin{array}{l}\text { TCLP } \\
(\mathrm{mg} / \mathrm{L})\end{array}$ & $\begin{array}{l}\text { BDAT used to } \\
\text { derive treatment } \\
\text { standards }\end{array}$ \\
\hline U022-Benzo(a)pyrene & Benzo(a)pyrene & 8.2 & & \\
\hline U023-Benzotrichloride & & $\begin{array}{l}\text { FSUBS; } \\
\text { CHOXD; } \\
\text { CHRED; or } \\
\text { INCIN }\end{array}$ & & \\
\hline $\begin{array}{l}\text { U024-Bis(2-chloroethyoxy)- } \\
\text { methane }\end{array}$ & $\begin{array}{l}\text { Bis(2-chloroethyoxy)- } \\
\text { methane }\end{array}$ & 7.2 & & Incineration \\
\hline U025-Dichloroethyl ether & Bis(2-chloroethyl)ether & 7.2 & & Incineration \\
\hline U026-Chlonaphazine & & INCIN & & \\
\hline U027-Bis(2-chloroisopropyl)ether & Bis(2-chloroisopropyl)ether & 7.2 & & Incineration \\
\hline U028-Bis-(2-ethylhexyl)phthalate & Bis-(2-ethylhexyl)phthalate & 28.0 & & Rotary kiln incineration \\
\hline U029-Methyl bromide & $\begin{array}{l}\text { Bromomethane (Methyl } \\
\text { bromide) }\end{array}$ & 15.0 & & Incineration \\
\hline $\begin{array}{l}\text { U030-Benzene, 1-bromo-4- } \\
\text { phenoxy }\end{array}$ & 4-Bromophenyl phenyl ether & 15.0 & & Incineration \\
\hline U031-n-Butanol & n-Butyl alcohol & 2.6 & & $\begin{array}{l}\text { Incineration or fuel } \\
\text { substitution }\end{array}$ \\
\hline U032-Calcium chromate & Chromium (total) & & 0.094 & $\begin{array}{l}\text { Chromium reduction, } \\
\text { lime or sulfide } \\
\text { precipitation, sludge } \\
\text { dewatering }\end{array}$ \\
\hline U-33-Carbonyl fluoride & & INCIN & & \\
\hline U034-Chloral & & INCIN & & \\
\hline U035-Chlorambucil & & INCIN & & \\
\hline U036-Chlordane, technical & $\begin{array}{l}\text { Chlordane, alpha and } \\
\text { gamma }\end{array}$ & 0.13 & & Incineration \\
\hline
\end{tabular}




\begin{tabular}{|c|c|c|c|c|}
\hline Hazardous waste description & $\begin{array}{l}\text { Constituents of } \\
\text { concern }\end{array}$ & $\begin{array}{c}\text { Total } \\
\text { composition } \\
(\mathrm{mg} / \mathrm{kg})\end{array}$ & $\begin{array}{l}\text { TCLP } \\
(\mathrm{mg} / \mathrm{L})\end{array}$ & $\begin{array}{c}\text { BDAT used to } \\
\text { derive treatment } \\
\text { standards }\end{array}$ \\
\hline U037-Chlorobenzene & Chlorobenzene & 5.7 & & Incineration \\
\hline U038-Chlorobenzilate & & INCIN & & $\begin{array}{l}\text { (Treatment method } \\
\text { specified) }\end{array}$ \\
\hline U039-4-Chloro-m-cresol & p-Chloro-m-cresol & 14.0 & & Incineration. \\
\hline U041-1-Chloro-2,3-epoxypropane & & INCIN & & \\
\hline U042-Vinyl ether, 2-chloroethyl & 2-Chloroethyl vinyl & INCIN & & \\
\hline U043-Vinyl chloride & Vinyl chloride & 33.0 & & Incineration \\
\hline U044-Chloroform & Chloroform & 5.6 & & Incineration \\
\hline $\begin{array}{l}\text { U045-Chloromethane (methyl } \\
\text { chloride) }\end{array}$ & Chloromethane & 33.0 & & Incineration \\
\hline $\begin{array}{l}\text { U046-Chloromethyl methyl ether } \\
\text { U047-2-Chloronaphthalene }\end{array}$ & & INCIN & & \\
\hline $\begin{array}{l}\text { U047-2-Chloronaphthalene } \\
\text { U048-o-Chlorophenol }\end{array}$ & $\begin{array}{l}\text { 2-Chloronaphthaiene } \\
\text { 2-Chlorophenol }\end{array}$ & 5.6 & & Incineration \\
\hline $\begin{array}{l}\text { U048-0-Chlorophenol } \\
\text { U049-4-Chloro-0-toluidine, } \\
\text { hydrochloride }\end{array}$ & 2-Chlorophenol & $\begin{array}{c}5.7 \\
\text { INCIN }\end{array}$ & & Incineration \\
\hline U050-Chrysene & Chrysene & 8.2 & & Incineration \\
\hline \multirow[t]{6}{*}{ U051-Creosote } & $\begin{array}{l}\text { Naphthalene } \\
\text { Pentachlorophenol }\end{array}$ & $\begin{array}{l}1.5 \\
7.4\end{array}$ & & $\begin{array}{l}\text { Incineration (organics); } \\
\text { stabilization (lead) }\end{array}$ \\
\hline & Phenanthrene & 1.5 & & \\
\hline & Pyrene & 1.5 & & \\
\hline & Toluene & 28.0 & & \\
\hline & Xylenes (total) & 33.0 & & \\
\hline & Lead & & 0.51 & \\
\hline U052-Cresols (cresylic acid) & o-Cresol & 5.6 & & Incineration \\
\hline
\end{tabular}




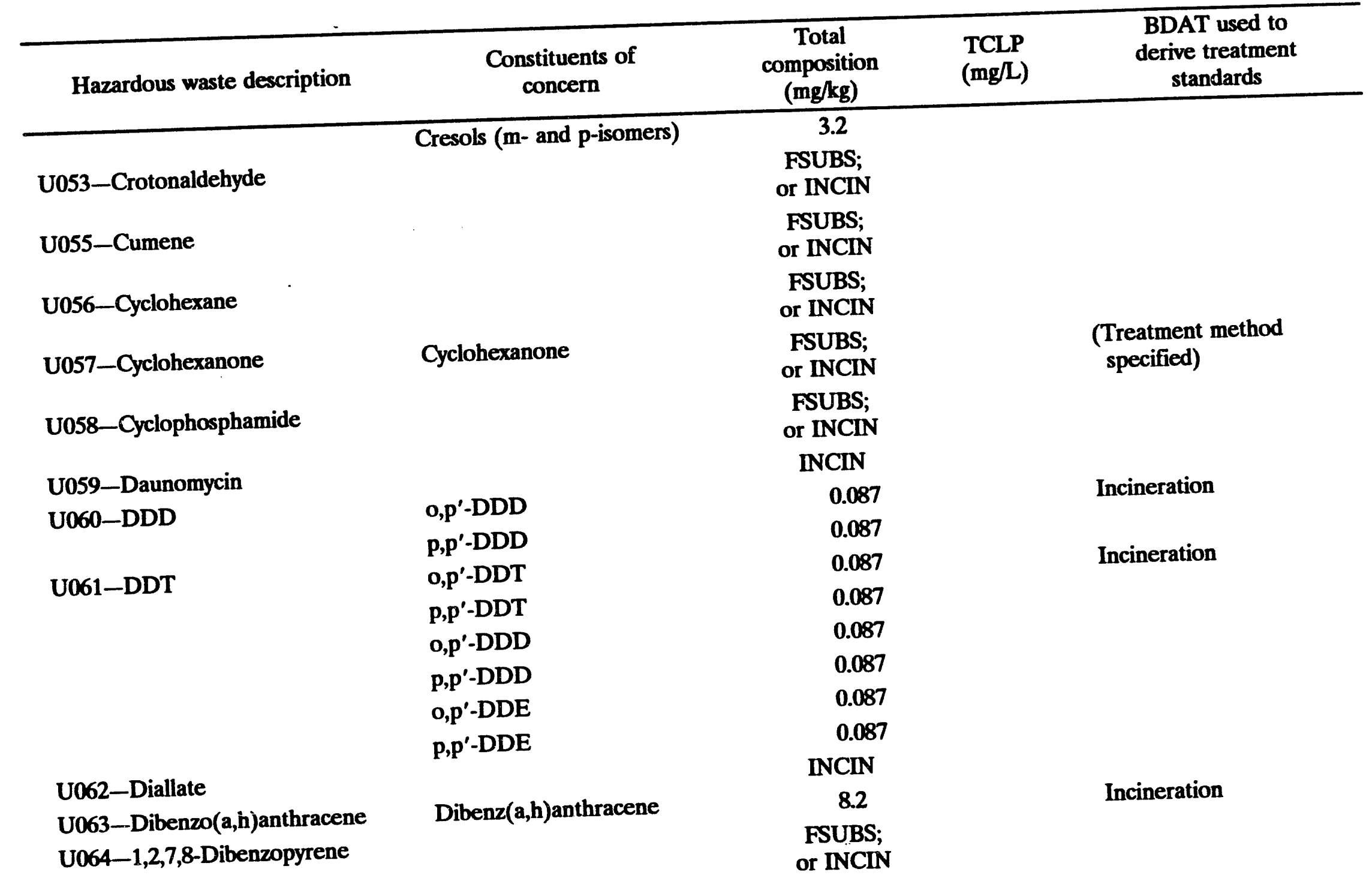




\begin{tabular}{|c|c|c|c|c|}
\hline Hazardous waste description & $\begin{array}{l}\text { Constituents of } \\
\text { concern }\end{array}$ & $\begin{array}{c}\text { Total } \\
\text { composition } \\
(\mathrm{mg} / \mathrm{kg})\end{array}$ & $\begin{array}{l}\text { TCLP } \\
(\mathrm{mg} / \mathrm{L})\end{array}$ & $\begin{array}{c}\text { BDAT used to } \\
\text { derive treatment } \\
\text { standards }\end{array}$ \\
\hline $\begin{array}{l}\text { U066-1,2-Dibromo-3- } \\
\text { chloropropane }\end{array}$ & $\begin{array}{l}\text { 1,2-Dibromo-3- } \\
\text { chloropropane }\end{array}$ & 15.0 & & Incineration \\
\hline U067-Ethylene dibromide & 1,2-Dibromoethane & 15.0 & & Incineration \\
\hline U068-Dibromomethane & Dibromomethane & 15.0 & & Incineration \\
\hline U069-Dibutyl phthalate & Di-n-butyl phthalate & 28.0 & & Rotary kiln incineration \\
\hline U070-o-Dichlorobenzene & o-Dichlorobenzene & 6.2 & & Incineration \\
\hline U071-m-Dichlorobenzene & m-Dichlorobenzene & 6.2 & & Incineration \\
\hline U072-p-Dichlorobenzene & p-Dichlorobenzene & 6.2 & & Incineration \\
\hline U073-Dichlorobenzidine,3,3'- & & INCIN & & \\
\hline UD74-1,4-Dichloro-2-butene & cis-1,4-Dichloro-2-butene & INCIN & & \\
\hline & trans-1,4-Dichloro-2-butene & INCIN & & \\
\hline U075-Dichlorodifluoromethane & Dichlorodifluoromethane & 7.2 & & Incineration \\
\hline U076-1,1-Dichloroethane & 1,1-Dichloroethane & 7.2 & & Incineration \\
\hline U077-1,2-Dichloroethane & 1,2-Dichloroethane & 7.2 & & Incineration \\
\hline U078-1,1-Dichloroethylene & 1,1-Dichloroethylene & 33.0 & & Incineration \\
\hline U079-1,2-Dichlorethylene & trans-1,2-Dichloroethylene & 33.0 & & Incineration \\
\hline U080-Methylene chloride & Methylene chloride & 33.0 & & Incineration \\
\hline U081-2,4-Dichlorophenol & 2,4-Dichlorophenol & 14.0 & & Incineration \\
\hline U082-2,6-Dichlorophenol & 2,6-Dichlorophenol & 14.0 & & Incineration \\
\hline U083-1,2-Dichloropropane & 1,2-Dichloropropane & 18.0 & & Incineration \\
\hline \multirow{2}{*}{ U084-cis-1,3-Dichloropropene } & cis-1,3-Dichloropropene & 18.0 & & Incineration \\
\hline & trans-1,3-Dichloropropene & 18.0 & & \\
\hline U085-2,2'-Bioxirane & 1,2,3,4-Diepoxybutane & $\begin{array}{l}\text { FSUBS; } \\
\text { or INCIN }\end{array}$ & & \\
\hline
\end{tabular}




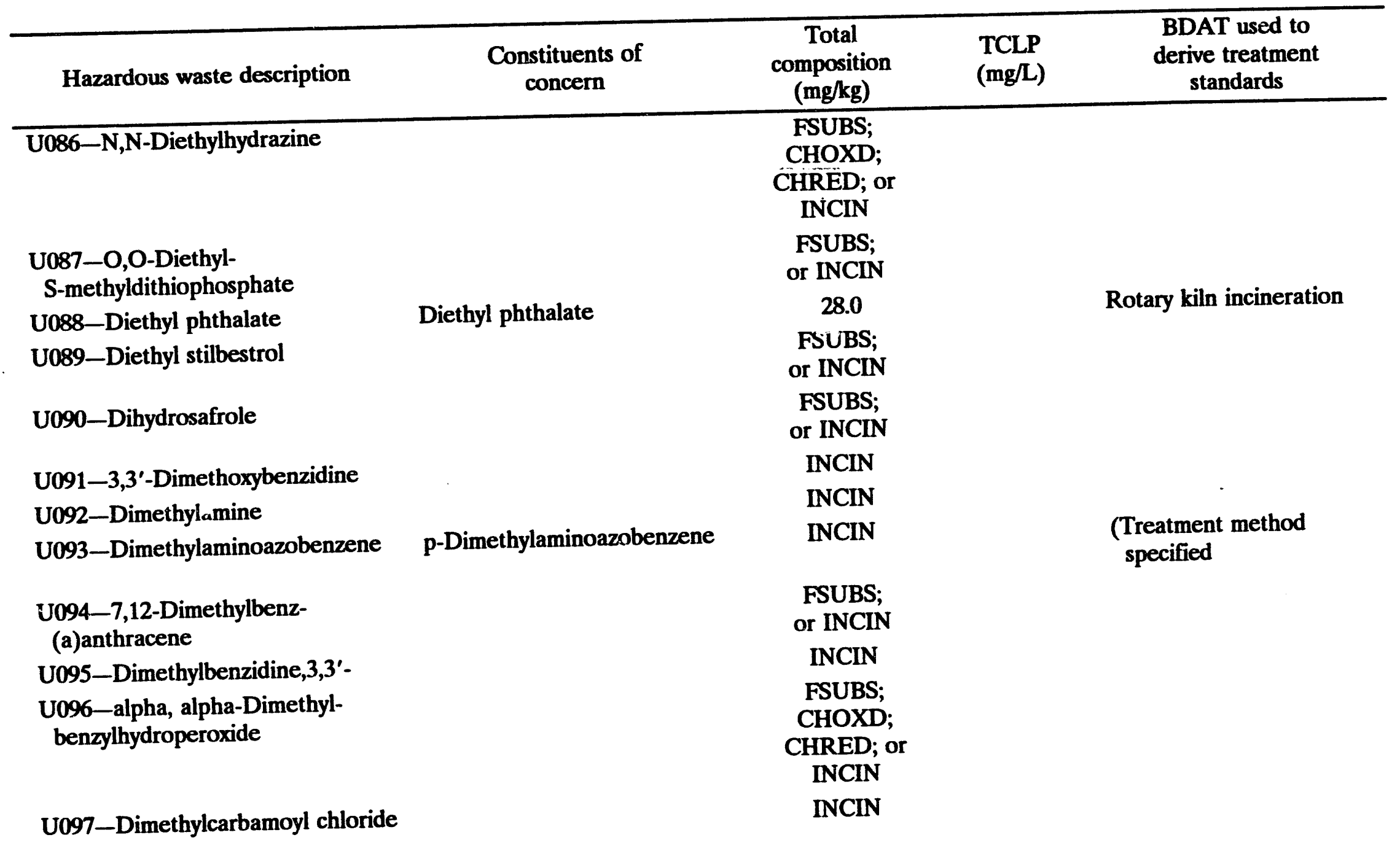




\begin{tabular}{|c|c|c|c|c|}
\hline Hazardous waste description & $\begin{array}{l}\text { Constituents of } \\
\text { concern }\end{array}$ & $\begin{array}{c}\text { Total } \\
\text { composition } \\
(\mathrm{mg} / \mathrm{kg})\end{array}$ & $\begin{array}{l}\text { TCLP } \\
(\mathrm{mg} / \mathrm{L})\end{array}$ & $\begin{array}{l}\text { BDAT used to } \\
\text { derive treatment } \\
\text { standards }\end{array}$ \\
\hline U098-Dimethylhydrazine,1,1- & & $\begin{array}{l}\text { FSUBS; } \\
\text { CHOXD; } \\
\text { CHRED; or } \\
\text { INCIN }\end{array}$ & & \\
\hline U099-Dimethylhydrazine,1,2- & & $\begin{array}{l}\text { FSUBS; } \\
\text { CHOXD; } \\
\text { CHRED; or } \\
\text { INCIN }\end{array}$ & & \\
\hline U101-2,4-Dimethyl phenol & 2,4-Dimethyl phenol & 14.0 & & Incineration \\
\hline U102-Dimethyl phthalate & Dimethyl phthalate & 28.0 & & Rotary kiln incineration \\
\hline U103-Dimethyl sulfate & & $\begin{array}{l}\text { FSUBS; } \\
\text { CHOXD; } \\
\text { CHRED; or } \\
\text { INCIN }\end{array}$ & & \\
\hline U105-2,4-Dinitrotoluene & 2,4-Dinitrotoluene & 140.0 & & Incineration \\
\hline U106-2,6-Dinitrotoluene & 2,6-Dinitrotoluene & 28.0 & & Incineration \\
\hline U107-Di-n-octyl phthalate & Di-n-octyl phthalate & 28.0 & & Rotary kiln inciueration \\
\hline U108-1,4-Dioxane & 1,4-Dioxane & 170.0 & & $\begin{array}{l}\text { Incineration or fuel } \\
\text { substitution }\end{array}$ \\
\hline U109-1,2-Diphenylhydrazine & & $\begin{array}{l}\text { FSUBS; } \\
\text { CHOXD; } \\
\text { CHRED; or } \\
\text { INCIN }\end{array}$ & & \\
\hline U110-Dipropylamine & & INCIN & & \\
\hline U111-Di-n-propylnitrosoamine & Di-n-propylnitrosoamine & 14.0 & & Incineration \\
\hline U112-Ethyl acetate & Ethyl acetate & 33.0 & & Incineration \\
\hline
\end{tabular}




\begin{tabular}{|c|c|c|c|c|}
\hline Hazardous waste description & $\begin{array}{l}\text { Constituents of } \\
\text { concern }\end{array}$ & $\begin{array}{c}\text { Total } \\
\text { composition } \\
(\mathrm{ng} / \mathrm{kg})\end{array}$ & $\begin{array}{l}\text { TCLP } \\
(\mathrm{mg} / \mathrm{L})\end{array}$ & $\begin{array}{l}\text { BDAT used to } \\
\text { derive treatment } \\
\text { standards }\end{array}$ \\
\hline U113-Eıhyl acrylate & & $\begin{array}{l}\text { FSUBS; } \\
\text { or INCIN }\end{array}$ & & \\
\hline $\begin{array}{l}\text { U114-Ethylene bis-dithiocarbamic } \\
\text { acid }\end{array}$ & & INCIN & & \\
\hline U115-Ethylene oxide & & $\begin{array}{l}\text { CHOXD; } \\
\text { or INCIN }\end{array}$ & & \\
\hline U116-Ethylene thiourea & & INCIN & & \\
\hline U117-Ethyl ether & Ethyl ether & 160.0 & & Incineration \\
\hline $\begin{array}{l}\text { U118-Ethylmethacrylatt } \\
\text { U119-Ethvl methane sultonate }\end{array}$ & Ethyl methacrylate & 160.0 & & Incineration \\
\hline $\begin{array}{l}\text { U119-Ethyl methane sultonate } \\
\text { U120-Fluoranthene }\end{array}$ & Fluoranthene & INCIN & & Incineration \\
\hline $\begin{array}{l}\text { U120-Fluoranthene } \\
\text { U121-Fluorotrichloromethane }\end{array}$ & $\begin{array}{l}\text { Fluoranthene } \\
\text { Trichloromonofluoromethane }\end{array}$ & $\begin{array}{r}8.2 \\
33.0\end{array}$ & & $\begin{array}{l}\text { Incineration } \\
\text { Incineration }\end{array}$ \\
\hline U122-Formaldehyde & & $\begin{array}{l}\text { FSUBS; } \\
\text { or INCIN }\end{array}$ & & \\
\hline U123-Formic acid & & $\begin{array}{l}\text { FSUBS; } \\
\text { or INCIN }\end{array}$ & & \\
\hline U124-Furan & & $\begin{array}{l}\text { FSUBS; } \\
\text { or INCIN }\end{array}$ & & \\
\hline U125-Furfural & & $\begin{array}{l}\text { FSUBS; } \\
\text { or INCIN }\end{array}$ & & \\
\hline U126-Glycidylaldehyde & & $\begin{array}{l}\text { FSUBS; } \\
\text { or INCIN }\end{array}$ & & \\
\hline U127-Hexachlorobenzene & Hexachlorobenzene & 37.0 & & Incineration \\
\hline U128-Hexachlorobutadiene & Hexachlorobutadiene & 28.0 & & Incineration \\
\hline U129-Lindane & alpha-BHC & 0.66 & & Incineration \\
\hline
\end{tabular}




\begin{tabular}{|c|c|c|c|c|}
\hline Hazardous waste description & $\begin{array}{l}\text { Constituents of } \\
\text { concern }\end{array}$ & $\begin{array}{c}\text { Total } \\
\text { composition } \\
(\mathrm{mg} / \mathrm{kg})\end{array}$ & $\begin{array}{l}\text { TCl P } \\
(\mathrm{mg} / \mathrm{L})\end{array}$ & $\begin{array}{l}\text { BDAT used to } \\
\text { derive treatment } \\
\text { standards }\end{array}$ \\
\hline & beta-BHC & 0.66 & & \\
\hline & delta-BHC & 0.66 & & \\
\hline U130-Hexachlorocyclopentadiene & gamma-BHC (Lindane) & 0.66 & & \\
\hline $\begin{array}{l}\text { U130-Hexachlorocyclopentadiene } \\
\text { U131-Hexachloroethune }\end{array}$ & Hexachlorocyclopentadiene & 3.6 & & Incineration \\
\hline & Hexachloroethane & 28.0 & & Incineration \\
\hline $\begin{array}{l}\text { U132-Hexachlorophene } \\
\text { U133-Hydrazine }\end{array}$ & & $\begin{array}{l}\text { INCIN } \\
\text { FSUBS; } \\
\text { CHOXD; } \\
\text { CHRED; or } \\
\text { INCIN }\end{array}$ & & \\
\hline U134-Hydrogen fluoride & Fluoride & $\begin{array}{l}\text { ADGAS fb } \\
\text { NEUTR; } \\
\text { or NEUTR }\end{array}$ & & $\begin{array}{l}\text { (Treatment method } \\
\text { specified) }\end{array}$ \\
\hline U135-Hydrogen sulfide & & $\begin{array}{l}\text { CHOXD; } \\
\text { CHRED; } \\
\text { or INCIN }\end{array}$ & & \\
\hline U136-Cacodylic acid & Arsenic & & 5.6 & Vitrification \\
\hline U137-Indeno(1,2,3-c,d)pyrene & Indeno(1,2,3-c,d)pyrene & 8.2 & & Incineration \\
\hline U138-Iodomethane & Iodomethane & 65.0 & & Incineration \\
\hline U140-Isobutanol & Isobutyl alcohol & 170.0 & & Incineration \\
\hline U141-Isosafrole & Isosafrole & 2.6 & & Incineration \\
\hline U142-Kepone & Kepone & 0.13 & & Incineration \\
\hline U143-Lasiocarpine & & INCIN & & \\
\hline U144-Lead acetate & Lead & & 0.51 & $\begin{array}{l}\text { Incineration followed by } \\
\text { stabilization }\end{array}$ \\
\hline
\end{tabular}




\begin{tabular}{|c|c|c|c|c|}
\hline Hazardous waste description & $\begin{array}{l}\text { Constituents of } \\
\text { concern }\end{array}$ & $\begin{array}{c}\text { Total } \\
\text { composition } \\
(\mathrm{mg} / \mathrm{kg})\end{array}$ & $\begin{array}{l}\text { TCLP } \\
(\mathrm{mg} / \mathrm{L})\end{array}$ & $\begin{array}{c}\text { BDAT used to } \\
\text { derive treatment } \\
\text { standards }\end{array}$ \\
\hline U145-Lead phosphate & Lead & & 0.51 & $\begin{array}{l}\text { Incineration followed by } \\
\text { stabilization }\end{array}$ \\
\hline U146-Lead subacetate & Lead & & 0.51 & $\begin{array}{l}\text { Incineration followed by } \\
\text { stabilization }\end{array}$ \\
\hline U147-Maleic anhydricie & & $\begin{array}{l}\text { FSUBS; } \\
\text { or INCIN }\end{array}$ & & \\
\hline U148-Maleic hydrazide & & INCIN & & \\
\hline U149-Malononitrile & & INCIN & & \\
\hline U150-Melphalan & & INCIN & & \\
\hline $\begin{array}{l}\text { U151-Mercury (Low-mercury } \\
\text { subcategory }<260 \mathrm{mg} / \mathrm{kg} \text { ) }\end{array}$ & Mercury & & $\begin{array}{l}0.20 \\
0.025\end{array}$ & $\begin{array}{l}\text { Acid leaching, chemical } \\
\text { precipitation }\end{array}$ \\
\hline $\begin{array}{l}\text { U151-Mercury (High-mercury } \\
\text { subcategory } \geq 260 \mathrm{mg} / \mathrm{kg} \text { ) }\end{array}$ & Mercury & RMERC & & $\begin{array}{l}\text { (Treatment method } \\
\text { specified) }\end{array}$ \\
\hline $\begin{array}{l}\mathrm{U} 151 \text {-Mercury contaminated with } \\
\text { radioactive materials }\end{array}$ & & AMLGM & & \\
\hline U152-Methacrylonitrile & Methacrylonitrile & 84.0 & & Incineration \\
\hline U153-Methane thiol & & INCIN & & \\
\hline U154-Methanol & & $\begin{array}{l}\text { FSUBS; } \\
\text { or INCIN }\end{array}$ & & \\
\hline U155-Methapyrilene & Methapyrilene & 1.5 & & Incineration \\
\hline U156-Methyl chlorocarbonate & & INCIN & & \\
\hline U157-3-Methylcholanthrene & 3-Methylcholanthrene & 15.0 & & Incineration \\
\hline $\begin{array}{l}\text { U158-4,4'-Methylene-bis-( } 2 \text { - } \\
\text { chloroaniline) }\end{array}$ & $\begin{array}{l}\text { 4,4'-Methylene-bis- } \\
\text { (2-chloroaniline) }\end{array}$ & 35.0 & & Incineration \\
\hline U159-Methyl ethyl ketone & Methyl ethyl ketone & 36.0 & & Incineration \\
\hline
\end{tabular}




\begin{tabular}{|c|c|c|c|c|}
\hline Hazardous waste description & $\begin{array}{l}\text { Constituents of } \\
\text { concern }\end{array}$ & $\begin{array}{c}\text { Total } \\
\text { composition } \\
(\mathrm{mg} / \mathrm{kg})\end{array}$ & $\begin{array}{l}\text { TCLP } \\
(\mathrm{mg} / \mathrm{L})\end{array}$ & $\begin{array}{l}\text { BDAT used to } \\
\text { derive treatment } \\
\text { standards }\end{array}$ \\
\hline $\begin{array}{l}\text { U160-Methyl ethyl ketone } \\
\text { peroxide }\end{array}$ & & $\begin{array}{l}\text { FSUBS; } \\
\text { CHOXD; } \\
\text { CHRED; or } \\
\text { INCIN }\end{array}$ & & \\
\hline U161-Methyl isobutyl ketone & Methyl isobutyl ketone & $\mathbf{3 3 . 0}$ & & Incineration \\
\hline U162-Methyl methacrylate & Methyl methacrylate & 160.0 & & Incineration \\
\hline $\begin{array}{l}\text { U163-N-Methyl-N'nitro-N- } \\
\text { nitrosoguanidine }\end{array}$ & & INCIN & & \\
\hline U165-Naphthalene & Naphthalene & $\begin{array}{c}\text { INCIN } \\
3.1\end{array}$ & & Incineration \\
\hline U166-1,4-Naphthaquinone & & $\begin{array}{l}\text { FSUBS; } \\
\text { or INCIN }\end{array}$ & & \\
\hline U167-1-Naphthylamine & & INCIN & & \\
\hline U168-2-Napthylamine & 2-Napthylamine & INCIN & & $\begin{array}{l}\text { (Treatment method } \\
\text { specified) }\end{array}$ \\
\hline U169-Nitrobenzene & Nitrobenzene & 14.0 & & Incineration \\
\hline U170-p-Nitrophenol & 4-Nitrophenol & 29.0 & & Incineration \\
\hline U171-Nitropropane,2- & & INCIN & & \\
\hline U172-N-Nitroso-di-n-butylamine & N-Nitroso-di-n-butylamine & 17.0 & & Incineration \\
\hline U173-N-Nitro-di-N-ethanolamine & & INCIN & & \\
\hline U174-N-Nitrosodiethylamine & N-Nitrosodiethylamine & 28.0 & & Incineration \\
\hline U176-N-Nitroso-N-ethylurea & & INCIN & & \\
\hline U177-N-Nitroso-N-methylurea & & INCIN & & \\
\hline $\begin{array}{l}\text { U178-N-Nitroso-N- } \\
\text { methylurethane }\end{array}$ & & INCIN & & \\
\hline
\end{tabular}




\begin{tabular}{|c|c|c|c|c|}
\hline Hazardous waste description & $\begin{array}{l}\text { Constituents of } \\
\text { concern }\end{array}$ & $\begin{array}{c}\text { Total } \\
\text { composition } \\
(\mathrm{mg} / \mathrm{kg}) \\
\end{array}$ & $\begin{array}{l}\text { TCLP } \\
(\mathrm{mg} / \mathrm{L})\end{array}$ & $\begin{array}{c}\text { BDAT used to } \\
\text { derive treatment } \\
\text { standards }\end{array}$ \\
\hline U179-N-Nitrosopiperidine & N-Nitrosopiperidine & 35.0 & & Incineration \\
\hline U180-N-Nitrosopyrrolidine & N-Nitrosopyrrolidine & 35.0 & & Incineration \\
\hline U181-5-Nitro-o-toluidine & 5-Nitro-o-toluidine & 28.0 & & Incineration \\
\hline U182-Paraldehyde & & $\begin{array}{l}\text { FSUBS; } \\
\text { or INCIN }\end{array}$ & & \\
\hline U183-Pentachlorobenzene & Pentachlorobenzene & 37.0 & & Incineration \\
\hline U184-Pentachloroethane & & INCIN & & \\
\hline U185-Pentachloronitrobenzene & Pentachloronitrobenzene & 4.8 & & Incineration \\
\hline U186-1,3-Pentadiene & & $\begin{array}{l}\text { FSUBS; } \\
\text { or INCIN }\end{array}$ & & \\
\hline U187-Phenacetin & Phenacetin & 16.0 & & Incineration \\
\hline U188-Phenol & Phenol & 6.2 & & Incineration \\
\hline U189-Phosphorus sulfide & & $\begin{array}{l}\text { CHOXD; } \\
\text { CHRED; } \\
\text { or INCIN }\end{array}$ & & \\
\hline U190-Phthalic anhydride & $\begin{array}{l}\text { Phthalic anhydride (measured } \\
\text { as phthalic acid) }\end{array}$ & 28.0 & & Rotary kiln incineration \\
\hline U191-2-Picoline & & INCIN & & \\
\hline U192-Pronamide & Pronamide & 1.5 & & Incineration \\
\hline U193-1,3-Propane sultone & & INCIN & & \\
\hline U194-N-Propylamine & & INCIN & & \\
\hline U196-Pyridine & Pyridine & 16.0 & & Incineration \\
\hline U197-p-Benzoquinone & & $\begin{array}{l}\text { FSUBS; } \\
\text { or INCIN }\end{array}$ & & \\
\hline U200-Reserpine & & INCIN & & \\
\hline
\end{tabular}




\begin{tabular}{|c|c|c|c|c|}
\hline Hazardous waste description & $\begin{array}{l}\text { Constituents of } \\
\text { concern }\end{array}$ & $\begin{array}{c}\text { Total } \\
\text { composition } \\
(\mathrm{mg} / \mathrm{kg})\end{array}$ & $\begin{array}{c}\text { TCLP } \\
(\mathrm{mg} / \mathrm{L})\end{array}$ & $\begin{array}{l}\text { BDAT used to } \\
\text { derive treatment } \\
\text { standards }\end{array}$ \\
\hline U201-Resorcinol & Resorcinol & $\begin{array}{l}\text { FSUBS; } \\
\text { or INCIN }\end{array}$ & & \\
\hline U202-Saccharin and salts & & INCIN & & \\
\hline U203-Safrole & Safrole & 22.0 & & Incineration \\
\hline U204-Selenious acid & Selenium & & 5.7 & Stabilization \\
\hline U205-Selenium disulfide & Selenium & & 5.7 & Stabilization \\
\hline U206-Streptozotocin & & INCIN & & \\
\hline U207-1,2,4,5-Tetrachlorobenzene & 1,2,4,5-Tetrachlorobenzene & 19.0 & & Incineration \\
\hline U208-1,1,1,2-Tetrachloroethane & 1,1,1,2-Tetrachloroethane & 42.0 & & Incineration \\
\hline U209-1,1,2,2-Tetrachloroethane & 1,1,2,2-Tetrachloroethane & 42.0 & & Incineration \\
\hline U210-Tetrachloroethylene & Tetrachloroethylene & 5.6 & & Incineration \\
\hline U211-Carbon tetrachloride & Carbon tetrachloride & 5.6 & & Incineration \\
\hline U213-Tetrahydrofuran & & $\begin{array}{l}\text { FSUBS; } \\
\text { or INCIN }\end{array}$ & & \\
\hline U214-Thallium (I) acetate & Thallium & $\begin{array}{l}\text { RTHRM; } \\
\text { or STABL }\end{array}$ & & $\begin{array}{l}\text { (Treatment method } \\
\text { specified) }\end{array}$ \\
\hline U215-Thallium (I) carbonate & Thallium & $\begin{array}{l}\text { RTHRM; } \\
\text { or STABL }\end{array}$ & & $\begin{array}{l}\text { (Treatment method } \\
\text { specified) }\end{array}$ \\
\hline U216-Thallium (I) chloride & Thallium & $\begin{array}{l}\text { RTHRM; } \\
\text { or STABL }\end{array}$ & & $\begin{array}{l}\text { (Treatment method } \\
\text { specified) }\end{array}$ \\
\hline U217-Thallium (I) nitrate & Thallium & $\begin{array}{l}\text { RTHRM; } \\
\text { or STABL }\end{array}$ & & $\begin{array}{l}\text { (Treatment method } \\
\text { specified) }\end{array}$ \\
\hline U218-Thioacetamide & & INCIN & & \\
\hline U219-Thiourea & & INCIN & & \\
\hline U220-Toluene & Toluene & 28.0 & & Incineration \\
\hline
\end{tabular}




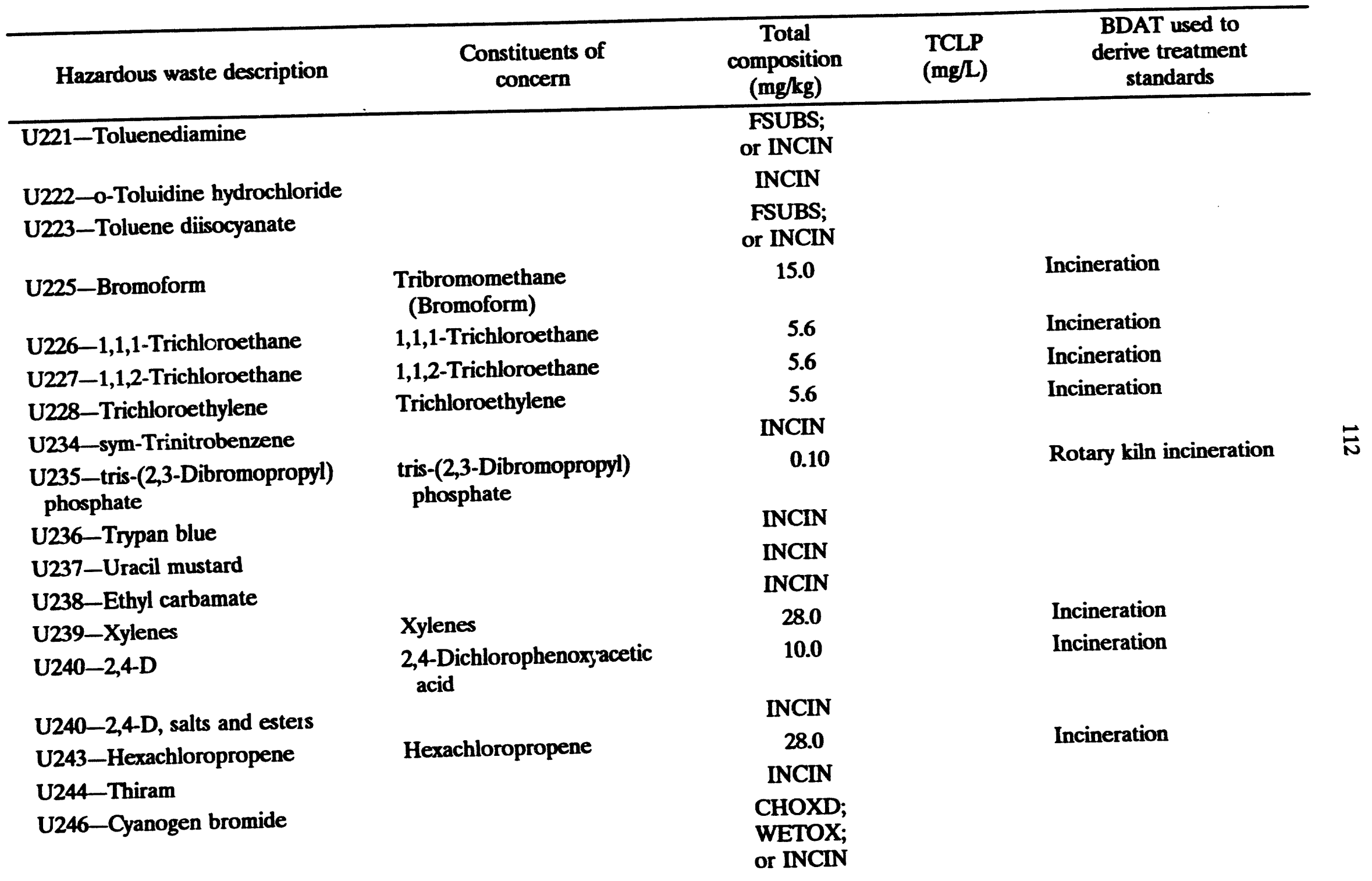




\begin{tabular}{|c|c|c|c|c|}
\hline Hazardous waste description & $\begin{array}{l}\text { Constituents of } \\
\text { concern }\end{array}$ & $\begin{array}{c}\text { Total } \\
\text { composition } \\
(\mathrm{mg} / \mathrm{kg})\end{array}$ & $\begin{array}{l}\text { TCLP } \\
(\mathrm{mg} / \mathrm{L})\end{array}$ & $\begin{array}{c}\text { BDAT used to } \\
\text { derive treatment } \\
\text { standards } \\
\end{array}$ \\
\hline U247-Methoxychlor & Methoxychlor & 0.18 & & Incineration \\
\hline $\begin{array}{l}\text { U248-Warfarin, when present at } \\
\text { concentrations of } 0.3 \% \text { or less }\end{array}$ & & $\begin{array}{l}\text { FSUBS; } \\
\text { or INCIN }\end{array}$ & & \\
\hline $\begin{array}{l}\text { U249-Zinc phosphide, when } \\
\text { present at concentrations of } 10 \% \\
\text { or less }\end{array}$ & & $\begin{array}{l}\text { CHOXD; } \\
\text { CHRED; } \\
\text { or INCIN }\end{array}$ & & \\
\hline U328-o-Toluidine & & $\begin{array}{l}\text { INCIN } \\
\text { or thermal } \\
\text { destruction }\end{array}$ & & \\
\hline U353-p-Toluidine & & $\begin{array}{l}\text { INCIN } \\
\text { or thermal } \\
\text { destruction }\end{array}$ & & \\
\hline U359-2-ethoxy-ethanol & & $\begin{array}{l}\text { FSUBS; } \\
\text { or INCIN }\end{array}$ & & \\
\hline
\end{tabular}

${ }^{a}$ Also applies to D001 and D002 wastes prohibited under 40 CFR 268.37. 
Appendix B.

TECHNOLOGY CODES USED IN APPENDIX A 


\title{
Appendix B. TECHNOLOGY CODES AND DESCRIPTION OF TECHNOLOGY-BASED STANDARDS
}

\author{
Technology \\ code \\ Description of technology-based standards
ADGAS: Venting of compressed gases into an absorbing or reacting media (i.e., solid or liquid)-venting can be accomplished through physical release utilizing valves/piping, physical penetration of the container, and/or penetration through detonation.

AMLGM: Amalgamation of liquid, elemental mercury contaminated with radioactive materials utilizing inorganic reagents such as copper, zinc, nickel, gold, and sulfur that result in a nonliquid, semisolid amalgam and thereby reducing potential emissions of elemental mercury vapors to the air.

BIODG: Biodegradation of organics or nonmetallic inorganics (i.e., degradable inorganics that contain the elements of phosphorus, nitrogen, and sulfur) in units operated under either aerobic or anaerobic conditions such that a surrogate compound or indicator parameter has been substantially reduced in concentration in the residuals (e.g., total organic carbon can often be used as an indicator parameter for the biodegradation of many organic constituents that cannot be directly analyzed in wastewater residues).

CARBN: Carbon adsorption (granulated or powered) of nonmetallic inorganics, organo-metallics, and/or organic constituents, operated such that a surrogate compound or indicator parameter has not undergone breakthrough (e.g., total organic carbon can often be used as an indicator parameter for the adsorption of many organic constituents that cannot be directly analyzed in wastewater residues). Breakthrough occurs when the carbon has become saturated with the constituent (or indicator parameter) and substantial change in adsorption rate associated with that constituent occurs.

CHOXD: Chemical or electrolytic oxidation utilizing the following oxidation reagents (or waste reagents) or combinations of reagents: (1) hypochlorite (e.g., bleach); (2) chlorine; (3) chlorine dioxide; (4) ozone or uv (ultraviolet light) assisted ozone; (5) peroxides; (6) persulfates; (7) perchlorates; (8) permagantes; and/or (9) other oxidizing reagents of equivalent efficiency, performed in units operated such that a surrogate compound or indicator parameter has been substantially reduced in concentration in the residuals (e.g., total organic carbon can often be used as an indicator parameter for the oxidation of many organic constituents that cannot be directly analyzed in wastewater residues). Chemical oxidation specifically includes what is commonly referred to as alkaline chlorination. 
Technology code

Description of technology-based standards

CHRED: Chemical reduction utilizing the following reducing reagents (or waste reagents) or combinations of reagents: (1) sulfur dioxide; (2) sodium, potassium, or alkali salts or sulfites, bisulfites, metabisulfites, and polyethylene glycols (e.g., NaPEG and KPEG); (3) sodium hydrosulfide; (4) ferrous salts; and/or (5) other reducing reagents of equivalent efficiency, performed in units operated such that a surrogate compound or indicator parameter has been substantially reduced in concentration in the residuals (e.g., total organic halogens can often be used as an indicator parameter for the reduction of many halogenated organic constituents that cannot be directly analyzed in wastewater residues). Chemical reduction is commonly used for the reduction of hexavalent chromium to the trivalent state.

DEACT: Deactivation to remove the hazardous characteristics of a waste because of its ignitability, corrosivity, and/or reactivity.

FSUBS: $\quad$ Fuel substitution in units operated in accordance with applicable technical operating requirement.

HLVIT: Vitrification of high-level mixed radioactive wastes in units in compliance with all applicable radioactive protection requirements under control of the Nuclear Regulatory Commission.

IMERC: Incineration of wastes containing organics and mercury in units operated in accordance with the technical operating requirements of 40 CFR Part 264, Subpart O, and Part 265, Subpart O. All wastewater and nonwastewaster residues derived from this process must then comply with the corresponding treatment standards per waste code with consideration of any applicable subcategories (e.g., high and low mercury subcategories).

INCIN: Incineration in units operated in accordance with the technical operating requirements of 40 CFR Part 264, Subpart O, and Part 265, Subpart 0.

LLEXT: Liquid-liquid extraction (often referred to as solvent extraction) of organics from liquid wastes into an immiscible solvent for which the hazardous constituents have a greater solvent affinity, resulting in an extract high in organics that must undergo either incineration, reuse as a fuel, or other recovery/reuse and a raffinate (extracted liquid waste) proportionately low in organics that must undergo further treatment as specified in the standard.

MACRO: Macroencapsulation with surface coating materials such as polymeric organics (e.g., resins and plastics) or with a jacket of inert inorganic materials to substantially reduce surface exposure to potential leaching media. Macroencapsulation specifically does not include any material that would be classified as a tank or container according to 40 CFR 260.10. 


\section{Technology} code

Description of technology-based standards

NEUTR: Neutralization with the following reagents (or waste reagents) or combinations of reagents: (1) acids; (2) bases; or (3) water (including wastewaters) resulting in a $\mathrm{pH}>2$ but $<12.5$ as measured in the aqueous residuals.

NLDBR: No land disposal based on recycling.

PRECP: Chemical precipitation of metals and other inorganics as insoluble precipitates of oxides, hydroxides, carbonates, sulfides, chlorides, fluorides, or phosphates. The following reagents (or waste reagents) are typically used alone or in combination: (1) lime (i.e., containing oxides and/or hydroxides of calcium and/or magnesium); (2) caustic (i.e., sodium and/or potassium hydroxides); (3) soda ash (i.e., sodium carbonate); (4) sodium sulfide; (5) ferric sulfate or ferric chloride; (6) alum; or (7) sodium sulfate. Additional flocculating, coagulation, or similar reagents/processes that enhance sludge dewatering characteristics are not precluded from use.

RBERY: Thermal recovery of beryllium.

RCGAS: Recovery/reuse of compressed gases, including techniques such as reprocessing of the gases for reuse/resale; filtering/adsorption of impurities; remixing for direct reuse and resale; and use of the gas as a fuel source.

RCORR: Recovery of acids or bases utilizing one or more of the following recovery technologies: (1) distillation (i.e., thermal concentration); (2) ion exchange; (3) resin or solid adsorption; (4) reverse osmosis; and/or (5) incineration for the recovery of acid-Note: this does not preclude the use of other physical separation or concentration techniques such as decantation, filtration (including ultrafiltration), and centrifugation, when used in conjunction with the above listed recovery technologies.

RLEAD: Thermal recovery of lead in secondary lead smelters.

RMERC: Retorting or roasting in a thermal processing unit capable of volatilizing mercury and subsequently condensing the volatilized mercury for recovery. The retorting or roasting unit (or facility) must be subject to one or more of the following: (a) a National Emissions Standard for Hazardous Air Pollutants (NESHAP) for mercury; (b) a best available control technology (BACT) or a lowest achievable emission rate (LAER) standard for mercury imposed pursuant to a Prevention of Significant Deterioration (PSD) permit; or (c) a state permit that establishes emission limitations (within meaning of Sect. 302 of the Clean Air Act) for mercury. All wastewater and nonwastewater residues derived from this process must then comply with the corresponding treatment standards per waste code with consideration of any applicable subcategories (e.g., high or low mercury subcategories). 
Technology code

Description of technology-based standards

RMETL: Recovery of metals or inorganics utilizing one or more of the following direct physical/removal technologies: (1) ion exchange; (2) resin or solid (i.e., zeolites) adsorption; (3) reverse osmosis; (4) chelation/solvent extraction; (5) freeze crystallization; (6) ultrafiltration and/or (7) simple precipitation (i.e., crystallization)-Note: This does not preclude the use of other physical phase separation or concentration techniques such as decantation, filtration (including ultrafiltration), and centrifugation, when used in conjunction with the above-listed recovery technologies.

RORGS: Recovery of organics utilizing one or more of the following technologies: (1) distillation; (2) thin-film evaporation; (3) steam stripping; (4) carbon adsorption; (5) critical fluid extraction; (6) liquid-liquid extraction; (7) precipitation/crystallization (including freeze crystalliz ' ${ }^{\circ}$ ); ; or (8) chemical phase separation techniques (i.e., addition of w. ts, bases, demulsifiers, or similar chemicals)-Note: This does not precibue the use of other physical phase separation techniques such as a decantation, filtration (including ultrafiltration), and centrifugation, when used in conjunction with the above-listed recovery technologies.

RTHRM: Thermal recovery of metal or inorganics from nonwastewaters in units identified as industrial furnaces according to 40 CFR 260.10 (1), (6), (7), (11), and (12) under the definition of "industrial furnaces."

STABL: Stabilization with the following reagents (or waste reagents) or combinations of reagents: (1) Portland cement; or (2) lime/pozzolans (e.g., fly ash and cement kiln dust)-this does not preclude the addition of reagents (e.g., iron salts, silicates, and clays) designed to enhance the set/cure time and/or compressive strength or to overall reduce the leachability of the metal or inorganic.

SSTRP: $\quad$ Steam stripping of organics from liquid wastes utilizing direct application of steam to the wastes operated such that liquid and vapor flow rates, as well as temperature and pressure ranges, have been optimized, monitored, and maintained. These operating parameters are dependent upon the design parameters of the unit such as the number of separation stages and the internal column design. Thus, resulting in a condensed extract high in organics that must undergo either incineration, reuse as a fuel, or other recovery/reuse and an extracted wastewater that must undergo further treatment as specified in the standard.

WETOX: Wet air oxidation performed in units operated such that a surrogate compound or indicator parameter has been substantially reduced in concentration in the residuals (e.g., total organic carbon can often be used as an indictor parameter for the oxidation of many organic constituents that cannot be directly analyzed in wastewater residues). 
Technology code

WTRRX: Controlled reaction with water for highly reactive inorganic or organic chemicals with precautionary controls for protection of workers form potential violent reactions as well as precautionary controls for potential emissions of toxic/ignitable levels of gases released during the reaction. 
Appendix C.

TREATMENT STANDARDS FOR DEBRIS 


\title{
Appendix C. ALTERNATTVE TREATMENT STANDARDS FOR HAZARDOUS DEBRIS ${ }^{1}$
}

Technology description

\author{
Performance and/or design \\ and operating standard
}

Contaminant

restrictions ${ }^{2}$

A. Extraction Technologies:

1. Physical Extraction

a. Abrasive Blasting: Removal of contaminated debris surface layers using water and/or air pressure to propel a solid media (e.g., steel shot, aluminum oxide grit, plastic beads).

b. Scarification, Grinding, and Planing: Process utilizing striking piston heads, saws, or rotating grinding wheels such that contaminated debris surface layers are removed.

c. Spalling: Drilling or chipping holes at appropriate locations and depth in the contaminated debris surface and applying a tool that exerts a force on the sides of those holes such that the surface layer is removed. The surface layer removed remains hazardous debris subject to the debris treatment standards.

d. Vibratory Finishing: Process utilizing scrubbing media, flushing fluid, and oscillating energy such that hazardous contaminants or contaminated debris surface layers are removed. ${ }^{4}$

All Debris: None.

Glass, Metal, Plastic, Rubber. Treatment to a clean debris surface. $^{3}$

Brick, Cloth, Concrete, Paper,

Pavement, Rock, Wood:

Removal of at least $0.6 \mathrm{~cm}$ of the surface layer; and treatment to a clean debris surface. ${ }^{3}$

Same as above.

Same as above.

Same as above.

Same as above. 
Technology description

e High Pressure Steam and

e. High Pressure Steam and Water Sprays: Application of water or steam sprays of sufficient temperature, pressure, residence time, agitation, surfactants, and detergents to remove hazardous contaminants from debris surfaces or to remove contaminated debris surface layers.

2. Chemical Extraction

a. Water Washing and Spraying: Application of water sprays or water baths of sufficient temperature, pressure, residence time, agitation, surfactants, acids, bases, and detergents to remove hazardous contaminants from debris surfaces and surface pores or to remove contaminated debris surface layers.

b. Liquid Phase Solvent Extraction: Removal of hazardous contaminants from debris surfaces and surface pores by applying a nonaqueous liquid or liquid solution which causes the hazardous contaminants to enter the liquid phase and be flushed away from the debris along with the liquid or liquid solution while using appropriate agitation, temperature, and residence time. ${ }^{4}$
All Debris: Treatment to a clean debris surface. ${ }^{3}$ Brick, Cloth, Concrete, Paper, Pavement, Rock, Wood: Debris must be no more than $1.2 \mathrm{~cm}$ (1/2 in.) in one dimension (i.e., thickness limit,' except that this thickness limit may be waived under an "Equivalent Technology" approval under 8268.42(b); ${ }^{6}$ debris surfaces must be in contact with water solution for at least $15 \mathrm{~min}$.

Same as above.
Contaminant restrictions ${ }^{2}$

Same as above.

\author{
Brick, Cloth, \\ Concrete, \\ Paper, Pavement, \\ Rock, Wood: \\ Contaminant must be \\ soluble to at least \\ $5 \%$ by weight in \\ water solution or $5 \%$ \\ by weight in \\ emulsion; if debris is \\ contaminated with a \\ dioxin-listed waste, \\ an "Equivalent \\ Technology" \\ approval under \\ \$268.42(b) must be \\ obtained.
}

\footnotetext{
Brick, Cloth, Concrete, Paper, Pavement, Rock, Wood: Same as above, except that contaminant must be soluble to at least $5 \%$ by weight in the solvent.
} 


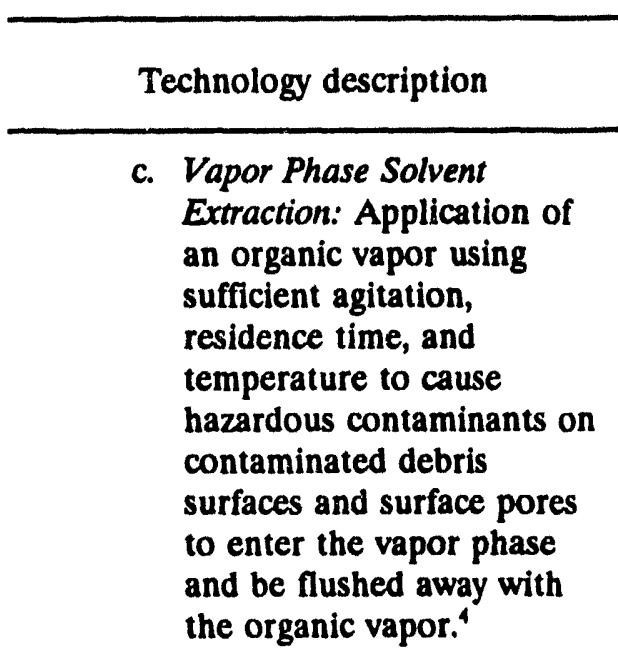

3. Thermal Extraction

a. High Temperature Metals Recovery: Application of sufficient heat, residence time, mixing, fluxing agents, and/or carbon in a smelting, melting, or refining furnace to separate metals from debris.

b. Thermal Desorption: Heating in an enclosed chamber under either oxidizing or nonoxidizing atmospheres at sufficient temperature and residence time to vaporize hazardous contaminants from contaminated surfaces and surface pores and to remove the contaminants from the heating chamber in a gaseous exhaust gas."

\section{Performance and/or design Contaminant and operating standard restrictions ${ }^{2}$}

Same as above, except that

Same as above.

brick, cloth, concrete, paper, pavement, rock, and wood surfaces must be in contact with the organic vapor for at least $60 \mathrm{~min}$.

For refining furnaces, treated debris must be separated from treatment residuals using simple physical or mechanical means, ${ }^{8}$ and, prior to further treatment, such residuals must meet the waste-specific treatment standards for organic compounds in the waste contaminating the debris.

All Debris: Obtain an "Equivalent Technology" approval under \$268.42(b); treated debris must be separated from treatment residuals using simple physical or mechanical means, ${ }^{8}$ and, prior to further treatment, such residue must meet the wastespecific treatment standards for organic compounds in the waste contaminating the debris. Brick, Cloth, Concrete, Paper, Pavement, Rock, Wood: Debris must be no more than $10 \mathrm{~cm}$ (4 in.) in one dimension (i.e., thickness limit), ${ }^{5}$ except that this thickness limit may be waived under the "Equivalent Technology" approval.
Debris contaminated with a dioxin-listed waste: ${ }^{5}$ Obtain an "Equivalent Technology" approval under \$268.42(b). ${ }^{6}$

All Debris: Metals other than mercury. 
Technology description

B. Destruction Technologies:

1. Biological Destruction

(Biodegradation): Removal of hazardous contaminants from debris surfaces and surface pores in an aqueous solution and biodegration of organic or nonmetallic inorganic compounds (i.e., inorganics that contain phosphorus, nitrogen, or sulfur) in units operated under either aerobic or anaerobic conditions.
2. Chemical Destruction

a. Chemical Oxidation: Chemical or electrolytic oxidation utilizing the following oxidation reagents (or waste reagents) or combination of reagents(1) hypochlorite (e.g., bleach); (2) chlorine;

(3) chlorine dioxide;

(4) ozone or uv (ultraviolet light) assisted ozone; (5) peroxides,

(6) persulfates;

(7) perchlorates;

(8) permanganates; and/or

(9) other oxidizing reagents of equivalent destruction efficiency. ${ }^{4}$ Chemical oxidation specifically includes what is referred to as alkaline chlorination. Performance and/or design
and operating standard

Contaminant
All Debris: Obtain an

"Equivalent Technology"

approval under $\$ 268.42(\mathrm{~b}) ;^{6}$

treated debris must be

separated from treatment

residuals using simple physical

or mechanical means, ${ }^{8}$ and,

prior to further treatment, such

residue must meet the waste-

specific treatment standards for

organic compounds in the

waste contaminating the debris.

Brick, Cloth, Concrete, Paper,

Pavement, Rock, Wood: Debris

must be no more than $1.2 \mathrm{~cm}$

$(1 / 2$ in.) in one dimension (i.e., thickness limit), except that this thickness limit may be waived under the "Equivalent

Technology" approval

All Debris: Obtain an "Equivalent Technology" approval under $\$ 268.42(b) ; 6$ treated debris must be separated from treatment residuals using simple physical or mechanical means, ${ }^{8}$ and, prior to further treatment, such residue must meet the wastespecific treatment standards for organic compounds in the waste contaminating the debris. Brick, Cloth, Concrete, Paper, Pavement, Rock, Wood: Debris must be no more than $1.2 \mathrm{~cm}$ $(1 / 2 \mathrm{in}$.) in one dimension (i.e., thickness limit), except that this thickness limit may be waived under the "Equivalent Technology" approval
All Debris: Metal contaminants.
All Debris: Metal contaminants. 


\begin{tabular}{|c|}
\hline Technology description \\
\hline $\begin{array}{l}\text { b. Chemical seduction: } \\
\text { Chemical reaction utilizing } \\
\text { the following reducing } \\
\text { reagents (or waste } \\
\text { reagents) or combination } \\
\text { of reagents: (1) sulfur } \\
\text { dioxice; (2) sodium, } \\
\text { potassium, or alkali salts } \\
\text { of sulfites, bisulfites, and } \\
\text { metabisulfites, and } \\
\text { polyethylene glycols (e.g., } \\
\text { NaPEG and KPEG); } \\
\text { (3) sodium hydrosulfide; } \\
\text { (4) ferrous salts; and/or } \\
\text { (5) other reducing reagents } \\
\text { of equivalent efficiency. }\end{array}$ \\
\hline
\end{tabular}

3. Thermal Destruction:

Treatment in an incinerator operating in accordance with Subpart O of Parts 264 or 265 of this chapter; a boiler or industrial furnace operating in accordance with Subpart $\mathrm{H}$ of Part 266 of this chapter, or other thermal treatment unit operated in accordance with Subpart X, Part 264, of this chapter, or Subpart $P$, Part 265, of this chapter, but excluding for purposes of these debris treatment standards Thermal Desorption Units.

C. Immobilization Technologies:

1. Macroencapsulation: Application of surface coating materials such as polymeric organics (e.g., resins and plastics) or use of a jacket of inert inorganic materials to substantially reduce surface exposure to potential leaching media.
Performance and/or design and operating standard

Same as above.

Contaminant restrictions ${ }^{2}$

Same as above.
Treated debris must be separated from treatment residuals using simple physical or mechanical means, ${ }^{8}$ and, prior to further treatment, such residue must meet the wastespecific treatment standards for organic compounds in the waste contaminating the debris.

Encapsulating material must completely encapsulate debris and be resistant to degradation by the debris and its contaminants and materials into which it may come into contact after placement (leachate, other waste, microbes).
Brick, Concrete, Glass, Metal, Pavement, Rock, Metal: Metals other than mercury, except that there are no metal restrictions for vitrification.

Debris contaminated with a diaxin-listed waste ${ }^{7}$ Obtain an "Equivalent Technology" approval under 8268.42(b), except that this requirement does not apply to vitrification.

None. 
Technology description

2. Microencapsulation: Stabilization of the debris with the following reagents (or waste reagents) such that the leachability of the hazardous contaminants is reduced: (1) Portland cement, or (2) lime/pozznlans (e.g., fly ash and cement kiln dust). Reagents (e.g., iron salts, silicates, and clays) may be added to enhance the set/cure time and/or compressive strength or to reduce the leachability of the hazardous constituents. ${ }^{\text {s }}$

3. Sealing: Application of an appropriate material which adheres tightly to the debris surface to avoid exposure of the surface to potential leaching media. When necessary to effectively seal the surface, sealing entails pretreatment of the debris surface to remove foreign matter and to clean and roughen the surface. Sealing materials include epoxy, silicone, and urethane compounds, but paint may not be used as a sealant.
Performance and/or design Contaminant and operating standard

Leachability of the hazardous

None. contaminants must be reduced. restrictions ${ }^{2}$
Sealing must avoid exposure of the debris surface to potential leaching media and sealant must be resistant to degradation by the debris and its contaminants and materials into which it may come into contact after placement (leachate, other waste, microbes).

None.

None.

'Hazardous debris must be treated by either these standards or the waste-specific treatment standards for the waste contaminating the debris. The treatment standards must be met for each type of debris contained in a mixture of debris types, unless the debris is converted into treatment residue as a result of the treatment process. Debris treatment residuals are subject to the waste-specific treatment standards for the waste contaminating the debris.

${ }^{2}$ Contaminant restriction means that the technology is not BDAT for that contaminant. If debris containing a restricted contaminant is treated by the technology, the contaminant must be subsequently treated by a technology for which it is not restricted in order to be land disposed (and excluded from Subtitle C regulation).

"Clean debris surface" means the surface, when viewed without magnification, shall be free of all visible contaminated soil and hazardous waste except that residual staining from soil and waste consisting of light shadows, slight streaks, or minor discolorations, and soil and waste in cracks, crevices, and pits may be present provided that such staining and waste and soil in cracks, crevices, and pits shall be limited to no more than $5 \%$ of each square inch of surface area. 
Technology description
Performance and/or design and operating standard
Contaminant restrictions ${ }^{2}$

4Acids, solvents, and chemical reagents may react with some debris and contaminants to form hazardous compounds. For example, acid washing of cyanide-contaminated debris could result in the formation of hydrogen cyanide. Some acids may also react violently with some debris and contaminants, depending on the concentration of the acid and the type of debris and contaminants. Debris treaters should refer to the safety precautions specified in Material Safety Data Sheets for various acids to avoid applying an incompatible acid to a particular debris/contaminant combination. For example, concentrated sulfuric acid may react violently with certain organic compounds, such as acrylonitrile.

If reducing the particle size of debris to meet the treatment standards results in material that no longer meets the $60-\mathrm{mm}$ minimum particle size limit for debris, such material is subject to the waste-specific treatment standards for the waste contaminating the material, unless the debris has been cleaned and separated from contaminated soil and waste prior to size reduction. At a minimum, simple physical or mechanical means must be used to provide such cleaning and separation of nondebris materials to ensure that the debris surface is free of caked soil, waste, or other nondebris material.

The demonstration "Equivalent Technology" under \$268.42(b) must document that the technology treats containinants subject to treatment to a level equivalent to that required by the performance and design and operating standards for other technologies in this table such that residual levels of hazardous contaminants will not pose a hazard to human health and the environment without management controls.

'Dioxin-listed wastes are EPA Hazardous Waste numbers FO20, FO21, FO22, FO23, F026, and F027.

'Any soil, waste, and other nondebris material that remains on the debris surface (or remains mixed with the debris) after treatment is considered a treatment residual that must be separated from the debris using, at a minimum, simple physical or mechanical means. Examples of simple physical or mechanical means are vibratory or trommel screening or water washing. The debris surface need not be cleaned to a "clean debris surface" as defined in note 3 when separating treated debris from residue; rather, the surface must be free of caked soil, waste, or other nondebris material. Treatment residuals are subject to the waste-specific treatment standards for the waste contaminating the debris.

Thermal desorption is distinguished from thermal destruction in that the primary purpose of thermal desorption is to volatilize contaminants and to remove them from the treatment chamber for subsequent destruction or other treatment.

Source: 57 FR 37277. 


\section{INTERNAL DISTRIBUTION}

1. M. R. Ally

2-6. T. J. Abraham

7-8. P. M. Backus

9-10. M. L. Baker

11. C. E. Benson

12-13. J. B. Berry

14. A. Bleier

15. G. F. Boris

16. W. D. Bostick

17. C. H. Brown, Jr.

18. C. E. Buttram

19. C. M. Cecala

20-31. T. B. Conley

32. A. G. Croff

33. L. R. Dole

34. T. L. Donaldson

35. P. A. Flowers

36. C. L. Francis

37. C. E. Frye

38. V. P. Gilbert

39-48. T. M. Gilliam

49. J. Gilpin

50. H. W. Godbee

51. A. H. Gorin

52. J. R. Hightower

53-57. D. A. Hutchins

58. T. E. Kent

59. R. R. Kimmitt

60. R. H. Krabill

61. D. K. Little

62. A. P. Malinauskas
63. A. J. Mattus

64-68. C. H. Mattus

69. E. W. McDaniel

70. W. S. McGarvey

71. L. E. McNeese

72. L. J. Mezga

73. I. L. Morgan

74. M. I. Morris

75. C. M. Noakes

76. I. W. Osborne-Lee

77. J. J. Perona

78. S. M. Robinson

79. M. M. Roe

80. T. O. Rogers

81. R. J. Sams

82. D. P. Schaefferkoetter

83. J. W. Snider

84. R. D. Spence

85. L. H. Stinton

86. T. N. Ternes

87. D. R. Trotter

88. H. P. Wayland, Jr.

89. D. D. West

90. J. E. Williams

91. B. V. Wojtowicz

92. Central Research Library

93. ORNL Y-12 Technical Library, Document Reference Section

94. Laboratory Records-RC

95-96. Laboratory Records

97. ORNL Patent Section

\section{EXTERNAL DISTRIBUTION}

98. Ed S. Alperin, IT Corporation, 312 Directors Drive, Knoxville, TN 37923

99. S. J. Astoria, Gilbert Commonwealth, 1055 Commerce Park Drive, Suite 200, Oak Ridge, TN 37830

100. Bill Batchelor, Texas A\&M University, Dept. of Civil Engineering, College Station, TX 77803

101. L. D. Eyman, Director, Waste Policy Institute, 1900 Kraft Dr., Blacksburg, VA 20060

102. Larry W. Jones, Univ. of Tennessee, Waste Management Inst., 428 S. Stadium Hall, Knoxville, TN 37996-0710 
103. R. W. Morrow, Gilbert Commonwealth, 1055 Commerce Park Drive, Suite 200, Oak Ridge, TN 37830

104. Ian L. Pegg, Vitreous State Laboratory, Hannan Hall, 620 Michigan Avenue, NE, Washington, DC 20064

105-106. Bob Petersen, EET, 129-A Perimeter Park Road, Knoxville, TN 37922

107. Barry E. Scheetz, Pennsylvania State University, Materials Research Lab., University Park, PA 16802

108. Julia A. Stegemann, Wastewater Technology Centre, P.O. Box 5068, Burlingion, Ontario L7R-4L7, Canada

109-110. Office of Scientific and Technical Information, P.O. Box 62,Oak Ridge, TN 37831

111. Office of Assistant Manager, Energy Research and Development, DOE-ORO, P.O. Box 2001, Oak Ridge, TN 37831

\section{OTHER FEDERAL AGENCIES}

112. J. J. Barich, U.S. Environmental Protection Agency, 1200 Sixth Avenue, Seattle, WA 98101

113. John M. Cullinane, Jr., USACE Waterways Experiment Station, 3909 Halls Ferry Road, Vicksburg, MS 39180-6199

114. Patricia Erickson, U.S. Environmental Protection Agency, 26 W. Martin Luther King Drive, Cincinnati, OH 45268

115. T. T. Holmes, U.S. Army Corps of Engineers, Waterways Experiment Station, P.O. Box 631, Vicksburg, MS 39180

116. Michael Tokar, U.S. Nuclear Regulatory Commission, Office of Nuclear Material Safety and Safeguards, Washington, DC 20555

117. Dr. Lillian D. Wakeley, USAE Waterways Experiment Station, 3909 Halls Ferry Rd., Vicksburg, MS 39180-6199

\section{OTHER M\&O CONTRACTORS}

118. Catherine M. Anderson, Battelle, Pacific Northwest Laboratories, Battelle Boulevard, Richland, WA 99352

119. Dan Armstrong, Westinghouse, Savannah River Plant, Aiken, SC 29802

120. Larry Bagaasen, Rocky Flats Plant, P.O. Box 928, Golden, CO 80402-0464

121. Chuck Baldwin, EG\&G-Rocky Flats Plant, P.O. Box 928, Golden, CO 80402-0464

122. J. Bradford, EG\&G Idaho, Inc., P.O. Box 1625, Idaho Falls, ID 83415-2109

123. Harcourt Bull III, Westinghouse, 704Z, Savannah River Plant, Aiken, SC 29802

124. Ken Burgard, Westinghouse, P.O. Box 1970, MS-R4-03, Richland, WA 99352

125. Wu-Ching Cheng, Sandia National Laboratory, P.O. Box 5800, Albuquerque, NM 87185-5800

126. Peter Colombo, Brookhaven National Laboratory, 50 Rutherford, Bldg. 703, Upton, NY 11973

127. Mel Cowgill, Brookhaven National Laboratory, Bldg. 830, Upton, NY 11973

128. G. Ross Darnell, EG\&G Idaho, Inc., P.O. Box 1625, MS-2424, Idaho Falls, ID 83415-2424

129. J. L. Epstein, Westinghouse Hanford Company, P.O. Box 1970, Richland, WA 99352

130. Andrea Faucette, Rocky Flats Plant, P.O. Box 928, Golden, CO 80402-0464

131. E. C. Garcia, EG\&G, P.O. Box 1625, Idaho Falls, ID 83415 
133. John H. Heiser, Brookhaven National Laboratory, 50 Rutherford, Bldg. 703, Upton, NY 11973-5000

134. Carol Jantzen, Westinghouse Savannah River Company, P.O. Box 616, Aiken, SC 29802

135. C. L. Jensen, EG\&G, Bldg. 776, Golden, CO 80402-0464

136. Paul D. Kalb, Brookhaven National Laboratory, Env. \& Waste Tech. Center, Bldg. 830, Upton, NY 11973

137. Richard Kent Farnsworth, EG\&G Idaho, Inc., Office of Waste Tech. Develop., P.O. Box 1625, Idaho Falls, ID 83415-3710

138. C. A. Langton, Westinghouse Savannah River Company, P.O. Box 616, Aiken, SC 29802

139. J. W. Liskowitz, Institute for Hazardous and Toxic Waste Management, New Jersey Institute of Technology, Newark, NJ 07102

140. R. O. Lokken, Battelle, Pacific Northwest Laboratories, Battelle Boulevard, Richland, WA 99352

141. John W. Mandler, INEL, P.O. Box 1625, Idaho Falls, ID 83415

142. Charles E. McDonald, Westinghouse Hanford Company, P.O. Box 1970, MS H1-60, Richland, WA 99352

143. M. A. Mihalic, Westinghouse-Hanford, Box 1970, L4-88, Richland, WA 99352

144. Dean Nester, Westinghouse, P.O. Box 1970, Richland, WA 99352

145. Paul Pak, USDOE-Richland Operations Office, Environmental Restoration Div., MS-85-19, Richland, WA 99352

146. Thomas R. Pauly, Hanford, P.O. Box 1970, Richland, WA 99352

147. Richard Peters, Battelle, Pacific Northwest Laboratories, Battelle Boulevard, Richland, WA 99352

148. John Pickett, Savannah River Site, Bldg. 730-M, P.O. Box 616, Aiken, SC 29801

149. Gregory F. Piepel, Battelle, Pacific Northwest Laboratories, Battelle Boulevard, Richland, WA 99352

150. N. R. Quick, EG\&G, P.O. Box 464, Bldg. 881, Golden, CO 80402

151. S. K Rutherford, Westinghouse Envirnnmental Management Company of Ohio, P.O. Box 398704, Cincinnati, OH 45239-8704

152. Barry Siskind, Brookhaven National Laboratory, Bldg. 8?.., Upton, NY 11973

153. Peter Soo, Brookhaven National Laboratory, Bldg. 83C. Upton, NY 11973

154. Dennis Thompson, Savannah River Plant, Bldg. 704Z, Aiken SC 29802

155. G. W. Veazey, Los Alamos National Laboratory, P.O. Box 1663, MS E524, Los Alamos, NM 87545

156. J. A. Voogd, Westinghouse Hanford Company, P.O. Box 1970, Richland, WA 99352

157. John Veil, Argonne National Laboratory, 370 L'Enfant Promenade, Suite 702, Washington, DC 20024

158. T. G. Weiss, WB\&S, West Valley Nuclear Services, P.O. Box 191, West Valley, NY 14171

159. F. R. Weitz, Savannah River Laboratory, P.O. Box 616, Aiken, SC 29801

160. Michelle Wells, Savannah River Plant, Bldg. 704Z, Aiken, SC 29802

161. Carlton C. Wiles, National Research Energy Laboratory, Industrial Technologies Division, 1617 Cole Boulevard, Golden, CO 80401-3393 

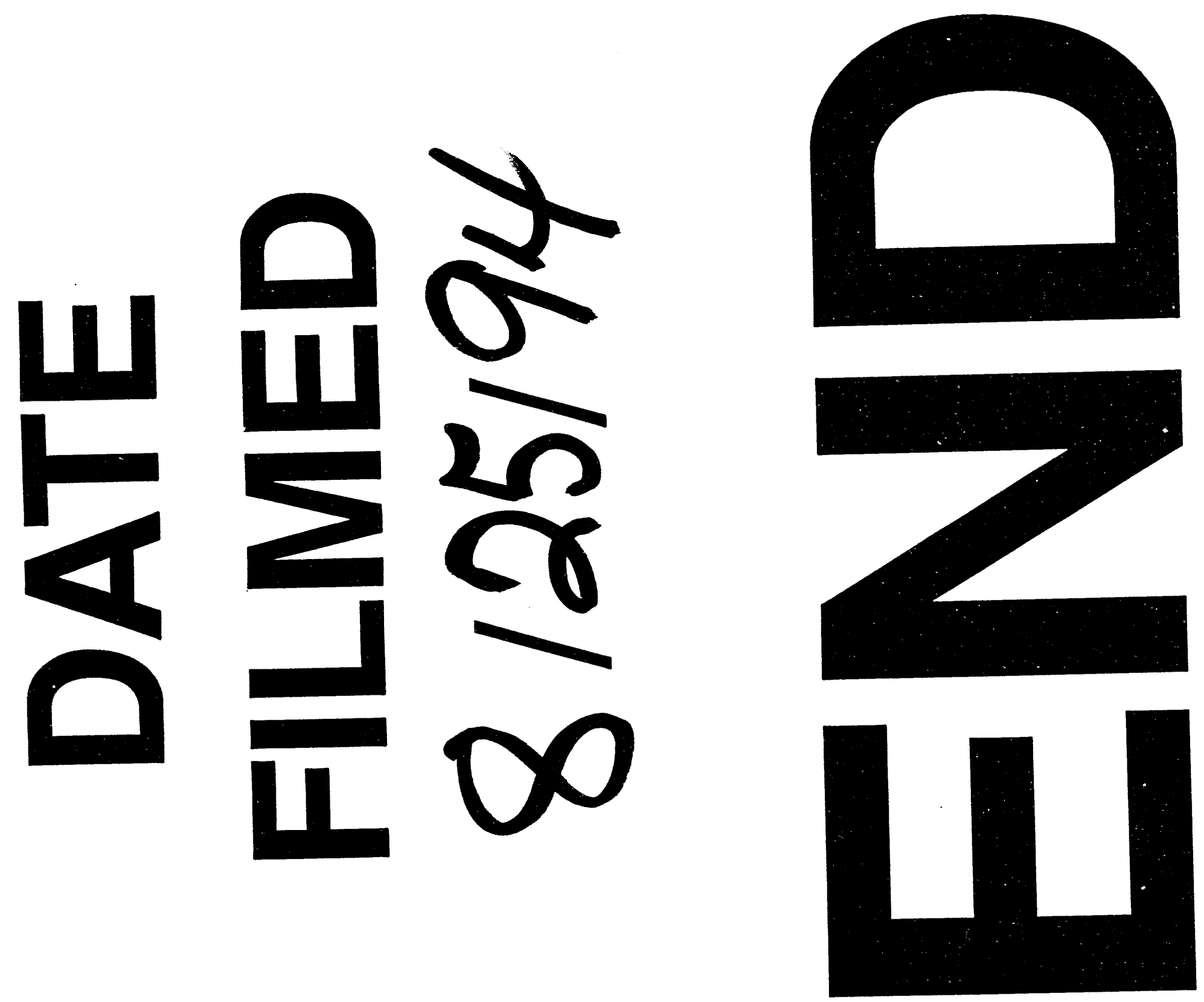
